Supporting information for:

\title{
Use of the Nascent Isocyclic Ring to Anchor Assembly of the Full Skeleton of Model Chlorophylls
}

\author{
Pengzhi Wang, Futai Lu, and Jonathan S. Lindsey* \\ Department of Chemistry \\ North Carolina State University \\ Raleigh, NC 27695-8204 \\ e-mail: jlindsey@ncsu.edu
}

\section{Table of Contents}

\section{Topic}

1. Additional investigation of reaction conditions

Page Number

2. Absorption and fluorescence spectra

$\mathrm{S} 2$

3. Single-crystal X-ray structures

S9

4. IR spectra

5. 2D NOESY spectrum

S24

6. Calculated conformations and distance measurements

7. ${ }^{1} \mathrm{H}$ NMR and ${ }^{13} \mathrm{C}$ NMR spectra 


\section{Additional investigation of reaction conditions}

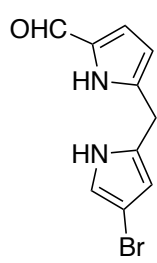

1

(1)

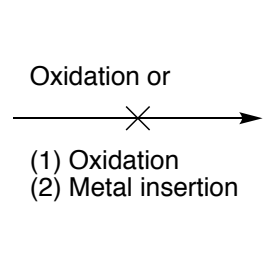

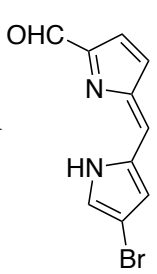

S1

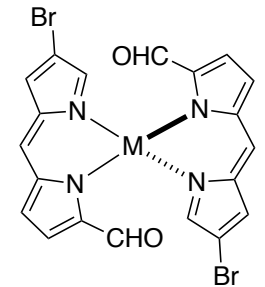

S2

Table S1. Investigation of conditions for formation of dipyrrin (S1) or bis(dipyrrinato)metal complex (S2).

\begin{tabular}{|c|c|c|c|c|c|}
\hline Entry & $1(\mathrm{mM})$ & $\begin{array}{c}\text { Additive }^{a} \text { and Reaction } \\
\text { time }\end{array}$ & Solvent & $\mathrm{T} /{ }^{\circ} \mathrm{C}$ & Results \\
\hline 1 & 8 & DDQ, 10 min & $\mathrm{CH}_{2} \mathrm{Cl}_{2}$ & $\mathrm{rt}$ & $-^{b}$ \\
\hline 2 & 8 & $\mathrm{DDQ}, 40 \mathrm{~min}$ & $\mathrm{CH}_{2} \mathrm{Cl}_{2}$ & $\mathrm{rt}$ & $-^{b}$ \\
\hline 3 & 8 & $\mathrm{DDQ}, 40 \mathrm{~min}$ & DMF & $\mathrm{rt}$ & $-^{b}$ \\
\hline 4 & 8 & $\mathrm{DDQ}, 40 \mathrm{~min}$ & $\mathrm{THF}$ & $\mathrm{rt}$ & $-b$ \\
\hline 5 & 8 & $\mathrm{DDQ}, 40 \mathrm{~min}$ & $\mathrm{CHCl}_{3}$ & $\mathrm{rt}$ & $-{ }^{b, c}$ \\
\hline 6 & 8 & $p$-Chloranil, $26 \mathrm{~h}$ & $\mathrm{CH}_{2} \mathrm{Cl}_{2}$ & $\mathrm{rt}$ & $-{ }^{b, c}$ \\
\hline 7 & 80 & $\begin{array}{l}\mathrm{DDQ}, 40 \text { min, then } \\
\mathrm{Zn}(\mathrm{OAc})_{2}(1.3 \text { equiv })\end{array}$ & $\mathrm{CH}_{2} \mathrm{Cl}_{2}$ & $\mathrm{rt}$ & $-^{b, c}$ \\
\hline 8 & 80 & $\begin{array}{l}\mathrm{DDQ}, 40 \mathrm{~min}, \text { then } \\
\mathrm{Zn}(\mathrm{OAc})_{2}(1.3 \text { equiv })\end{array}$ & THF & $\mathrm{rt}$ & $-b, c$ \\
\hline 9 & 80 & $\begin{array}{l}\mathrm{DDQ}, 40 \text { min, then } \\
\mathrm{Zn}(\mathrm{OAc})_{2}(1.3 \text { equiv })\end{array}$ & $\mathrm{CHCl}_{3}$ & $\mathrm{rt}$ & $b^{b, c}$ \\
\hline 10 & 80 & $\begin{array}{l}\mathrm{DDQ}, \mathrm{Zn}(\mathrm{OAc})_{2}(2.0 \\
\text { equiv }), 24 \mathrm{~h}\end{array}$ & THF & $\mathrm{rt}$ & $\begin{array}{c}\lambda_{\mathrm{abs}}=502, \\
523 \mathrm{~nm}, 5 \% \\
\text { yield }\end{array}$ \\
\hline 11 & 80 & $\begin{array}{l}\mathrm{DDQ}, \mathrm{Cu}(\mathrm{OAc})_{2}(2.0 \\
\text { equiv }), 24 \mathrm{~h}\end{array}$ & THF & $\mathrm{rt}$ & Trace $^{b, d}$ \\
\hline 12 & 8 & $\begin{array}{l}\mathrm{DDQ}, \mathrm{Pd}(\mathrm{OAc})_{2}(1.0 \\
\text { equiv }), \text { overnight }\end{array}$ & THF & $\mathrm{rt}$ & $-{ }^{b}$ \\
\hline 13 & 8 & $\begin{array}{c}\mathrm{DDQ}, \mathrm{PdBr}_{2}(1.0 \text { equiv }), \\
\text { overnight }\end{array}$ & THF & $\mathrm{rt}$ & $-{ }^{b}$ \\
\hline 14 & 8 & $\begin{array}{c}\mathrm{DDQ}, \mathrm{Pd}_{2}(\mathrm{dba})_{3}(1.0 \\
\text { equiv }), \text { overnight }\end{array}$ & THF & $\mathrm{rt}$ & $-{ }^{b}$ \\
\hline 15 & 8 & $\begin{array}{l}\mathrm{DDQ}, \mathrm{Pd}_{2}(\mathrm{dba})_{3}(0.5 \\
\text { equiv }) \text {, overnight }\end{array}$ & Methanol & $\mathrm{rt} / 0^{\circ} \mathrm{C} / 60^{\circ} \mathrm{C}$ & $-{ }^{b}$ \\
\hline 16 & 8 & $\begin{array}{c}\mathrm{DDQ}, \mathrm{Pd}_{2}(\mathrm{dba})_{3}(2.5 \\
\text { equiv }), \text { overnight }\end{array}$ & $\mathrm{CH}_{2} \mathrm{Cl}_{2}$ & $\mathrm{rt} / 0^{\circ} \mathrm{C} / 60^{\circ} \mathrm{C}$ & $-{ }^{b}$ \\
\hline 17 & 8 & $\mathrm{DDQ}, \mathrm{Pd}_{2}(\mathrm{dba})_{3}(2.5$ & $\mathrm{CHCl}_{3}$ & $\mathrm{rt} / 0^{\circ} \mathrm{C} / 60^{\circ} \mathrm{C}$ & $-b$ \\
\hline
\end{tabular}


equiv), overnight

$18 \quad 8 \quad$ DDQ, $\mathrm{Pd}_{2}(\mathrm{dba})_{3}(2.5$ equiv), overnight

Methanol $/ \mathrm{CHCl}_{3} / \mathrm{TEA} \quad \mathrm{rt} / 0^{\circ} \mathrm{C} / 60^{\circ} \mathrm{C} \quad-^{b}$ (1:1:0.5)

19

DDQ, NaH (excess),

Methanol $/ \mathrm{CHCl}_{3} / \mathrm{TEA}$

$\mathrm{rt}$

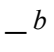

$\mathrm{Pd}_{2}(\mathrm{dba})_{3}(2.5$ equiv),

$(1: 1: 0.5)$

overnight

20

8

DDQ (4.0 equiv), $\mathrm{Pd}_{2}(\mathrm{dba})_{3}(2.5$ equiv), overnight

$218 \quad$ DDQ (4.0 equiv), $\mathrm{NaH}$ (excess), $\mathrm{Pd}_{2}(\mathrm{dba})_{3}(2.5$ equiv), overnight

\begin{tabular}{|c|c|}
\hline $\begin{array}{c}\text { Methanol/ } / \mathrm{CHCl}_{3} / \mathrm{TEA} \\
(1: 1: 0.5)\end{array}$ & $\mathrm{rt}$ \\
\hline $\begin{array}{c}\text { Methanol/ } / \mathrm{CHCl}_{3} / \mathrm{TEA} \\
(1: 1: 0.5)\end{array}$ & $\mathrm{rt}$ \\
\hline
\end{tabular}

${ }^{a}$ The oxidizing reagent DDQ is 1.0 equiv unless noted otherwise. ${ }^{b}$ Monitored by TLC and UVVis absorption spectroscopy every 15 min for the first $3 \mathrm{~h} .{ }^{c}$ Chromatographed but no desired product was obtained. ${ }^{d} \mathrm{~A}$ small amount of product was detected by UV-Vis absorption spectroscopy, but a yield was not determined. 


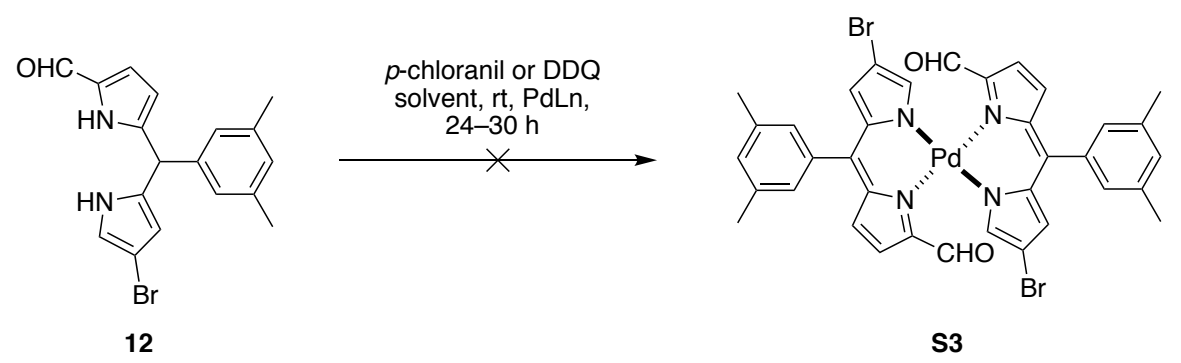

Table S2. Investigation of conditions for formation of bis(dipyrrinato)metal complex (S3).

\begin{tabular}{|c|c|c|c|}
\hline Entry & 12 & Condition & Results $^{a}$ \\
\hline 1 & $5 \mathrm{mg}$ & $\begin{array}{c}p \text {-Chloranil ( }(1.0 \text { equiv), } \\
\mathrm{CHCl}_{3} / \mathrm{Methanol} / \mathrm{TEA}(4: 2: 1), \mathrm{Pd}_{2}(\mathrm{dba})_{3} \\
\text { ( } 0.25 \text { equiv), } 24 \mathrm{~h}, \mathrm{rt}\end{array}$ & $\begin{array}{l}\text { Crude product: } \lambda_{\max }=325 \\
\text { (broad), } 406(\text { small }) \mathrm{nm} .\end{array}$ \\
\hline 2 & $5 \mathrm{mg}$ & $\begin{array}{c}p \text {-Chloranil ( } 1.0 \text { equiv }) \\
\mathrm{CHCl}_{3} / \text { Methanol/TEA }(4: 2: 1), \\
\operatorname{Pd}(\mathrm{OAc})_{2}(0.5 \text { equiv }), 24 \mathrm{~h}, \mathrm{rt}\end{array}$ & $\begin{array}{l}\text { Crude product: } \lambda_{\max }=305 \\
\text { (broad), } 409 \text { (small) } \mathrm{nm} .\end{array}$ \\
\hline 3 & $15 \mathrm{mg}$ & $\begin{array}{c}p \text {-Chloranil (1.0 equiv), } \\
\mathrm{CHCl}_{3} / \mathrm{Methanol} / \mathrm{TEA}(4: 2: 1), \mathrm{Pd}_{2}(\mathrm{dba})_{3} \\
(0.25 \text { equiv }), 24 \mathrm{~h}, \mathrm{rt}, \\
\text { air or under argon }\end{array}$ & $\begin{array}{c}\text { Chromatographed [silica, } \\
\mathrm{CH}_{2} \mathrm{Cl}_{2} \text { ] to afford a pink band } \\
\lambda_{\max }=230,410 \text { (sharp) nm; blue } \\
\text { band } \lambda \text { max }=313,409 \mathrm{~nm},{ }^{1} \mathrm{H} \\
\text { NMR showed a proton peak at } 5 \text { - } \\
\text { position around } 4.2 \mathrm{ppm} .\end{array}$ \\
\hline 4 & $15 \mathrm{mg}$ & $\begin{array}{c}p \text {-Chloranil ( } 1.0 \text { equiv), } \\
\mathrm{CHCl}_{3} / \text { Methanol/TEA }(4: 2: 1), \\
\operatorname{Pd}(\mathrm{OAc})_{2}(0.25 \text { equiv }), 24 \mathrm{~h}, \mathrm{rt}\end{array}$ & Similar to entry 3 . \\
\hline 5 & $20 \mathrm{mg}$ & $\begin{array}{c}\text { (1) } p \text {-Chloranil (1.2 equiv) THF, } 24 \mathrm{~h}, \mathrm{rt} \\
\text { (2) } \mathrm{Pd}(\mathrm{OAc})_{2} \text { ( } 0.5 \text { equiv) in } \mathrm{CH}_{2} \mathrm{Cl}_{2} \text { or } \\
\mathrm{CHCl}_{3} \text {, overnight, } \mathrm{rt}\end{array}$ & $\begin{array}{c}\text { Chromatographed [silica, } \\
\mathrm{CH}_{2} \mathrm{Cl}_{2} \text { ] to afford orange band } \\
\lambda_{\max }=292,419,523 \text { (small) } \mathrm{nm} ; \\
\text { dark-orange band: } 309,416,518 \\
\mathrm{~nm} .\end{array}$ \\
\hline 6 & $5 \mathrm{mg}$ & $\begin{array}{c}\text { DDQ (1.0 equiv), } \mathrm{CHCl}_{3} / \mathrm{Methanol} / \mathrm{TEA} \\
(4: 2: 1), \mathrm{Pd}_{2}(\mathrm{dba})_{3}(0.25 \text { equiv }), 40 \mathrm{~min} \\
\mathrm{rt}\end{array}$ & Crude product: $\lambda_{\max }=420 \mathrm{~nm}$ \\
\hline 7 & $20 \mathrm{mg}$ & DDQ (1.0 equiv), THF, rt, $3 \mathrm{~h}$ & $\begin{array}{l}\text { Chromatographed [silica, } \mathrm{CHCl}_{3} \text { ] } \\
\text { to afford orange band } \lambda_{\max }=270, \\
300,436 \mathrm{~nm} \text {; green band } \lambda_{\max }= \\
272,419 \mathrm{~nm}\end{array}$ \\
\hline 8 & $5 \mathrm{mg}$ & $\begin{array}{l}\text { DDQ (1.0 equiv), } \mathrm{CHCl}_{3} / \mathrm{Methanol} / \mathrm{TEA} \\
(4: 2: 1), \mathrm{Pd}(\mathrm{OAc})_{2}(0.5 \text { equiv), } 40 \mathrm{~min}, \mathrm{rt}\end{array}$ & Similar to entry 6. \\
\hline
\end{tabular}

${ }^{a}$ TLC showed all starting materials were consumed. MALDI-MS showed no dipyrrin, bis(dipyrrinato)palladium or palladium-porphyrin complexes. 


\section{Procedures for screening reaction conditions for formation of the chlorophyll skeleton}

Procedure for screening conditions. Considering a reaction with $0.2 \mathrm{mM}$ concentration and $1 \mathrm{~mL}$ reaction volume, the requisite amount of $\mathbf{2 0}$ is $2 \times 10^{-7} \mathrm{~mol}(\sim 0.122 \mathrm{mg})$. The quantity of most acids was tentatively assigned as 10 equiv. A sample of $4.9 \mathrm{mg}\left(3.0 \times 10^{-6} \mathrm{~mol}\right)$ of $\mathbf{2 0}$ was dissolved in $10 \mathrm{~mL}$ of dichloromethane to create a stock solution. Each $250 \mu \mathrm{L}$ aliquot of the stock solution contains $0.12 \mathrm{mg}$ of $\mathbf{2 0}$.

Reaction setup procedure: (1) An aliquot of $250 \mu \mathrm{L}$ of the stock solution was transferred via a micropipet into a small reaction vial. (2) The stock solution was taken to dryness with a gentle stream of argon. (3) The appropriate reaction solvent (1 mL) was added. (4) The desired acid and any additives (e.g., DTBP) were added in appropriate stock solutions. (5) The solvent line on the vial was marked to guard against and subsequent correct for solvent loss on prolonged and/or heated reaction. (6) The vial was subjected to the requisite temperature. (7) Solvent was resupplied during the reaction if a loss of solvent was observed.

Reaction-monitoring procedure. If we assume $0.5 \%$ as the yield lower bound for detectability, considering that a chlorin usually has a $\mathrm{Q}_{\mathrm{y}}$ band molar absorption coefficient of about $34,000 \mathrm{M}^{-1} \mathrm{~cm}^{-1}$, the sample should give a $\mathrm{Q}_{\mathrm{y}}$ band absorbance of $0.5 \% \times 34,000 \mathrm{M}^{-1} \mathrm{~cm}^{-1}$ $\times 0.2 \mathrm{mM} \times 1 \mathrm{~cm}=0.034$ in a typical cuvette $(1 \mathrm{~cm}$ pathlength $)$. While a typical noise peak in an absorption spectrum usually has a height of up to around 0.004 , this absorbance will give a signal/noise of about 17 . For a cuvette $(1.0 \mathrm{~cm}$ width $)$ with a capacity of about $1.5 \mathrm{~mL}$, a measurement is readily achieved with a volume of $1.0 \mathrm{~mL}$. Such a result can give a reasonably reliable estimation for the yield; however, further dilution of the reaction sample $(1 \mathrm{~mL})$ for the measurement may not be possible. Thus, we generally took the full amount of undiluted reaction solution into the cuvette for the measurement, with the addition of $\mathrm{Et}_{3} \mathrm{~N}$ if no base (DTBP) was present to neutralize any potential protonated species.

Considering the small amount of acid/DTBP for the reaction, in some cases the stock solution in the corresponding solvent needs to be prepared first, and the acid was added accordingly. Take TMSOTf/DTBP condition as an example. The required amounts are $0.44 \mathrm{mg}$ and $1.53 \mathrm{mg}$, respectively. Thus, a stock solution for 20 experiments requires the following: Dissolve $8.8 \mathrm{mg}$ of TMSOTf and $30.6 \mathrm{mg}$ of DTBP into $20 \mathrm{~mL}$ of solvent. 
Table S3. Investigation of conditions for formation of chlorin 22 from compound $19{ }^{a}$

\begin{tabular}{|c|c|c|c|c|}
\hline Entry & Lewis acid $^{b}$ and Additive & Solvent & Temperature $\left({ }^{\circ} \mathrm{C}\right)$ & Yield $^{c}$ \\
\hline 1 & $\mathrm{Sc}(\mathrm{OTf})_{3}$ & $\mathrm{CH}_{3} \mathrm{CN}$ & $\mathrm{rt} / 80$ & $-e^{e, f /-e, f}$ \\
\hline 2 & $\mathrm{Co}(\mathrm{OAc})_{2}$ & $\mathrm{CH}_{3} \mathrm{CN}$ & $\mathrm{rt} / 80$ & $-e, f /-e, f$ \\
\hline 3 & $\mathrm{NiCl}_{2}$ & $\mathrm{CH}_{3} \mathrm{CN}$ & $\mathrm{rt} / 80$ & $-e, f /-e, f$ \\
\hline 4 & $\mathrm{Ni}(\mathrm{OTf})_{2}$ & $\mathrm{CH}_{3} \mathrm{CN}$ & $\mathrm{rt} / 80$ & $-e, f /-e, f$ \\
\hline 5 & $\mathrm{Cu}(\mathrm{OTf})_{2}$ & $\mathrm{CH}_{3} \mathrm{CN}$ & $\mathrm{rt} / 80$ & $-e, f /-e, f$ \\
\hline 6 & $\mathrm{Yb}(\mathrm{OTf})_{3}$ & $\mathrm{CH}_{3} \mathrm{CN}$ & $\mathrm{rt} / 80$ & $-e, f /-e, f$ \\
\hline 7 & $\mathrm{InCl}_{3}$ & $\mathrm{CH}_{3} \mathrm{CN}$ & $\mathrm{rt} / 80$ & $-{ }^{e, f} /$ Trace \\
\hline 8 & $\mathrm{InBr}_{3}$ & $\mathrm{CH}_{3} \mathrm{CN}$ & $\mathrm{rt} / 80$ & Trace/Trace \\
\hline 9 & $\operatorname{In}(\mathrm{OTf})_{3}$ & $\mathrm{CH}_{3} \mathrm{CN}$ & $\mathrm{rt} / 80$ & $-e, f /-e, f$ \\
\hline 10 & $\operatorname{In}(\mathrm{OAc})_{3}$ & $\mathrm{CH}_{3} \mathrm{CN}$ & $\mathrm{rt} / 80$ & $-e, g /-e, f$ \\
\hline 11 & $\mathrm{Hf}(\mathrm{OTf})_{3}$ & $\mathrm{CH}_{3} \mathrm{CN}$ & $\mathrm{rt} / 80$ & $-e, f /-e, f$ \\
\hline 12 & $\mathrm{Bi}(\mathrm{OTf})_{3}$ & $\mathrm{CH}_{3} \mathrm{CN}$ & $\mathrm{rt} / 80$ & $-e, f /-e, f$ \\
\hline 13 & $\mathrm{CeI}_{3}$ & $\mathrm{CH}_{3} \mathrm{CN}$ & $\mathrm{rt} / 80$ & $-e, f /-e, f$ \\
\hline 14 & $\mathrm{Sc}(\mathrm{OTf})_{3} / \mathrm{Zn}(\mathrm{OAc})_{2}$ & $\mathrm{CH}_{3} \mathrm{CN}$ & $\mathrm{rt} / 80$ & Trace/- $e, f$ \\
\hline 15 & $\mathrm{Ni}(\mathrm{OTf})_{2} / \mathrm{NiCl}_{2}$ & $\mathrm{CH}_{3} \mathrm{CN}$ & $\mathrm{rt} / 80$ & $-e, g /-e, f$ \\
\hline 16 & $\mathrm{Yb}(\mathrm{OTf})_{3} / \mathrm{Zn}(\mathrm{OAc})_{2}$ & $\mathrm{CH}_{3} \mathrm{CN}$ & $\mathrm{rt} / 80$ & ${ }_{-e, f / \text { Trace }}$ \\
\hline 17 & $\mathrm{Yb}(\mathrm{OTf})_{3} / \mathrm{Co}(\mathrm{OAc})_{2}$ & $\mathrm{CH}_{3} \mathrm{CN}$ & $\mathrm{rt} / 80$ & $-e, f /-e, f$ \\
\hline 18 & $\mathrm{In}(\mathrm{OAc})_{3} / \mathrm{InCl}_{3}$ & $\mathrm{CH}_{3} \mathrm{CN}$ & $\mathrm{rt} / 80$ & ${ }_{-}^{e, f} /$ Trace \\
\hline 19 & $\operatorname{In}(\mathrm{OAc})_{3} / \operatorname{In}(\mathrm{OTf})_{3}$ & $\mathrm{CH}_{3} \mathrm{CN}$ & $\mathrm{rt} / 80$ & Trace/Trace \\
\hline 20 & $\operatorname{In}(\mathrm{OTf})_{3} / \mathrm{InCl}_{3}$ & $\mathrm{CH}_{3} \mathrm{CN}$ & $\mathrm{rt} / 80$ & $-e, f / 8.2 \%$ \\
\hline 21 & $\operatorname{In}(\mathrm{OTf})_{3} / \mathrm{InBr}_{3}$ & $\mathrm{CH}_{3} \mathrm{CN}$ & $\mathrm{rt} / 80$ & $-{ }_{-e, f} /$ Trace \\
\hline $22^{h}$ & $\mathrm{In}(\mathrm{OTf})_{3} / \mathrm{InCl}_{3}(40 / 40$ equiv) & $\mathrm{CH}_{3} \mathrm{CN}$ & $\mathrm{rt} / 80$ & Trace $/ 7.8 \%$ \\
\hline $23^{h}$ & $\begin{array}{c}\operatorname{In}(\mathrm{OTf})_{3} / \mathrm{InCl}_{3}(100 / 100 \\
\text { equiv })\end{array}$ & $\mathrm{CH}_{3} \mathrm{CN}$ & $\mathrm{rt} / 80$ & Trace $/ 1.9 \%$ \\
\hline $24^{i}$ & $\operatorname{In}(\mathrm{OTf})_{3} / \mathrm{InCl}_{3}$ & $\mathrm{CH}_{3} \mathrm{CN}$ & $\mathrm{rt} / 80$ & Trace $/ 1.9 \%$ \\
\hline $25^{j}$ & $\mathrm{In}(\mathrm{OTf})_{3} / \mathrm{InCl}_{3}$ & $\mathrm{CH}_{3} \mathrm{CN}$ & $\mathrm{rt} / 80$ & $-e, f /-e, f$ \\
\hline 26 & $\operatorname{In}(\mathrm{OTf})_{3} / \mathrm{InCl}_{3}$ & DCE & 65 & $-e, f /-d$ \\
\hline 27 & $\operatorname{In}(\mathrm{OTf})_{3} / \mathrm{InCl}_{3}$ & Toluene & 100 & $-e, f /-e, f$ \\
\hline 28 & $\mathrm{InBr}_{3} / \mathrm{In}(\mathrm{OTf})_{3}$ & $\mathrm{CH}_{3} \mathrm{CN}$ & $\mathrm{rt} / 80$ & $-{ }_{-e, f} /$ Trace \\
\hline 29 & $\mathrm{Hf}(\mathrm{OTf})_{3} / \mathrm{Zn}(\mathrm{OAc})_{2}$ & $\mathrm{CH}_{3} \mathrm{CN}$ & $\mathrm{rt} / 80$ & $-e, f /-e, f$ \\
\hline 30 & $\mathrm{Bi}(\mathrm{OTf})_{3} / \mathrm{InCl}_{3}$ & $\mathrm{CH}_{3} \mathrm{CN}$ & $\mathrm{rt} / 80$ & $\_e, f /-e, f$ \\
\hline 31 & $\mathrm{CeI}_{3} / \mathrm{InCl}_{3}$ & $\mathrm{CH}_{3} \mathrm{CN}$ & $\mathrm{rt} / 80$ & $-e, f /-e, f$ \\
\hline 32 & $\begin{array}{c}\operatorname{In}\left(\mathrm{OTf}_{3} / \mathrm{InCl}_{3} / \mathrm{DTBP}(40\right. \\
\text { equiv })\end{array}$ & $\mathrm{CH}_{3} \mathrm{CN}$ & $\mathrm{rt} / 80$ & $-e, f /-e, f$ \\
\hline 33 & $\mathrm{In}(\mathrm{OTf})_{3} / \mathrm{InCl}_{3} / \mathrm{ZnBr}_{2}$ & $\mathrm{CH}_{3} \mathrm{CN}$ & $\mathrm{rt} / 80$ & $-{ }^{d / 1.9 \%}$ \\
\hline 34 & $\mathrm{In}(\mathrm{OTf})_{3} / \mathrm{InCl}_{3} / \mathrm{Zn}(\mathrm{OAc})_{2}$ & $\mathrm{CH}_{3} \mathrm{CN}$ & $\mathrm{rt} / 80$ & $-d / 2.9 \%$ \\
\hline
\end{tabular}




\begin{tabular}{|c|c|c|c|c|}
\hline 35 & $\operatorname{In}(\mathrm{OTf})_{3} / \mathrm{InCl}_{3} / \mathrm{Yb}(\mathrm{OTf})_{3}$ & $\mathrm{CH}_{3} \mathrm{CN}$ & $\mathrm{rt} / 80$ & ${ }^{e, f} /$ Trace \\
\hline 36 & $\begin{array}{c}\mathrm{In}(\mathrm{OTf})_{3} / \mathrm{InCl}_{3} / \mathrm{LiClO}_{4}(3 \\
\text { equiv })\end{array}$ & $\mathrm{CH}_{3} \mathrm{CN}$ & $\mathrm{rt} / 80$ & Trace/Trace \\
\hline 37 & $\begin{array}{c}\operatorname{In}(\mathrm{OTf})_{3} / \mathrm{InCl}_{3} / p \text {-Chloranil } \\
\text { (3 equiv) }\end{array}$ & $\mathrm{CH}_{3} \mathrm{CN}$ & $\mathrm{rt} / 80$ & $-{ }_{-e, f} /-e, f$ \\
\hline 38 & $\begin{array}{c}\mathrm{In}(\mathrm{OTf})_{3} / \mathrm{InCl}_{3} / \mathrm{DDQ}(3 \\
\text { equiv) }\end{array}$ & $\mathrm{CH}_{3} \mathrm{CN}$ & $\mathrm{rt} / 80$ & $-{ }^{e, f} /\left.\right|_{-} e, f$ \\
\hline 39 & $\mathrm{In}(\mathrm{OAc})_{3} / \mathrm{InCl}_{3} / \mathrm{In}(\mathrm{OTf})_{3}$ & $\mathrm{CH}_{3} \mathrm{CN}$ & $\mathrm{rt} / 80$ & Trace/ $/{ }^{e, f}$ \\
\hline 40 & $\mathrm{InCl}_{3} / \mathrm{In}(\mathrm{OTf})_{3} / \mathrm{Bi}(\mathrm{OTf})_{3}$ & $\mathrm{CH}_{3} \mathrm{CN}$ & $\mathrm{rt} / 80$ & $-e, f /-e, f$ \\
\hline 41 & $\begin{array}{c}\text { TMSOTf } / \mathrm{InCl}_{3} / \mathrm{DTBP}(40 \\
\text { equiv)/In(OTf) })_{3}\end{array}$ & $\mathrm{CH}_{3} \mathrm{CN}$ & $\mathrm{rt} / 80$ & $-e . f /-e, f$ \\
\hline
\end{tabular}

${ }^{a} Z / E 19$ was $0.2 \mathrm{mM}$ unless noted. ${ }^{b}$ Lewis acid is 10.0 equiv unless noted. ${ }^{c}$ Yields were determined on the basis of UV-Vis absorption spectroscopy. ${ }^{d} \mathrm{~A}$ small amount of unknown bacteriochlorin was observed $(<10 \%)$. ${ }^{e}$ No absorption peak was detected at wavelengths $>600$ $\mathrm{nm}$. ${ }^{f}$ The starting material was consumed. ${ }^{g}$ No reaction occurred. ${ }^{h} Z / E 19$ was $0.1 \mathrm{mM} .{ }^{i} Z / E$ 19 was $3 \mathrm{mM}$. ${ }^{i} Z / E 19$ was $5 \mathrm{mM}$.

Table S4. Investigation of conditions for formation of chlorin 23 from compound 20. ${ }^{a}$

\begin{tabular}{|c|c|c|c|c|}
\hline Entry & Lewis acid $^{b}$ and Additive & Solvent & Temp $\left({ }^{\circ} \mathrm{C}\right)$ & Yield $^{c}$ \\
\hline 1 & $\mathrm{Sc}(\mathrm{OTf})_{3}$ & $\mathrm{CH}_{3} \mathrm{CN}$ & $\mathrm{rt} / 80$ & $-{ }^{e} /-^{d}$ \\
\hline 2 & $\mathrm{Sc}(\mathrm{OTf})_{3}$ & $\mathrm{CH}_{2} \mathrm{Cl}_{2}$ & $\mathrm{rt} / 40$ & $-{ }^{d} /{ }^{d}$ \\
\hline 3 & $\mathrm{Yb}(\mathrm{OTf})_{3}$ & $\mathrm{CH}_{3} \mathrm{CN}$ & $\mathrm{rt} / 80$ & $--^{e}-^{e}$ \\
\hline 4 & $\mathrm{Yb}(\mathrm{OTf})_{3}$ & $\mathrm{CH}_{2} \mathrm{Cl}_{2}$ & $\mathrm{rt} / 40$ & $-e /-^{d}$ \\
\hline 5 & $\operatorname{In}(\mathrm{OTf})_{3}$ & $\mathrm{CH}_{3} \mathrm{CN}$ & $\mathrm{rt} / 80$ & $-e / 3.9$ \\
\hline 6 & $\operatorname{In}(\mathrm{OTf})_{3}$ & $\mathrm{CH}_{2} \mathrm{Cl}_{2}$ & $\mathrm{rt} / 40$ & $-{ }^{d /} /{ }^{d}$ \\
\hline 7 & $\mathrm{Sc}(\mathrm{OTf})_{3} / \mathrm{DTBP}$ & $\mathrm{CH}_{3} \mathrm{CN}$ & $\mathrm{rt} / 80$ & $-g / e^{e}$ \\
\hline 8 & $\mathrm{Sc}(\mathrm{OTf})_{3} / \mathrm{DTBP}$ & $\mathrm{CH}_{2} \mathrm{Cl}_{2}$ & $\mathrm{rt} / 40$ & $-g / \perp^{e}$ \\
\hline 9 & $\mathrm{Yb}(\mathrm{OTf})_{3} / \mathrm{DTBP}$ & $\mathrm{CH}_{3} \mathrm{CN}$ & $\mathrm{rt} / 80$ & $-g /-^{e}$ \\
\hline 10 & $\mathrm{Yb}(\mathrm{OTf})_{3} / \mathrm{DTBP}$ & $\mathrm{CH}_{2} \mathrm{Cl}_{2}$ & $\mathrm{rt} / 40$ & $-g /-e$ \\
\hline 11 & $\operatorname{In}(\mathrm{OTf})_{3} / \mathrm{DTBP}$ & $\mathrm{CH}_{3} \mathrm{CN}$ & $\mathrm{rt} / 80$ & $-g / e^{e}$ \\
\hline 12 & $\operatorname{In}(\mathrm{OTf})_{3} / \mathrm{DTBP}$ & $\mathrm{CH}_{2} \mathrm{Cl}_{2}$ & $\mathrm{rt} / 40$ & $g / \_g$ \\
\hline 13 & TMSOTf/DTBP & $\mathrm{CH}_{3} \mathrm{CN}$ & $\mathrm{rt} / 80$ & $-g / g$ \\
\hline 14 & TMSOTf/DTBP & $\mathrm{CH}_{2} \mathrm{Cl}_{2}$ & $\mathrm{rt} / 40$ & $\unlhd^{g} /{ }^{d}$ \\
\hline 15 & $\mathrm{In}(\mathrm{OTf})_{3} / \mathrm{InCl}_{3}$ & $\mathrm{CH}_{3} \mathrm{CN}$ & 80 & 16 \\
\hline 16 & TMSOTf/DTBP/Yb(OTf $)_{3}$ & $\mathrm{CH}_{3} \mathrm{CN}$ & $\mathrm{rt} / 80$ & $-g / \_^{e}$ \\
\hline 17 & TMSOTf/DTBP/Sc(OTf $)_{3}$ & $\mathrm{CH}_{3} \mathrm{CN}$ & $\mathrm{rt} / 80$ & $-^{d} / 2.7$ \\
\hline 18 & TMSOTf/DTBP/In(OTf $)_{3}$ & $\mathrm{CH}_{3} \mathrm{CN}$ & $\mathrm{rt} / 80$ & $-^{d} / 4.6$ \\
\hline 19 & TMSOTf/DTBP/Yb(OTf) $)_{3} / \mathrm{ZnBr}_{2}$ & $\mathrm{CH}_{3} \mathrm{CN}$ & 80 & $-^{e}$ \\
\hline
\end{tabular}




$\begin{array}{lclll}20 & \text { TMSOTf/DTBP/Sc(OTf })_{3} / \mathrm{ZnBr}_{2} & \mathrm{CH}_{3} \mathrm{CN} & 80 & -{ }^{e} \\ 21 & \text { TMSOTf/DTBP/In }(\mathrm{OTf})_{3} / \mathrm{ZnBr}_{2} & \mathrm{CH}_{3} \mathrm{CN} & 80 & -{ }^{e} \\ 22 & \mathrm{TMSOTf} / \mathrm{DTBP} / \mathrm{In}(\mathrm{OTf})_{3} / \mathrm{InCl}_{3} & \mathrm{CH}_{3} \mathrm{CN} & 80 & 13 \\ 23 & \mathrm{TMSOTf} / \mathrm{DTBP} / \mathrm{In}(\mathrm{OTf})_{3} / \mathrm{InCl}_{3} / \mathrm{Zn}(\mathrm{OAc})_{2} & \mathrm{CH}_{3} \mathrm{CN} & 80 & -^{e}\end{array}$

${ }^{a} \mathrm{Z} / \mathrm{E} 20$ was $0.2 \mathrm{mM} .{ }^{b}$ Lewis acid is 10.0 equiv and DTBP is 40.0 equiv. ${ }^{c}$ Yields were determined on the basis of UV-Vis absorption spectroscopy. ${ }^{d} \mathrm{~A}$ small amount of unknown bacteriochlorin was observed $(<10 \%)$. ${ }^{e}$ No absorption peak was detected at wavelengths $>600$ nm. ${ }^{g}$ No reaction occurred.

Table S5. Investigation of conditions for chlorin formation from compound (Boc) $)_{2}-19{ }^{a}$

\begin{tabular}{|c|c|c|c|c|}
\hline Entry & Lewis acid ${ }^{b}$ & Solvent & Temperature $\left({ }^{\circ} \mathrm{C}\right)$ & Yield $^{c}$ \\
\hline 1 & $\mathrm{BF}_{3} \cdot \mathrm{OEt}_{2}$ & $\mathrm{CH}_{2} \mathrm{Cl}_{2}$ & $\mathrm{rt} / 40$ & $-e^{e, f} /-e, f$ \\
\hline 2 & $\operatorname{Mg}(\mathrm{OTf})_{2}$ & $\mathrm{CH}_{3} \mathrm{CN}$ & $\mathrm{rt} / 80$ & $-{ }_{-}^{e, g} /{ }_{-} e, f$ \\
\hline 3 & $\mathrm{Sc}(\mathrm{OTf})_{3}$ & $\mathrm{CH}_{2} \mathrm{Cl}_{2}$ & $\mathrm{rt} / 40$ & $-e, f /-e, f$ \\
\hline 4 & $\mathrm{FeCl}_{3}$ & $\mathrm{CH}_{3} \mathrm{CN}$ & $\mathrm{rt} / 80$ & $-e, f /-e, f$ \\
\hline 5 & $\mathrm{PdBr}_{2}$ & $\mathrm{CH}_{3} \mathrm{CN}$ & $\mathrm{rt} / 80$ & $-{ }_{-e, g /-e, f}$ \\
\hline 6 & $\mathrm{InCl}_{3}$ & $\mathrm{CH}_{2} \mathrm{Cl}_{2}$ & $\mathrm{rt} / 40$ & $-{ }^{d} /{ }^{d}$ \\
\hline 7 & $\operatorname{In}(\mathrm{OTf})_{3}$ & $\mathrm{CH}_{2} \mathrm{Cl}_{2}$ & $\mathrm{rt} / 40$ & $-e, f f_{-}^{d}$ \\
\hline 8 & $\operatorname{Gd}(\mathrm{OTf})_{3}$ & $\mathrm{CH}_{3} \mathrm{CN}$ & $\mathrm{rt} / 80$ & $-e, f /-e, f$ \\
\hline 9 & $\operatorname{Er}(\mathrm{OTf})_{3}$ & $\mathrm{CH}_{3} \mathrm{CN}$ & $\mathrm{rt} / 80$ & $-\iota^{e, g} / \__{e, f}$ \\
\hline 10 & $\mathrm{Yb}(\mathrm{OTf})_{3}$ & $\mathrm{CH}_{2} \mathrm{Cl}_{2}$ & $\mathrm{rt} / 40$ & $-e, f /{ }^{d}$ \\
\hline 11 & $\mathrm{Hf}(\mathrm{OTf})_{4}$ & $\mathrm{CH}_{2} \mathrm{Cl}_{2}$ & $\mathrm{rt} / 40$ & $-e^{e, f} /-e, f$ \\
\hline 12 & $\mathrm{IrCl}_{3}$ & $\mathrm{CH}_{3} \mathrm{CN}$ & $\mathrm{rt} / 80$ & $-{ }^{d} /-^{d}$ \\
\hline 13 & $\mathrm{AuCl}_{3}$ & $\mathrm{CH}_{3} \mathrm{CN}$ & $\mathrm{rt} / 80$ & $-e, f /-e, f$ \\
\hline 14 & $\mathrm{Bi}(\mathrm{OTf})_{3}$ & $\mathrm{CH}_{3} \mathrm{CN}$ & $\mathrm{rt} / 80$ & $-d /-e, f$ \\
\hline 15 & TMSOTf & $\mathrm{CH}_{2} \mathrm{Cl}_{2}$ & $\mathrm{rt} / 40$ & $-e, f /-e, f$ \\
\hline 16 & $\operatorname{In}(\mathrm{OTf})_{3} / \mathrm{InCl}_{3}$ & $\mathrm{CH}_{3} \mathrm{CN}$ & $\mathrm{rt} / 80$ & $-d /-e, g$ \\
\hline 17 & $\mathrm{Yb}(\mathrm{OTf})_{3} / \operatorname{In}(\mathrm{OTf})_{3}$ & $\mathrm{CH}_{3} \mathrm{CN}$ & $\mathrm{rt} / 80$ & $-e, f /-e, f$ \\
\hline 18 & $\mathrm{Yb}(\mathrm{OTf})_{3} / \mathrm{InCl}_{3}$ & $\mathrm{CH}_{3} \mathrm{CN}$ & $\mathrm{rt} / 80$ & $-e, g /-e, f$ \\
\hline 19 & $\mathrm{Bi}(\mathrm{OTf})_{3} / \mathrm{InCl}_{3}$ & $\mathrm{CH}_{3} \mathrm{CN}$ & $\mathrm{rt} / 80$ & $-d /-e f f$ \\
\hline
\end{tabular}

${ }^{a}$ (Boc) $)_{2}-19$ was 0.2 mM. ${ }^{b}$ Lewis acid is 10.0 equiv unless noted. ${ }^{c}$ Yields were determined on the basis of UV-Vis absorption spectroscopy. ${ }^{d} \mathrm{~A}$ small amount of unknown bacteriochlorin was observed $(<10 \%)$. ${ }^{e}$ No absorption peak was detected $>600 \mathrm{~nm}$. ${ }^{f}$ The starting material was consumed. ${ }^{g}$ No reaction occurred. 
Table S6. Investigation of conditions for $N$-BOC deprotection of (Boc) $)_{2}-19$ and (Boc) $)_{2}-20$.

\begin{tabular}{|c|c|c|c|c|c|}
\hline Entry & $(\mathrm{Boc})_{2}-\mathrm{XX}(\mathrm{mM})$ & Condition & Solvent & Temp, ${ }^{\circ} \mathrm{C}$ & Results \\
\hline 1 & 19, $20 \mathrm{mM}$ & $\begin{array}{c}\mathrm{TFA} / \mathrm{CH}_{2} \mathrm{Cl}_{2}(1: 4), \text { argon, } \\
\text { overnight }\end{array}$ & $\mathrm{CH}_{2} \mathrm{Cl}_{2}$ & $\mathrm{rt}$ & $-a, b, c$ \\
\hline 2 & 20, $10 \mathrm{mM}$ & $\begin{array}{c}\mathrm{TFA} / \mathrm{CH}_{2} \mathrm{Cl}_{2}(1: 4), \text { air, } \\
\text { overnight }\end{array}$ & $\mathrm{CH}_{2} \mathrm{Cl}_{2}$ & $\mathrm{rt}$ & $-a, b, c$ \\
\hline 3 & $19,0.2 \mathrm{mM}$ & $\mathrm{TFA} / \mathrm{CH}_{2} \mathrm{Cl}_{2}(1: 2)$, air, $3 \mathrm{~h}$ & $\mathrm{CH}_{2} \mathrm{Cl}_{2}$ & $\mathrm{rt}$ & $\_a, b, c$ \\
\hline 4 & $\mathbf{1 9}, 10 \mathrm{mM}$ & TMSI, air, $16 \mathrm{~h}$ & $\mathrm{CH}_{3} \mathrm{CN}$ & $\mathrm{rt}$ & $-^{a, c}$ \\
\hline 5 & $\mathbf{2 0}, 10 \mathrm{mM}$ & TMSI, air, $16 \mathrm{~h}$ & $\mathrm{CH}_{3} \mathrm{CN}$ & $\mathrm{rt}$ & $\_^{a, c}$ \\
\hline 6 & $19,0.2 \mathrm{mM}$ & TMSI, air, $16 \mathrm{~h}$ & $\mathrm{CH}_{2} \mathrm{Cl}_{2}$ & $\mathrm{rt}$ & $\_^{a, c}$ \\
\hline 7 & $\mathbf{2 0}, 0.2 \mathrm{mM}$ & TMSI, air, $24 \mathrm{~h}$ & $\mathrm{CH}_{2} \mathrm{Cl}_{2}$ & $\mathrm{rt}$ & $\_^{a, c}$ \\
\hline 8 & 19, $0.4 \mathrm{mM}$ & TMSI, air, $18 \mathrm{~h}$ & $\mathrm{MeOH}$ & $\mathrm{rt}$ & $-^{a, c}$ \\
\hline 9 & $\mathbf{2 0}, 0.4 \mathrm{mM}$ & TMSI, air, $16 \mathrm{~h}$ & $\mathrm{MeOH}$ & $\mathrm{rt}$ & $-a, c$ \\
\hline
\end{tabular}

${ }^{a}$ The reaction process was monitored by TLC and the starting material was completely consumed. ${ }^{b} \mathrm{~A}$ trace amount of bacteriochlorin was detected by UV-Vis absorption spectroscopy but a yield was not determined. ${ }^{c 1} \mathrm{H}$ NMR spectroscopy showed no desired product formation.

\section{Absorption and fluorescence spectra}

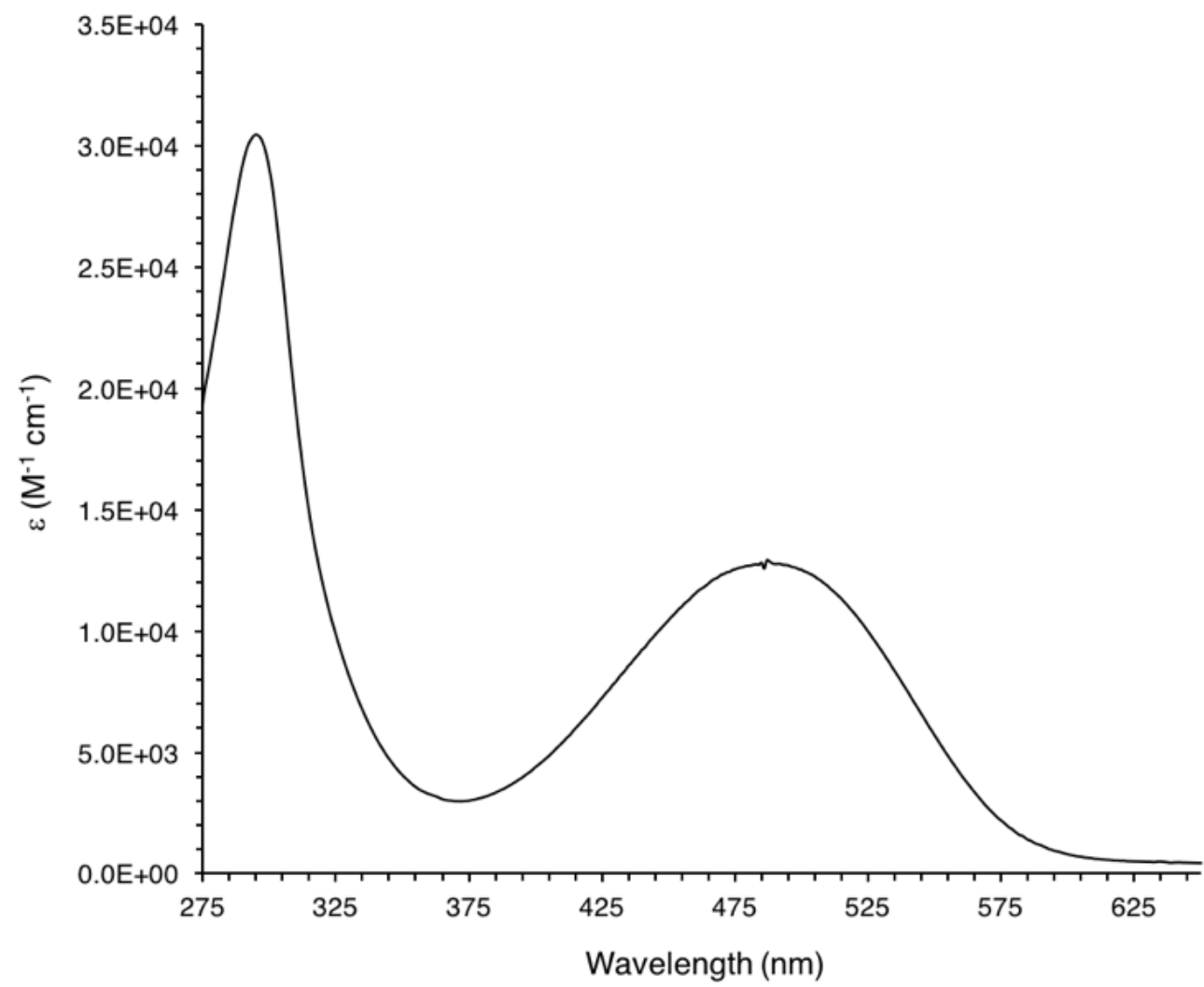

Figure S1. Absorption spectrum of 20 in $\mathrm{CH}_{3} \mathrm{CN}$ at room temperature. 


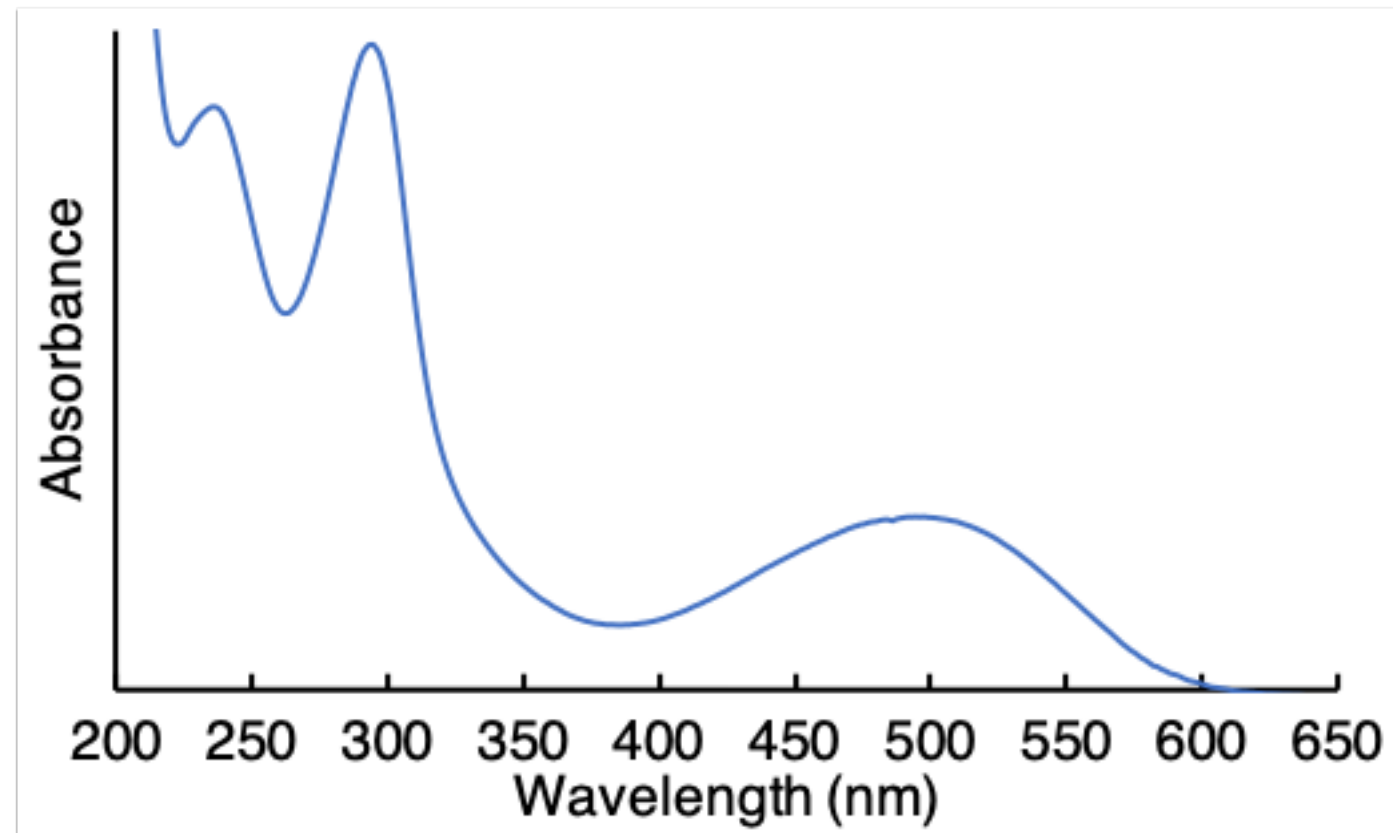

Figure S2. Absorption spectrum of a mixture of $Z / E$ isomers of 19 in $\mathrm{CH}_{3} \mathrm{CN}$ at room temperature. The peak absorption in the visible region is at $\sim 484 \mathrm{~nm}$.

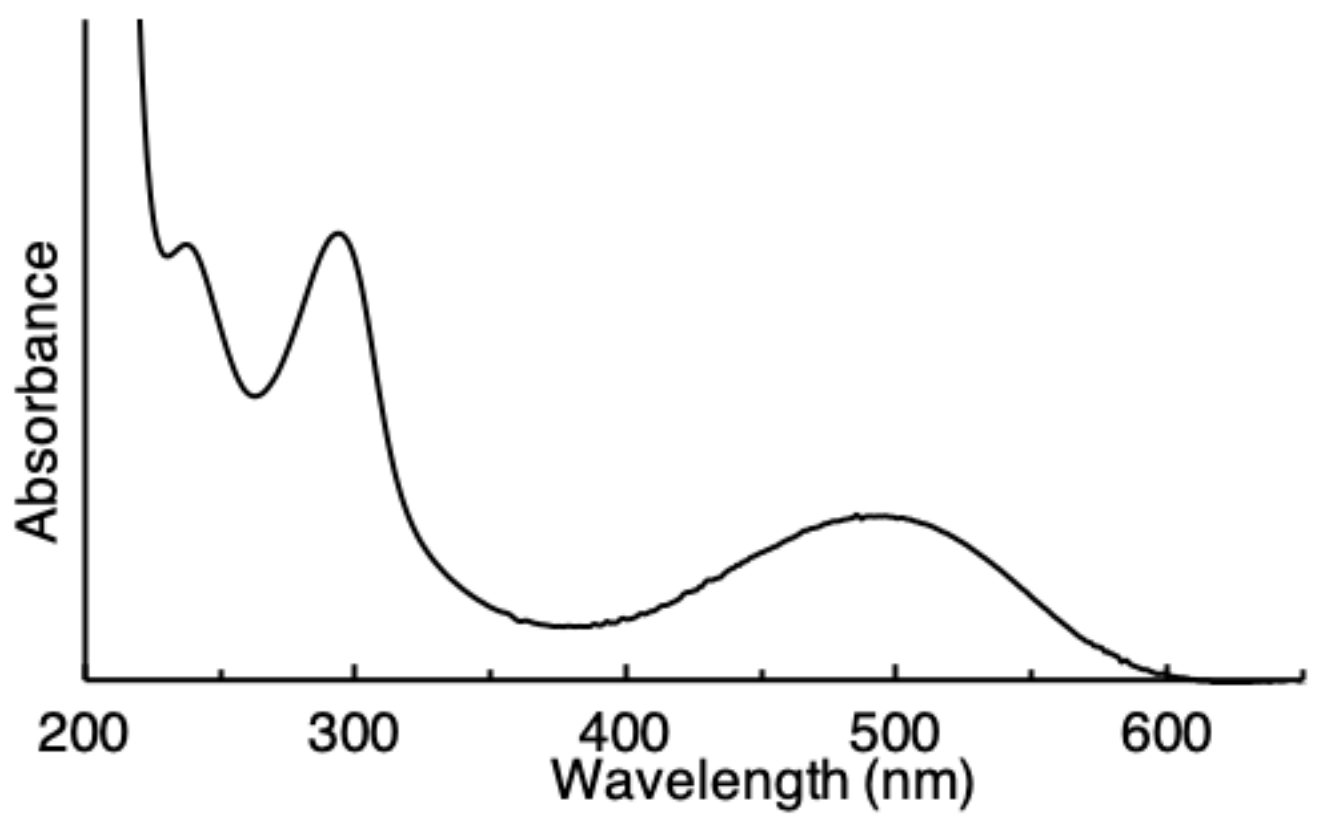

Figure S3. Absorption spectrum of the major isomer of 19 in $\mathrm{CH}_{3} \mathrm{CN}$ at room temperature. The peak absorption in the visible region is at $\sim 485 \mathrm{~nm}$. 


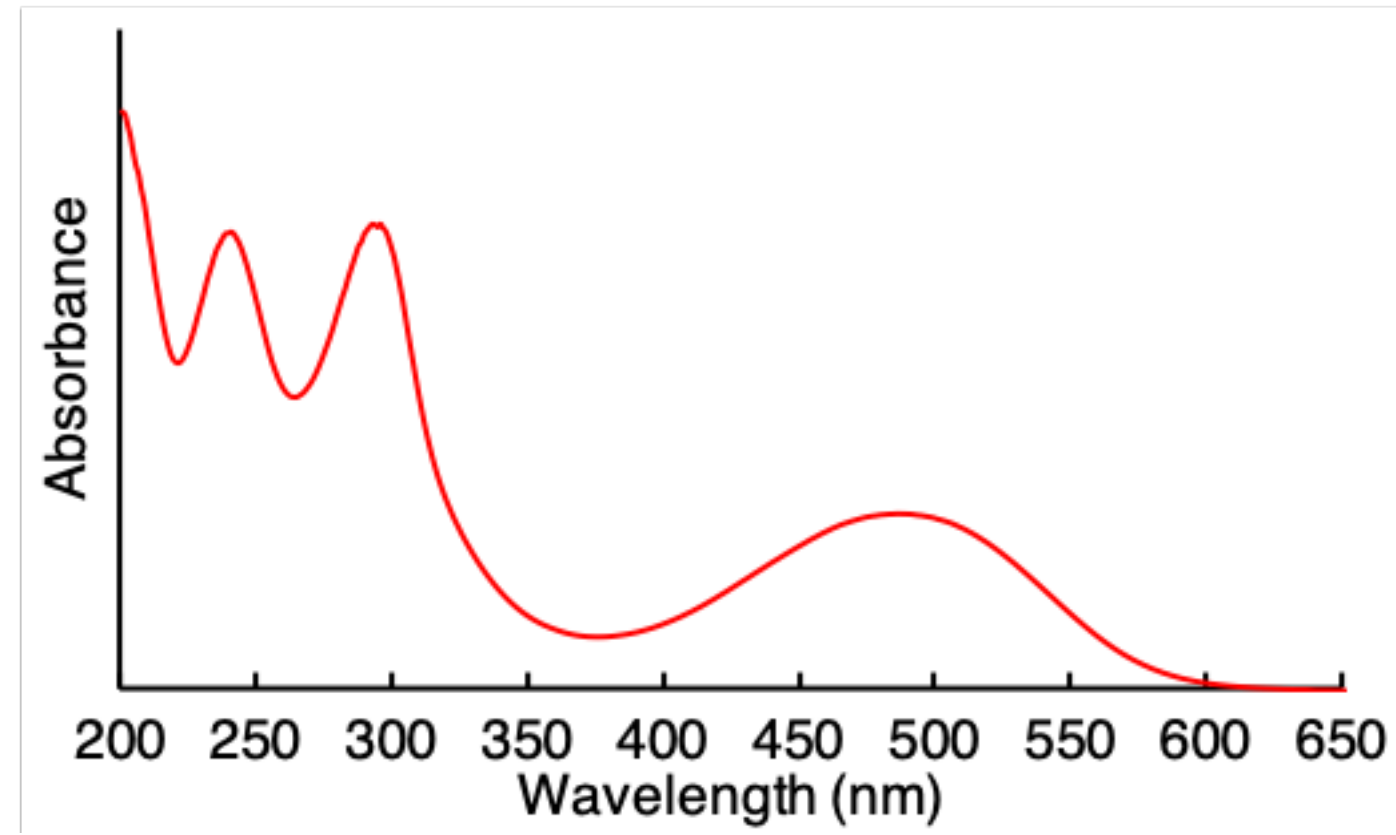

Figure S4. Absorption spectrum of a mixture of $Z / E$ isomers of 20 in $\mathrm{CH}_{3} \mathrm{CN}$ at room temperature. The peak absorption in the visible region is at $\sim 486 \mathrm{~nm}$.

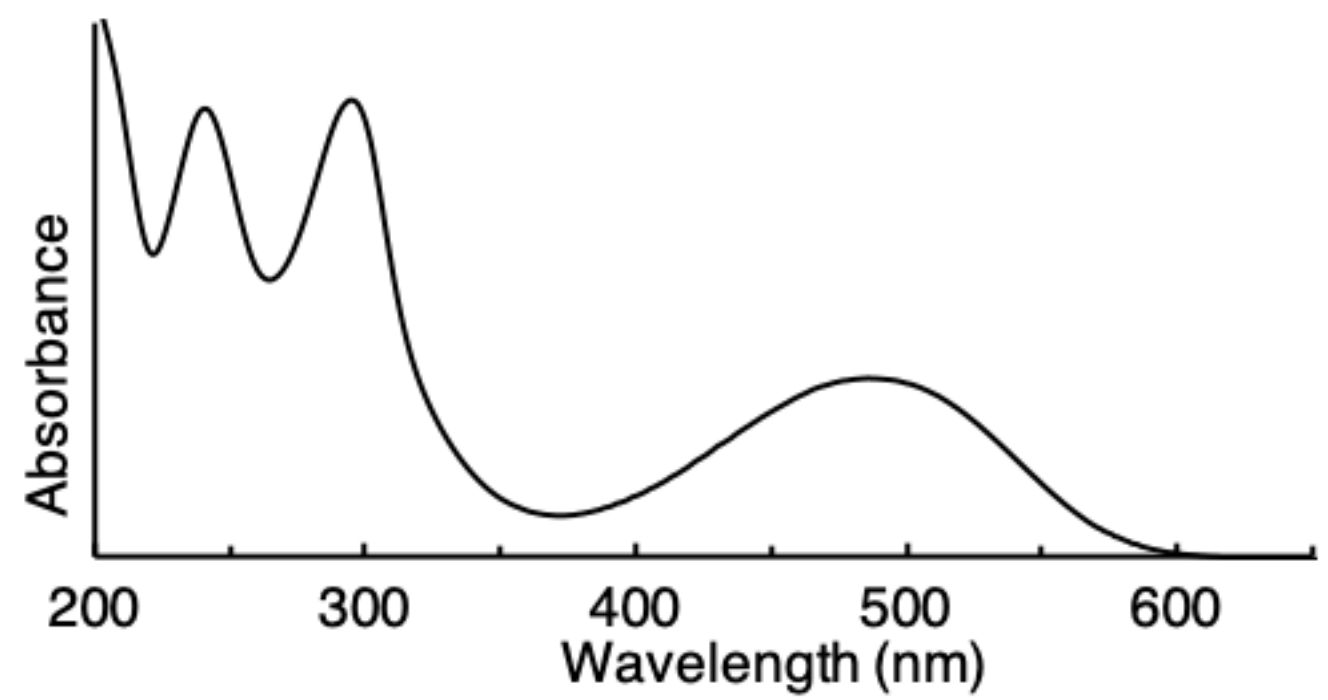

Figure S5. Absorption spectrum of $\boldsymbol{Z - 2 0}$ in $\mathrm{CH}_{3} \mathrm{CN}$ at room temperature. The peak absorption in the visible region is at $\sim 486 \mathrm{~nm}$. 


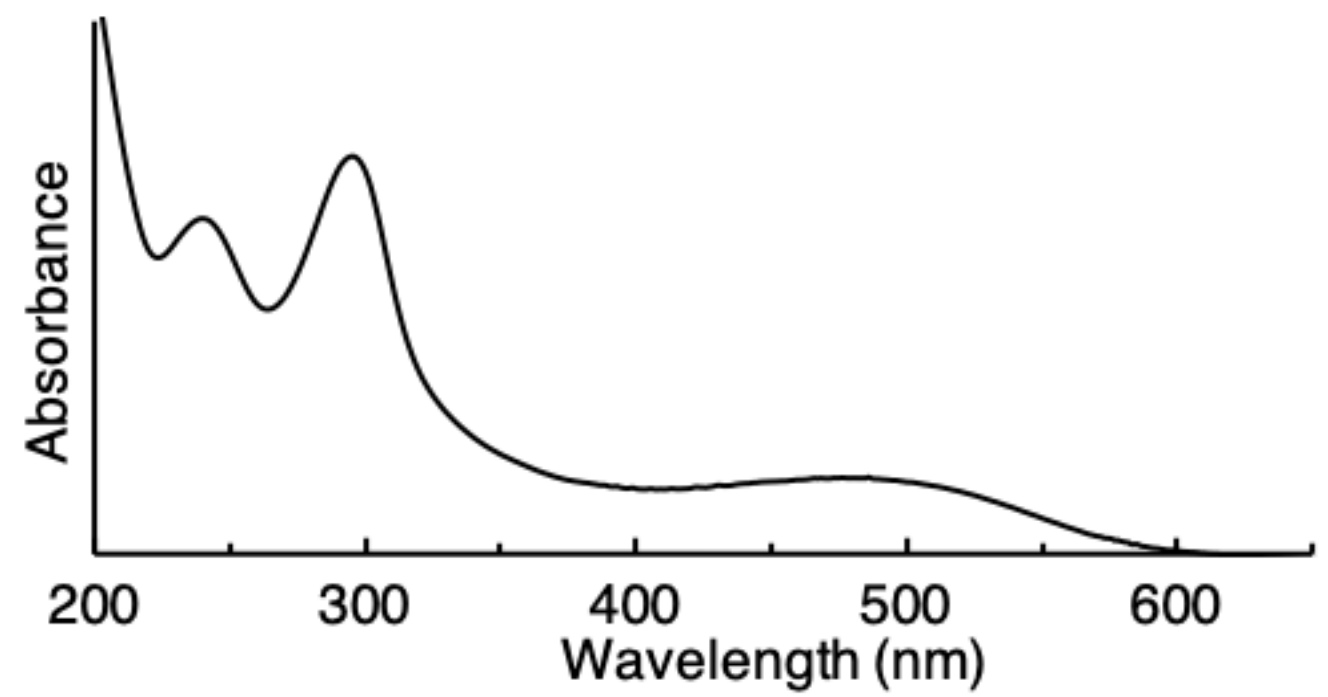

Figure S6. Absorption spectrum of $\boldsymbol{E - 2 0}$ in $\mathrm{CH}_{3} \mathrm{CN}$ at room temperature. The peak absorption in the visible region is at $\sim 486 \mathrm{~nm}$.

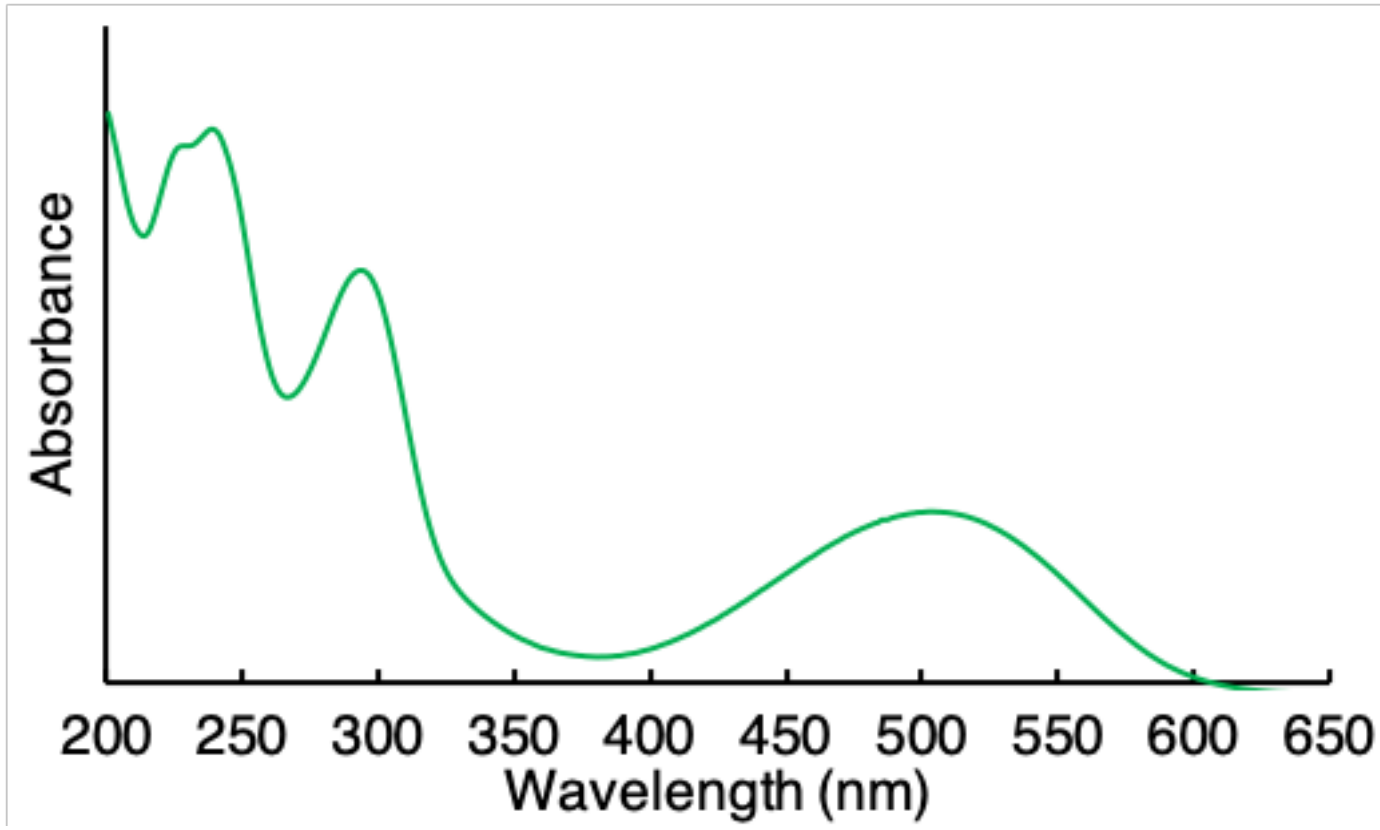

Figure S7. Absorption spectrum of (Boc) $)_{2}-19$ in $\mathrm{CH}_{3} \mathrm{CN}$ at room temperature. The peak absorption in the visible region is at $\sim 503 \mathrm{~nm}$. 


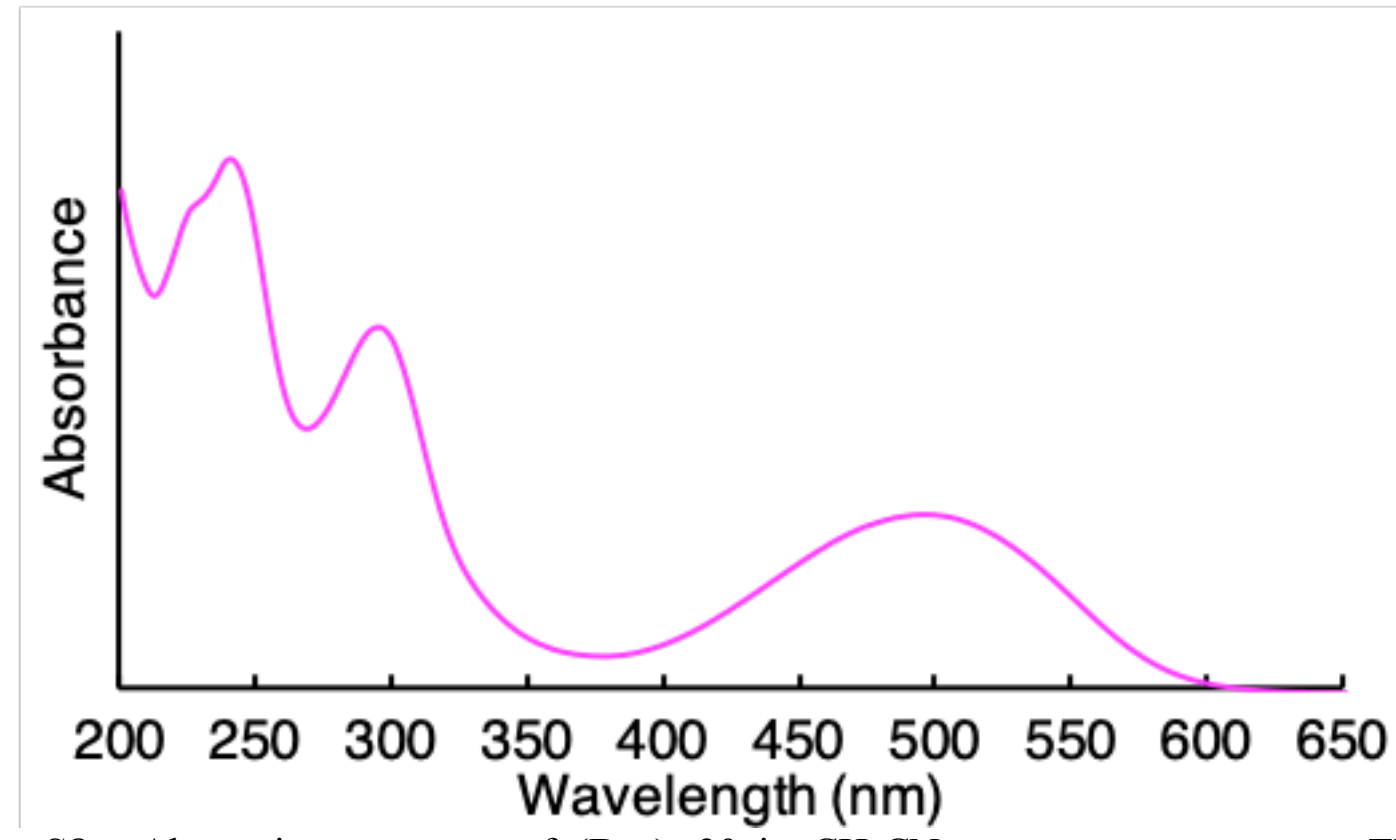

Figure S8. Absorption spectrum of (Boc) $)_{2}-20$ in $\mathrm{CH}_{3} \mathrm{CN}$ at room temperature. The peak absorption in the visible region is at $\sim 497 \mathrm{~nm}$.

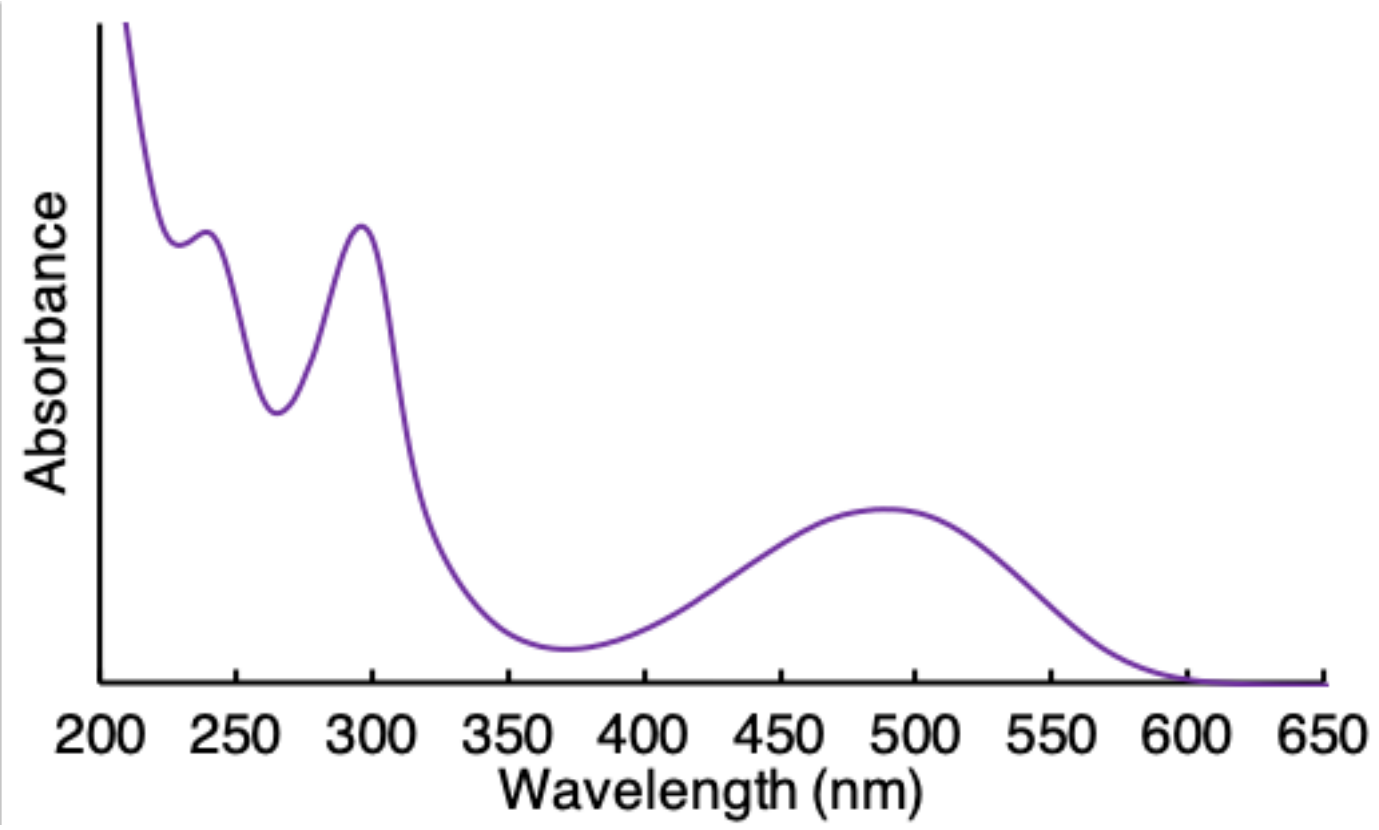

Figure S9. Absorption spectrum of a mixture of $Z / E$ isomers of 21 in $\mathrm{CH}_{3} \mathrm{CN}$ at room temperature. The peak absorption in the visible region is at $\sim 488 \mathrm{~nm}$. 


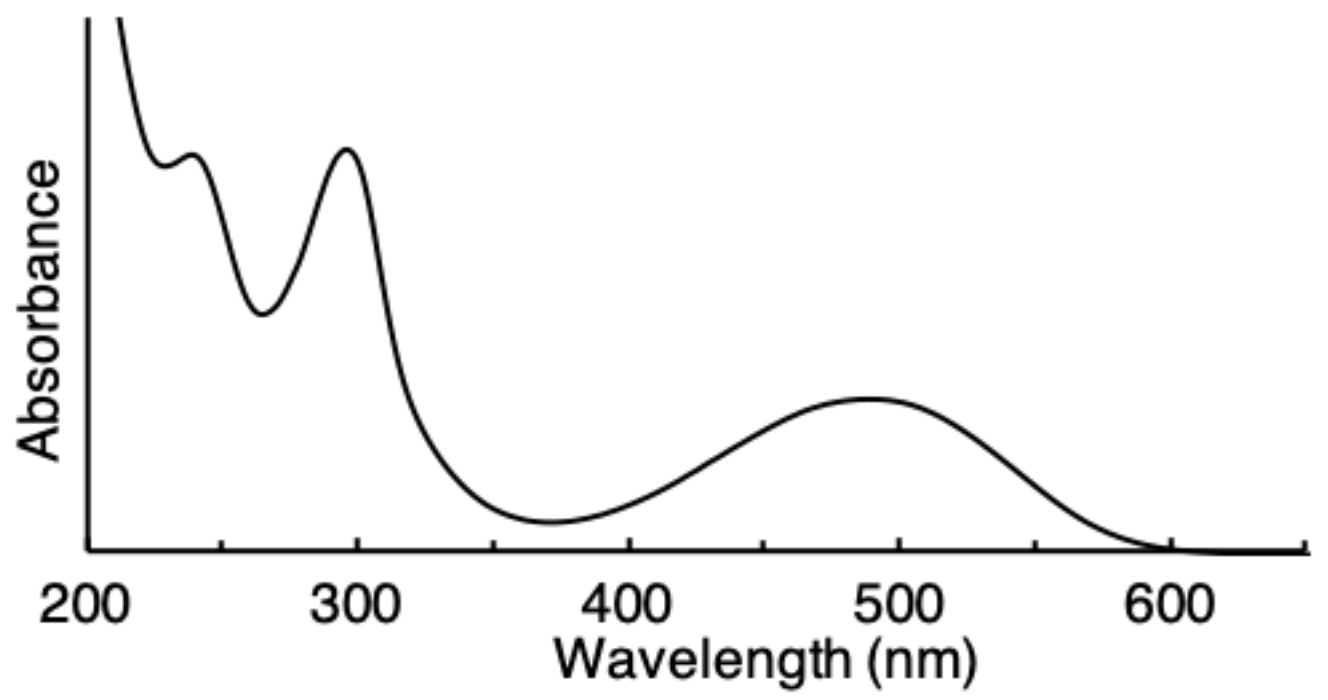

Figure S10. Absorption spectrum of the major isomer of 21 in $\mathrm{CH}_{3} \mathrm{CN}$ at room temperature. The peak absorption in the visible region is at $\sim 488 \mathrm{~nm}$.

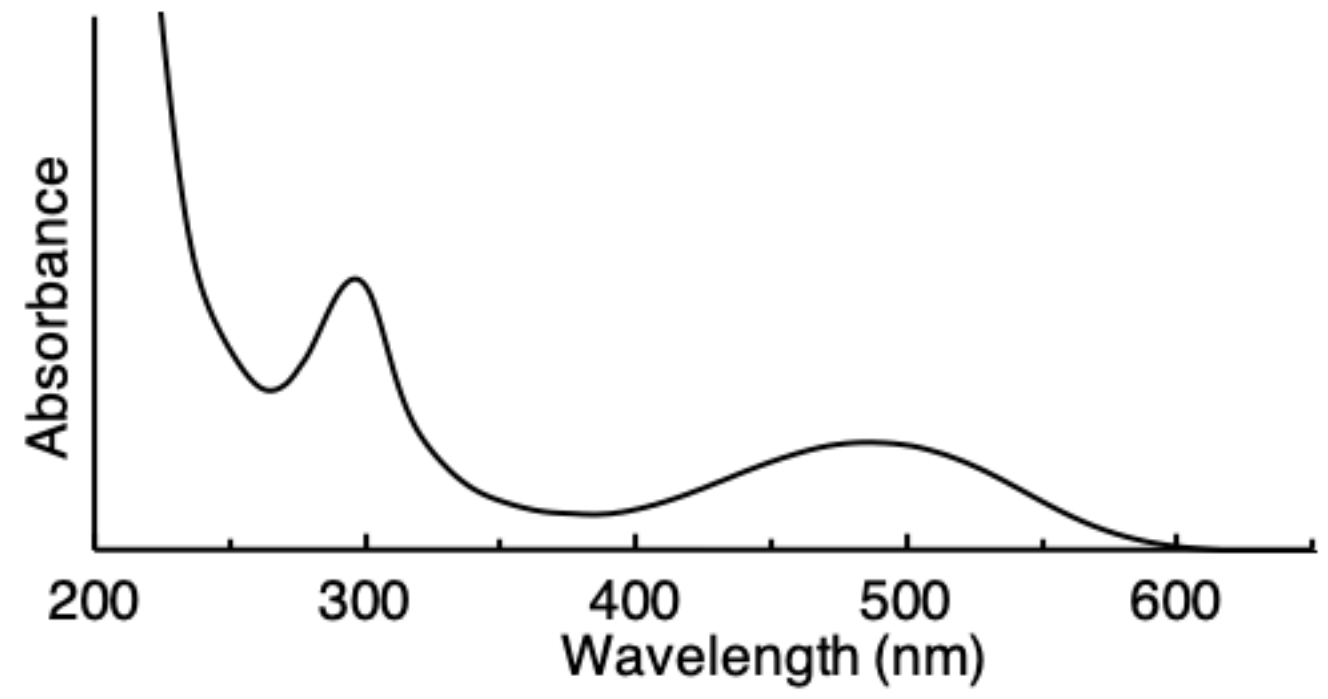

Figure S11. Absorption spectrum of the minor isomer of 21 in $\mathrm{CH}_{3} \mathrm{CN}$ at room temperature. The peak absorption in the visible region is at $\sim 487 \mathrm{~nm}$. 


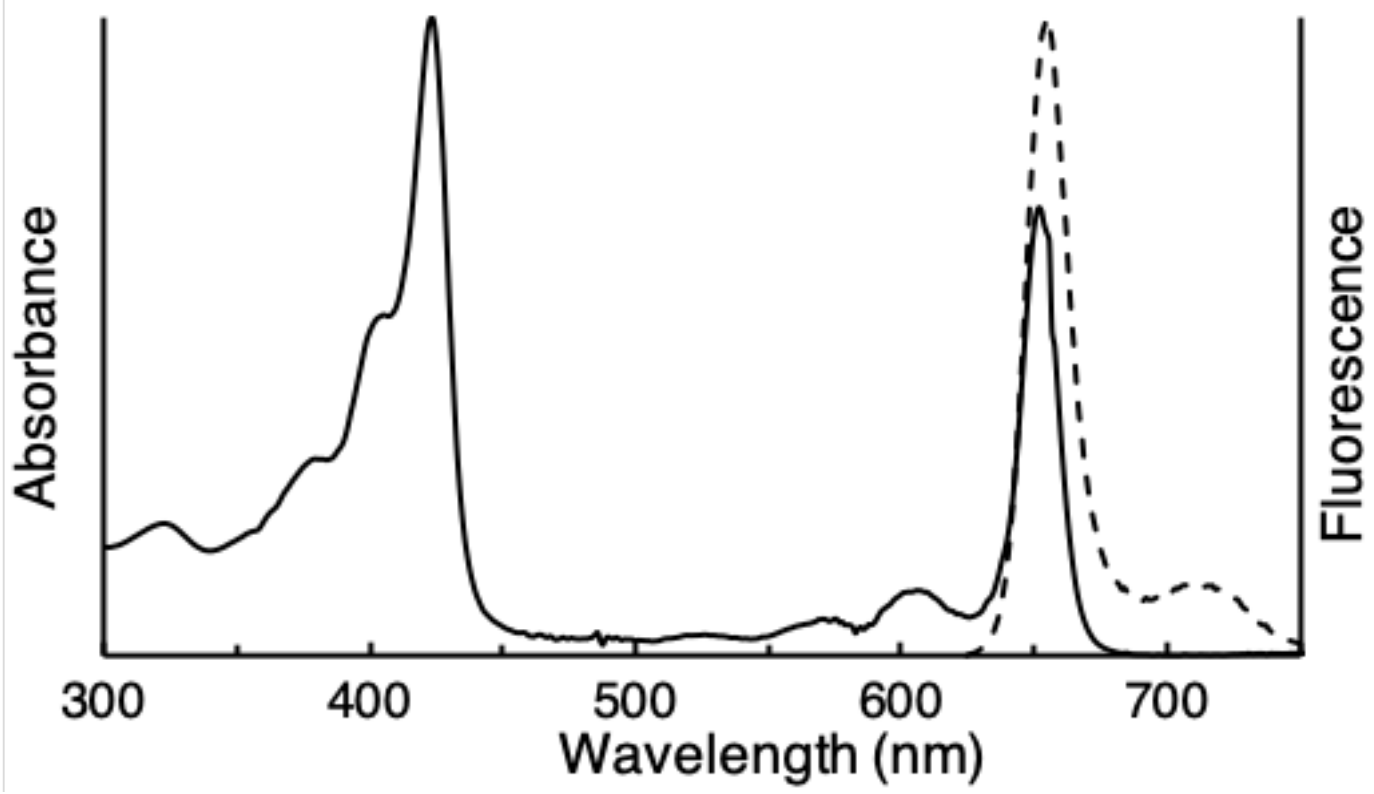

Figure S12. Absorption spectrum (solid line) and fluorescence spectrum (dashed line) of 23 in $\mathrm{CH}_{3} \mathrm{CN}$ at room temperature. The peak absorption in the red region is at $\sim 652 \mathrm{~nm}$ and fluorescence is at $655 \mathrm{~nm}$ (Stokes shift $=3 \mathrm{~nm}$ ).

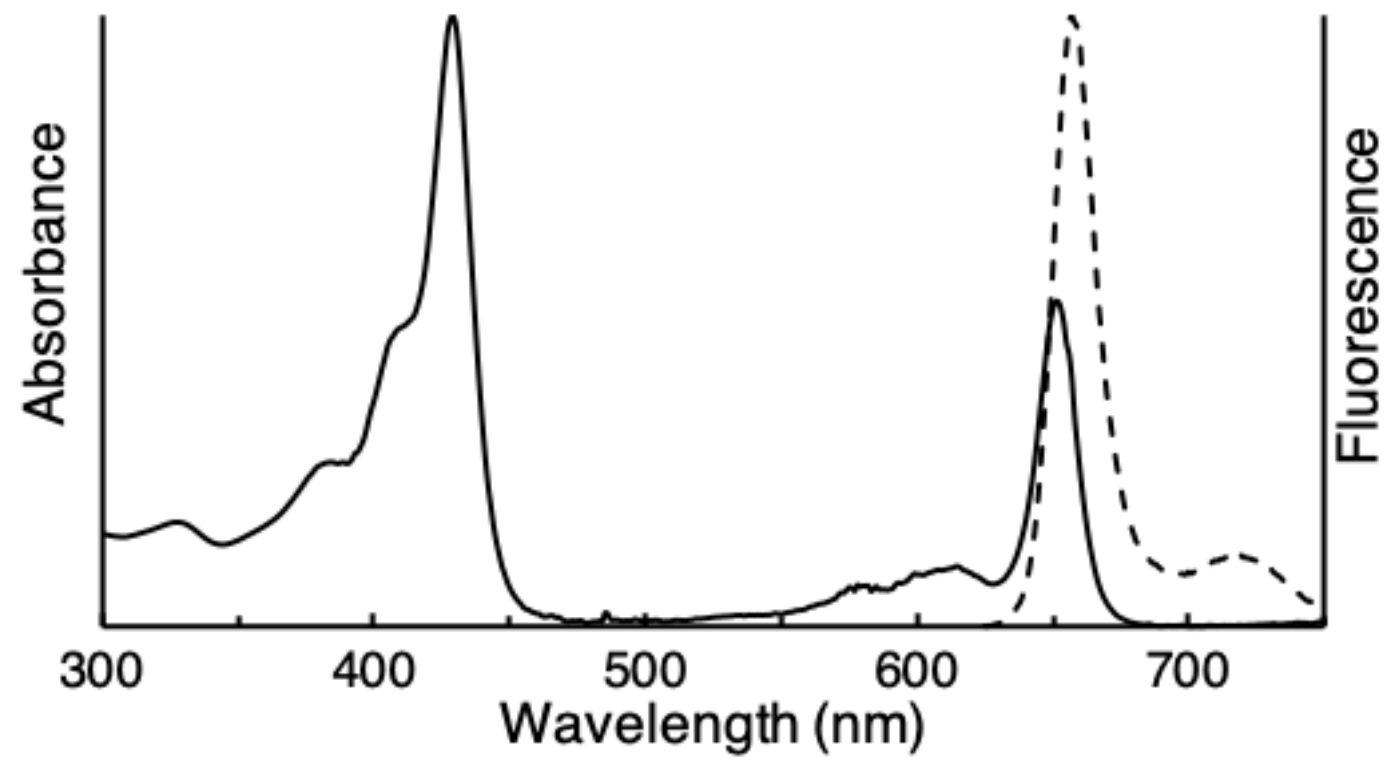

Figure S13. Absorption spectrum (solid line) and fluorescence spectrum (dashed line) of 24 in $\mathrm{CH}_{3} \mathrm{CN}$ at room temperature. The peak absorption in the red region is at $\sim 651 \mathrm{~nm}$ and fluorescence is at $657 \mathrm{~nm}$ (Stokes shift $=6 \mathrm{~nm})$. 


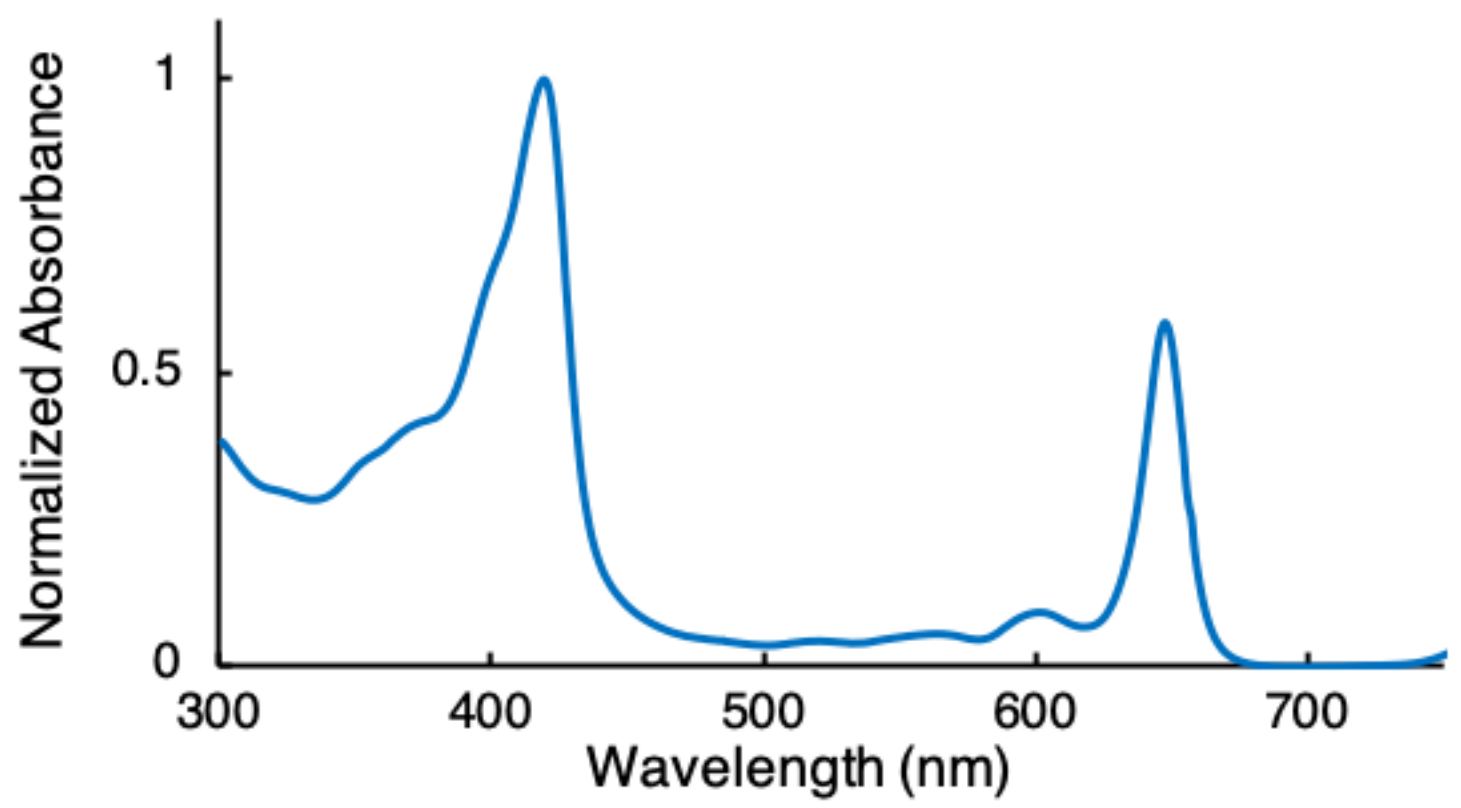

Figure S14. Absorption spectrum of 22 in $\mathrm{CH}_{3} \mathrm{CN}$ at room temperature. The peak absorption in the red region is at $\sim 647 \mathrm{~nm}$.

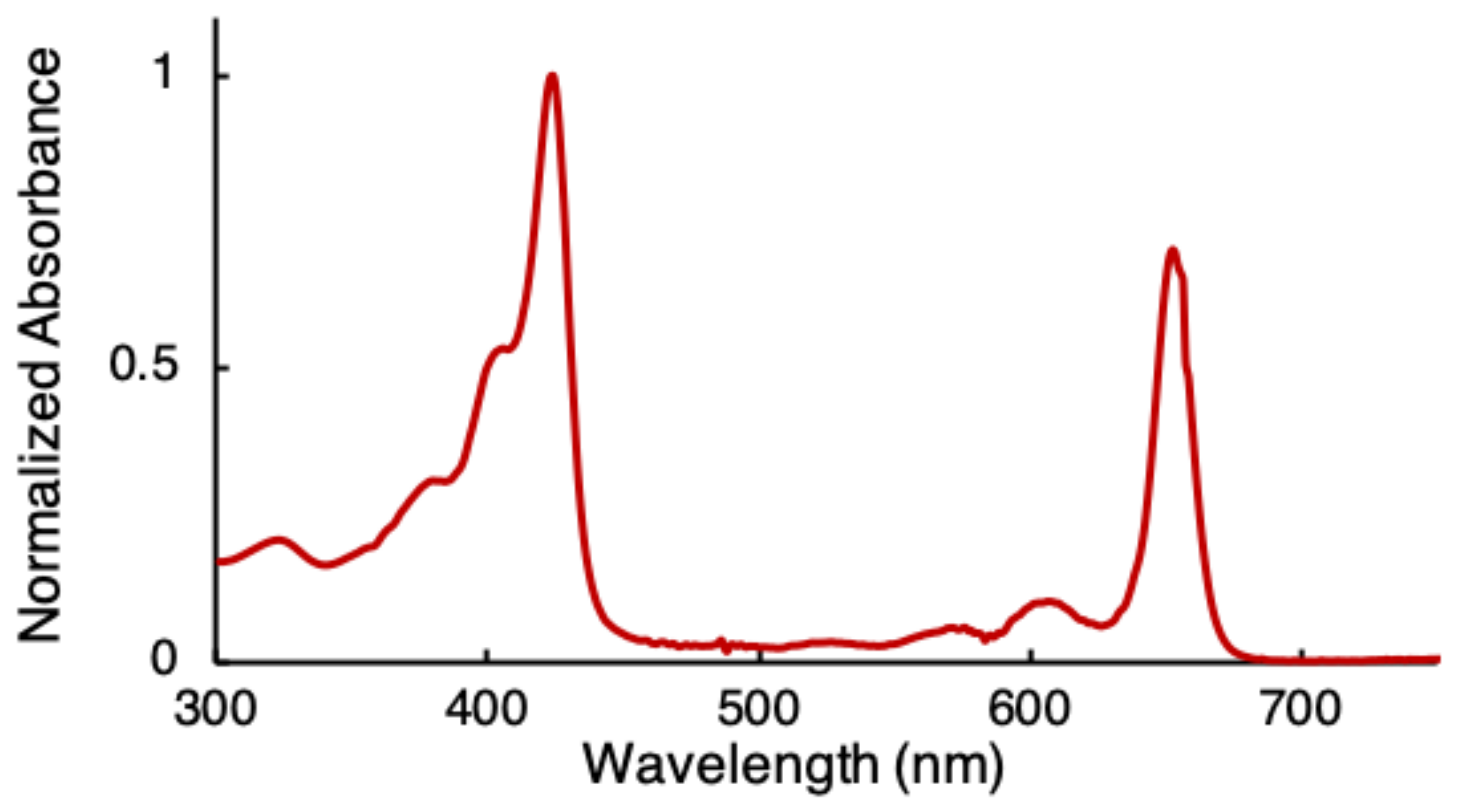

Figure S15. Absorption spectrum of 23 in $\mathrm{CH}_{3} \mathrm{CN}$ at room temperature. The peak absorption in the red region is at $\sim 652 \mathrm{~nm}$. 


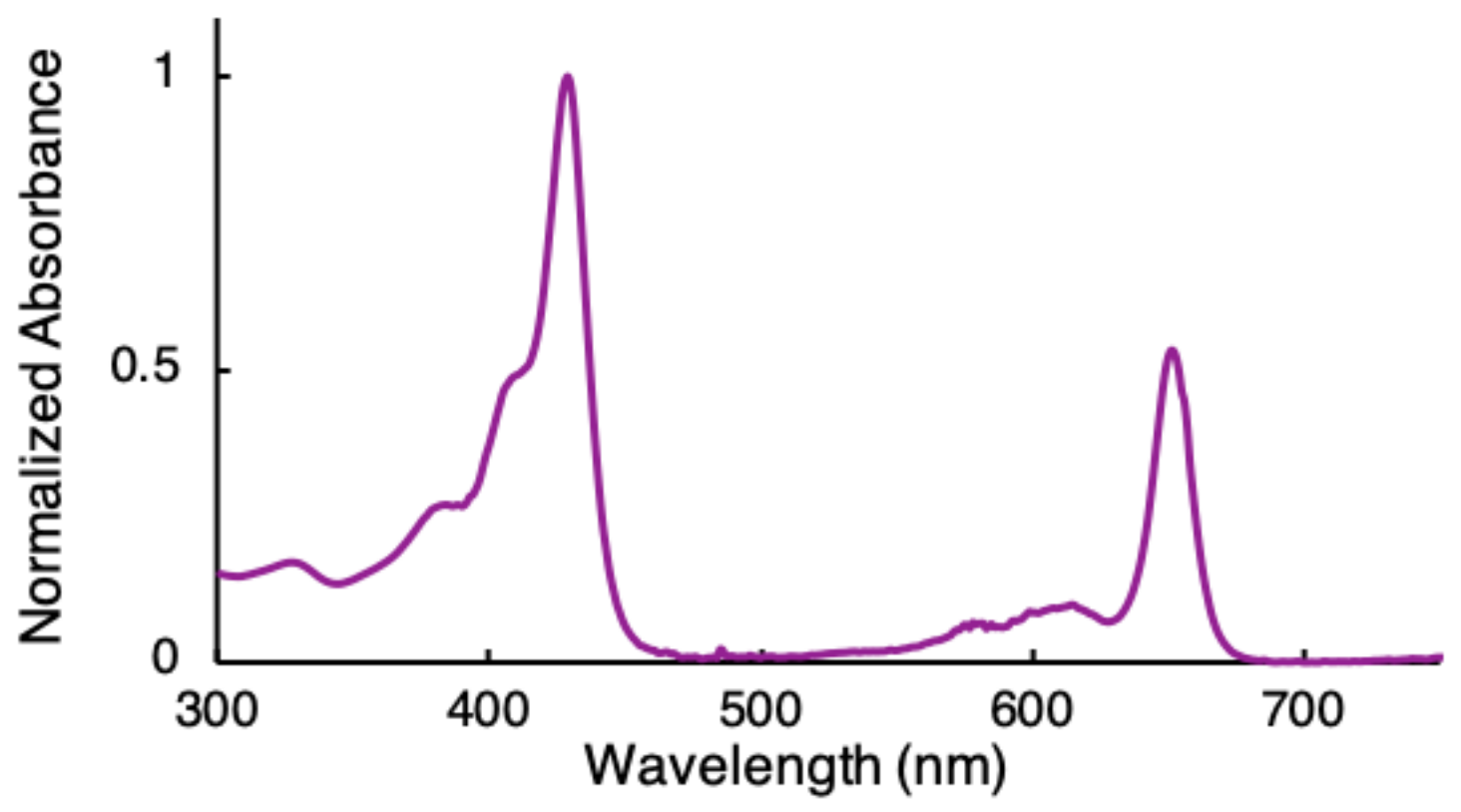

Figure S16. Absorption spectrum of 24 in $\mathrm{CH}_{3} \mathrm{CN}$ at room temperature. The peak absorption in the red region is at $\sim 651 \mathrm{~nm}$.

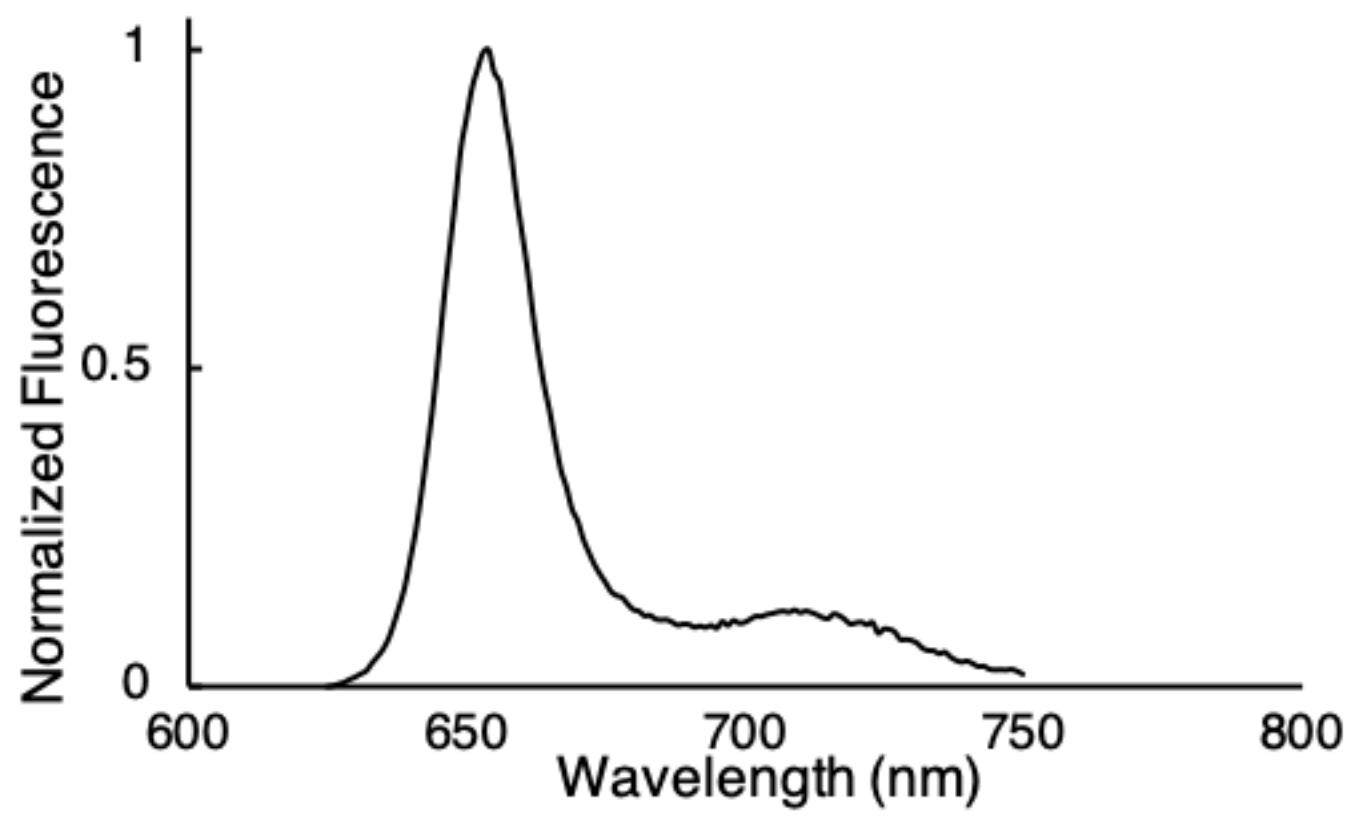

Figure S17. Fluorescence spectrum of 22 in $\mathrm{CH}_{3} \mathrm{CN}$ at room temperature. The peak fluorescence is at $654 \mathrm{~nm}$. 


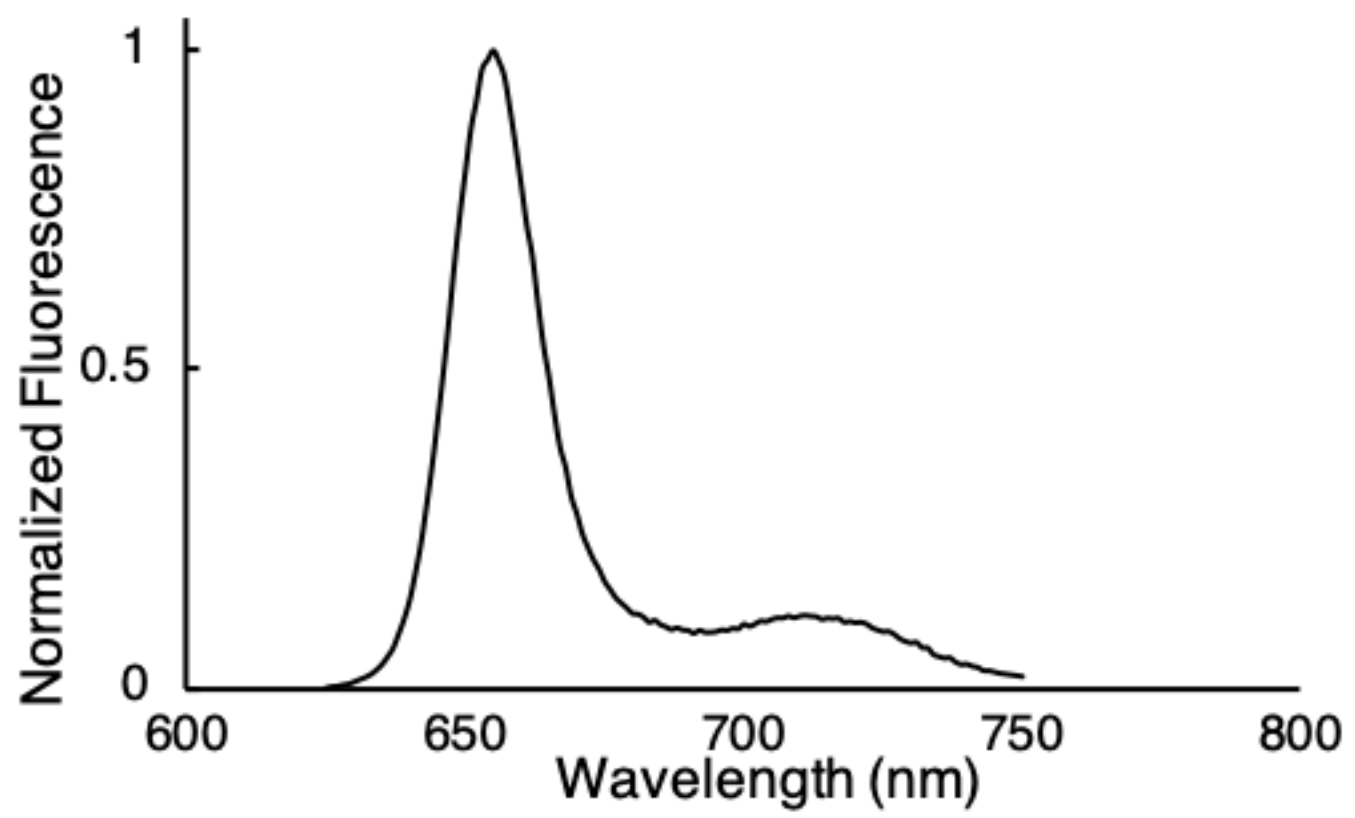

Figure S18. Fluorescence spectrum of 23 in $\mathrm{CH}_{3} \mathrm{CN}$ at room temperature. The peak fluorescence is at $655 \mathrm{~nm}$.

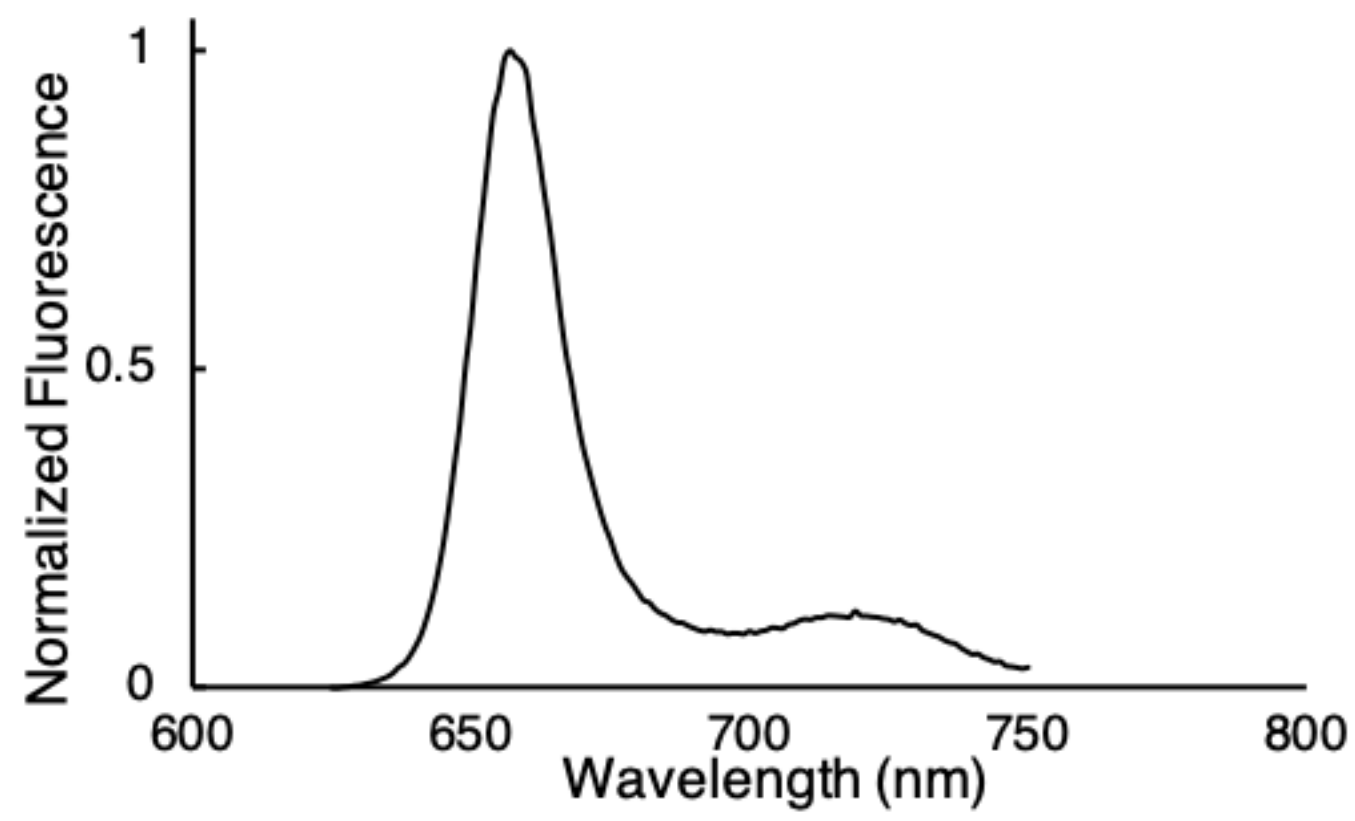

Figure S19. Fluorescence spectrum of 24 in $\mathrm{CH}_{3} \mathrm{CN}$ at room temperature. The peak fluorescence is at $657 \mathrm{~nm}$. 


\section{Single-crystal $\mathrm{X}$-ray structures}

Single crystals suitable for structure analysis were selected from the bulk and mounted on a MiTeGen mount. Data were collected on a Bruker-Nonius X8 Kappa ApexII diffractometer by $\omega$ and $\phi$ scans using MoK $\alpha$ radiation $(\lambda=0.71073 \AA)$. Corrections for Lorentz and polarization effects, and absorption were made using SADABS. ${ }^{\mathrm{S} 1}$ All structures were solved using direct methods, and refined using full-matrix least squares (on $F^{2}$ ) using the SHELXT ${ }^{\mathrm{S} 2}$ software package. All non-hydrogen atoms were refined anisotropically. Alkyl and aryl $\mathrm{H}$ atoms were added at calculated positions, with coordinates and $\mathrm{U}_{\text {iso }}$ values allowed to ride on the parent atom. $\mathrm{H}$ atoms that participate in hydrogen bonding were generally located from the electron density difference map, with their position allowed to refine freely, and riding $\mathrm{U}_{\text {iso. Structures }}$ were obtained through use of the ORTEP 3 package.

(S1) Bruker-AXS Inc. (2014), Madison Wisconsin, USA.

(S2) Sheldrick, G. M. SHELXT - Integrated space-group and crystal-structure determination. Acta Cryst. A 2015, 71, 3-8.

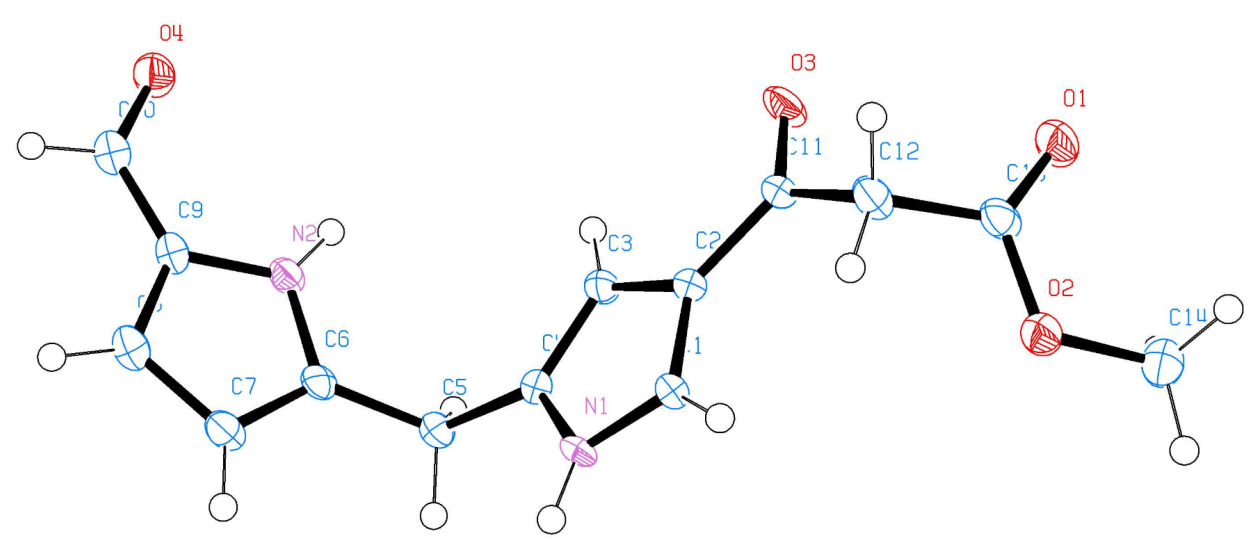

Figure S20. ORTEP diagram of compound aroylpyrroles 2 with thermal ellipsoids drawn at the $50 \%$ probability level. Crystals were grown by slow evaporation of a THF solution. 
Table S7. Data for 2.

CCDC registry

Chemical formula

Formula weight $(\mathrm{g} / \mathrm{mol})$

Temperature (K)

Wavelength $(\AA)$

Crystal size (mm)

Crystal habit

Crystal system

Space group

Unit cell dimensions, $a(\AA)$

Unit cell dimensions, $b(\AA)$

Unit cell dimensions, $c(\AA)$

$$
\begin{gathered}
\alpha, \operatorname{deg} \\
\beta, \operatorname{deg} \\
\gamma, \operatorname{deg} \\
\text { Volume }\left(\AA^{3}\right) \\
Z
\end{gathered}
$$

Density (calculated) $\left(\mathrm{g} / \mathrm{cm}^{3}\right)$

Absorption coefficient $\left(\mathrm{mm}^{-1}\right)$

$$
\mathrm{F}(000)
$$

Theta range for data collection, deg

Reflections collected

Independent reflections

$\mathrm{R}_{1}$

$w_{2}$

$\mathrm{R}_{1}$ (all data)

$\mathrm{wR}_{2}$ (all data)
1958435

$\mathrm{C}_{14} \mathrm{H}_{14} \mathrm{~N}_{2} \mathrm{O}_{4}$

274.27

$100(2)$

0.71073

$0.055 \times 0.121 \times 0.278$

Colorless plate

Triclinic

$$
P_{-1}
$$

7.3347(7)

9.2667(9)

10.0931(9)

$81.472(3)$

79.362(3)

74.830(3)

647.10(11)

2

1.408

0.105

288

2.06 to 25.03

2257

$2257[\mathrm{R}(\mathrm{int})=0.0000]$

0.0420

0.0906

0.0654

0.1011

0.269 and -0.243

0.051

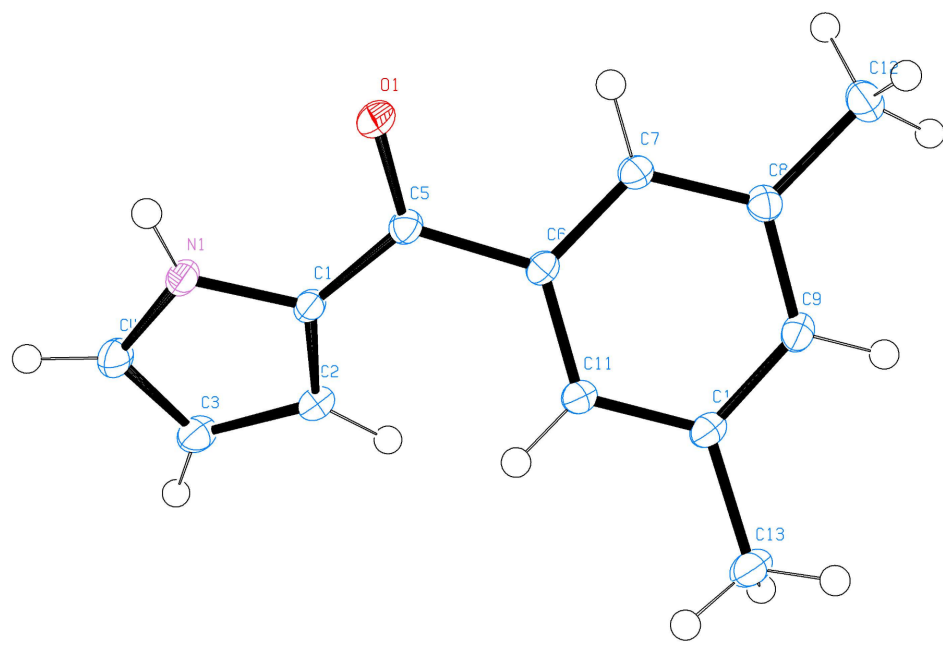

Figure S21. ORTEP diagram of compound aroylpyrroles 8 with thermal ellipsoids drawn at the $50 \%$ probability level. Crystals were grown by slow evaporation of a dichloromethane solution. 
Table S8. Data for 8 .

CCDC registry

Chemical formula

Formula weight $(\mathrm{g} / \mathrm{mol})$

Temperature (K)

Wavelength $(\AA)$

Crystal size (mm)

Crystal habit

Crystal system

Space group

Unit cell dimensions, $a(\AA)$

Unit cell dimensions, $b(\AA)$

Unit cell dimensions, $c(\AA)$

$$
\alpha, \operatorname{deg}
$$

$\beta, \operatorname{deg}$

$\gamma, \operatorname{deg}$

Volume $\left(\AA^{3}\right)$

$\mathrm{Z}$

Density (calculated) $\left(\mathrm{g} / \mathrm{cm}^{3}\right)$

Absorption coefficient $\left(\mathrm{mm}^{-1}\right)$

$$
F(000)
$$

Theta range for data collection, deg

Index ranges

Reflections collected

Independent reflections

$\mathrm{R}_{1}$

$\mathrm{wR}_{2}$

$\mathrm{R}_{1}$ (all data)

$\mathrm{wR}_{2}$ (all data)

Largest diff. peak and hole $\left(\mathrm{e} \AA^{-3}\right)$

R.M.S. deviation from mean $\left(\mathrm{e} \AA^{-3}\right)$
1958437

$\mathrm{C}_{13} \mathrm{H}_{13} \mathrm{NO}$

199.24

100(2)

0.71073

$0.142 \times 0.376 \times 0.380$

Colorless plate

Monoclinic

$P 2{ }_{1} / \mathrm{n}$

$11.0874(10)$

$7.3311(6)$

13.1798(12)

90

$99.6754(19)$

90

1056.05(16)

4

1.253

0.079

424

2.22 to 35.02

$-17<=\mathrm{h}<=17,-11<=\mathrm{k}<=11,-21<=1<=21$

27626

$4649[\mathrm{R}(\mathrm{int})=0.0378]$

0.0460

0.1192

0.0643

0.1319

0.566 and -0.275

0.062 

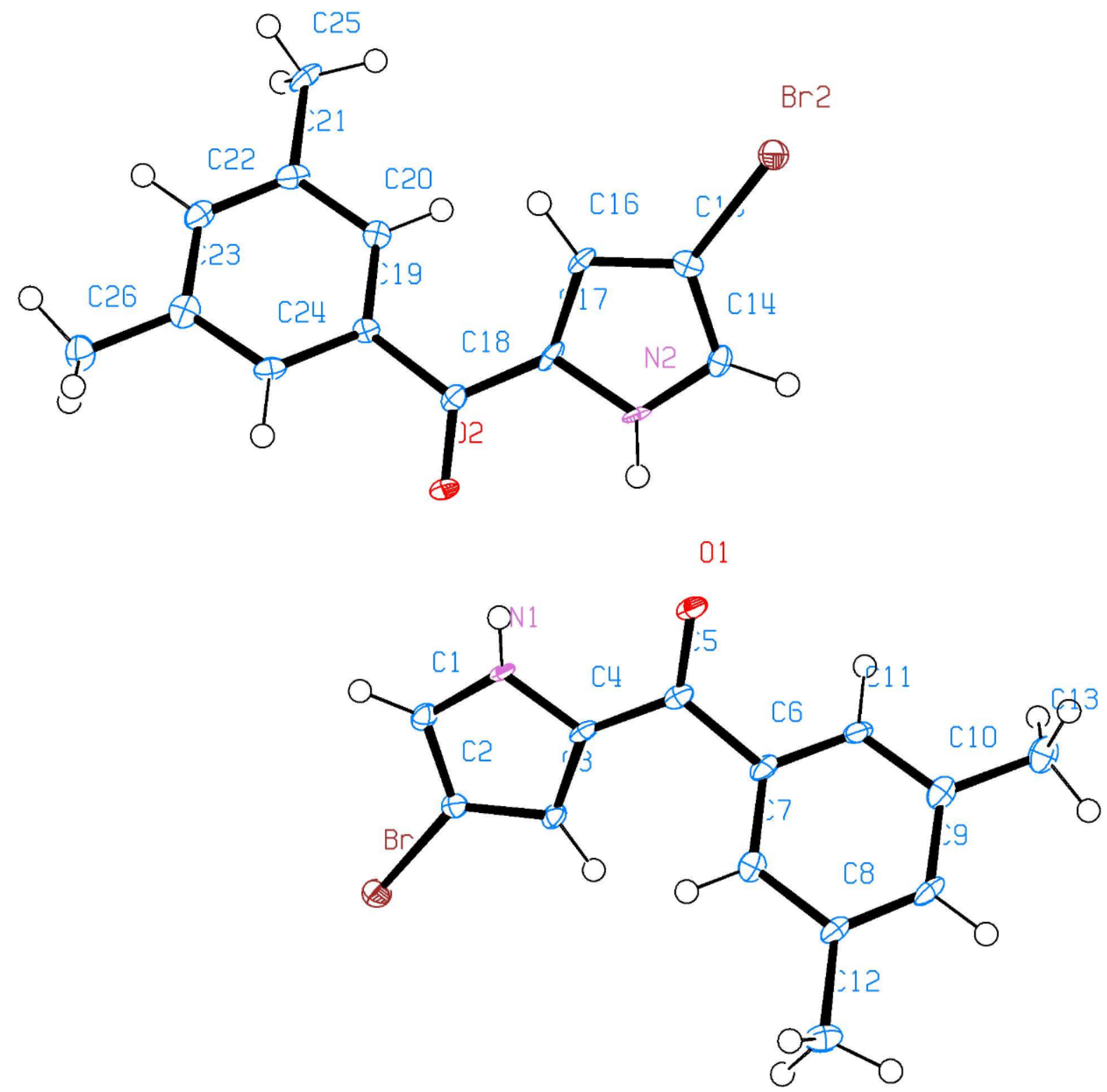

Figure S22. ORTEP diagram of compound 9-Br with thermal ellipsoids drawn at the 50\% probability level. Crystals were grown by slow evaporation of a dichloromethane solution. 
Table S9. Data for 9-Br.

CCDC registry

Chemical formula

Formula weight $(\mathrm{g} / \mathrm{mol})$

Temperature (K)

Wavelength $(\AA)$

Crystal size (mm)

Crystal habit

Crystal system

Space group

Unit cell dimensions, $a(\AA)$

Unit cell dimensions, $b(\AA)$

Unit cell dimensions, $c(\AA)$

$$
\alpha, \operatorname{deg}
$$

$\beta, \operatorname{deg}$

$\gamma, \operatorname{deg}$

Volume $\left(\AA^{3}\right)$

$\mathrm{Z}$

Density (calculated) $\left(\mathrm{g} / \mathrm{cm}^{3}\right)$

Absorption coefficient $\left(\mathrm{mm}^{-1}\right)$

$\mathrm{F}(000)$

Theta range for data collection, deg

Index ranges

Reflections collected

Independent reflections

Max. and min. transmission

$$
\mathrm{R}_{1}
$$

$\mathrm{wR}_{2}$

$\mathrm{R}_{1}$ (all data)

$\mathrm{wR}_{2}$ (all data)

Largest diff. peak and hole $\left(\mathrm{e} \AA^{-3}\right)$
1958436

$\mathrm{C}_{13} \mathrm{H}_{12} \mathrm{BrNO}$

278.15

100

0.71073

$0.037 \times 0.047 \times 0.0161$

Colorless needle

orthorhombic

P 212121

$3.9928(2)$

20.0972(6)

28.7175(10)

90

90

90

2304.41(16)

8

1.603

3.544

1120.0

1.42 to 25.41

$-4<=\mathrm{h}<=4,-16<=\mathrm{k}<=24,-34<=1<=34$

16291

$4241[\mathrm{R}(\mathrm{int})=0.0579]$

0.8800 and 0.5990

0.0352

0.0684

0.0473

0.0721

0.724 and -0.583

0.092 


\section{IR spectra}
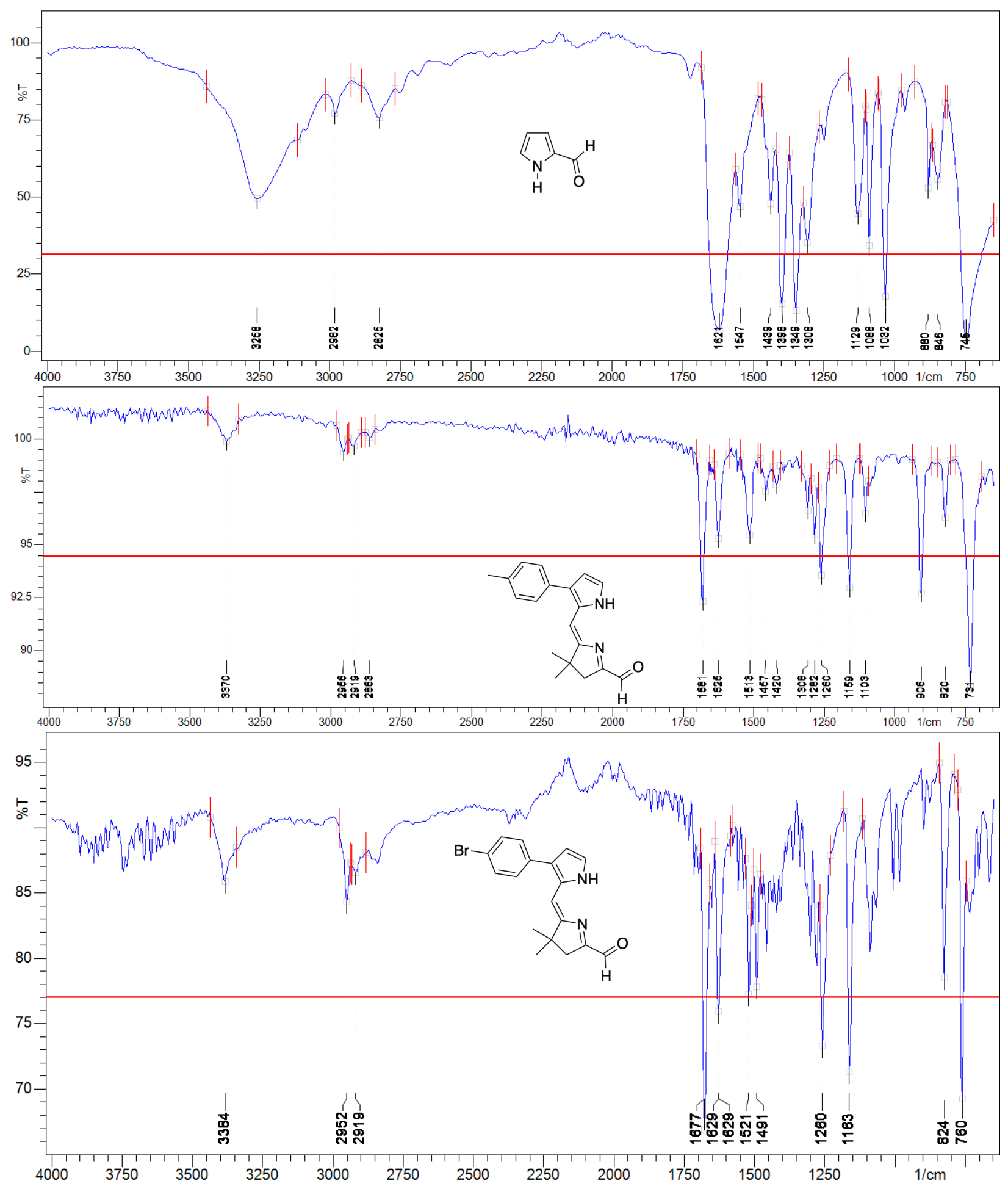

Figure S23. IR spectra of pyrrole-2-carboxaldehyde (top), AD half 17 (mid) and AD half $\mathbf{1 8}$ (bottom). 


\section{2D NOESY spectrum}

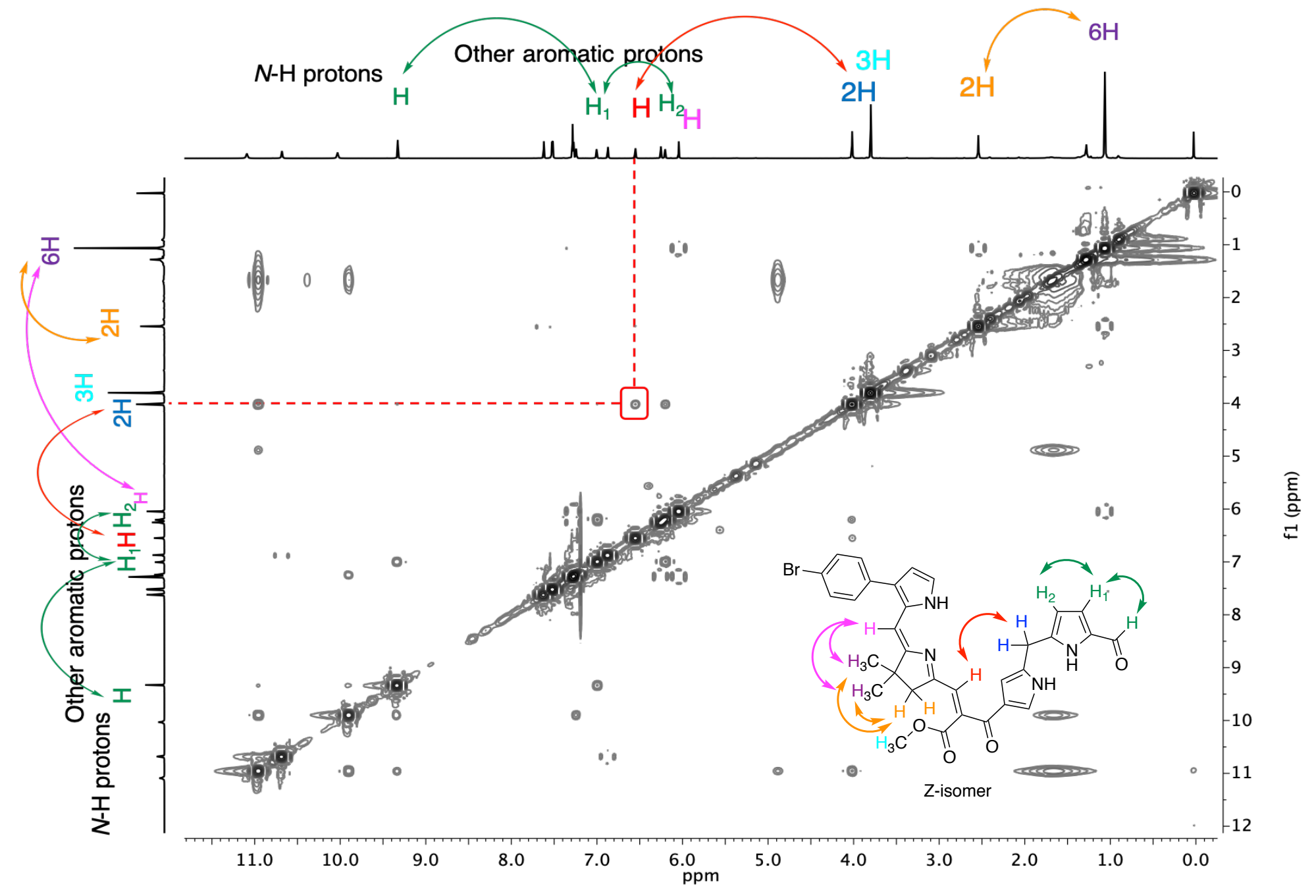

Figure S24. 2D NOESY spectrum of $\boldsymbol{Z}-20$. 


\section{Calculated conformations and distance measurements}

The $Z$ and $E$-isomer structures of $\mathbf{2 0}$ were drawn in Chemdraw 17.1 and then were opened in Chemdraw 3D Pro 13.0. Calculated conformations were obtained by the program "MM2 minimize" and saved as a pse file, which was then opened in PyMol to measure interatomic distances.

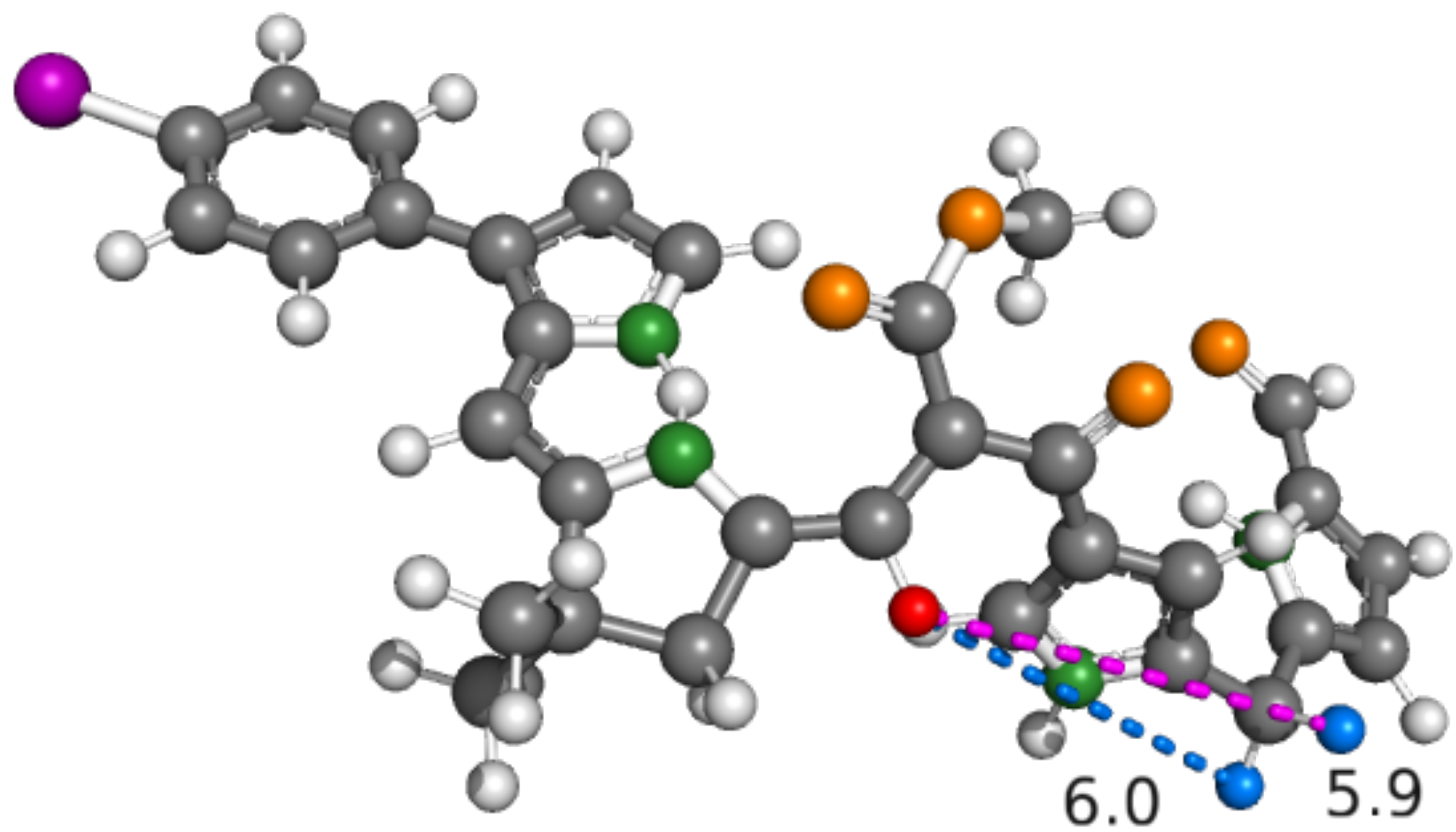




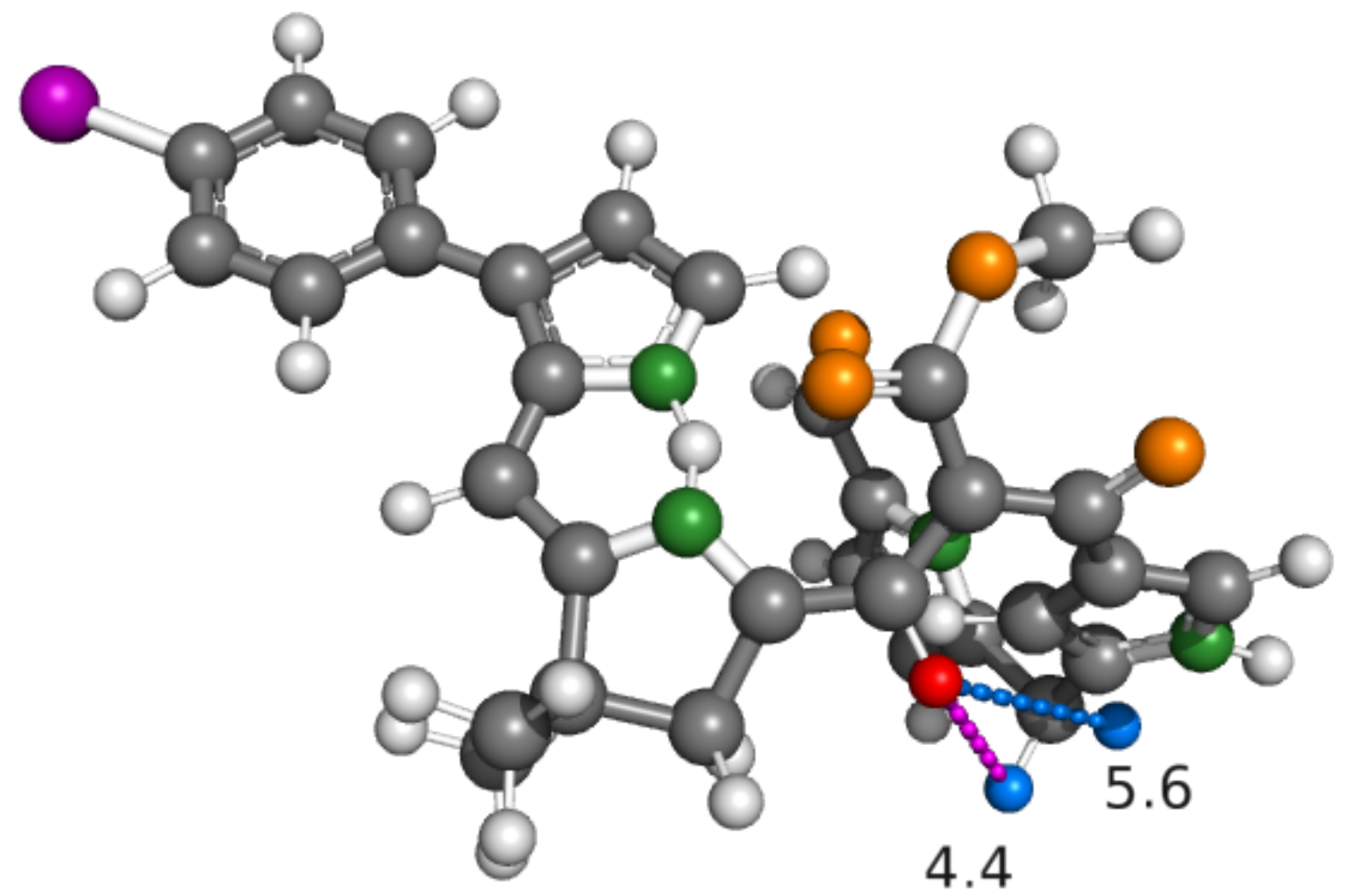

Figure S25. Calculated conformation of $(\boldsymbol{Z})-\mathbf{2 0}$ and the distance between the vinyl proton (red) and meso-protons (blue) of the dipyrromethane (top, $5.9 \AA$ and $6.0 \AA$; bottom, $5.6 \AA$ and $4.4 \AA$ ). Carbon (gray), hydrogen (white), oxygen (orange) and bromine (purple) are displayed. Note: intramolecular hydrogen bonding was introduced to planarize the dipyrrin (AD half) of the model. 


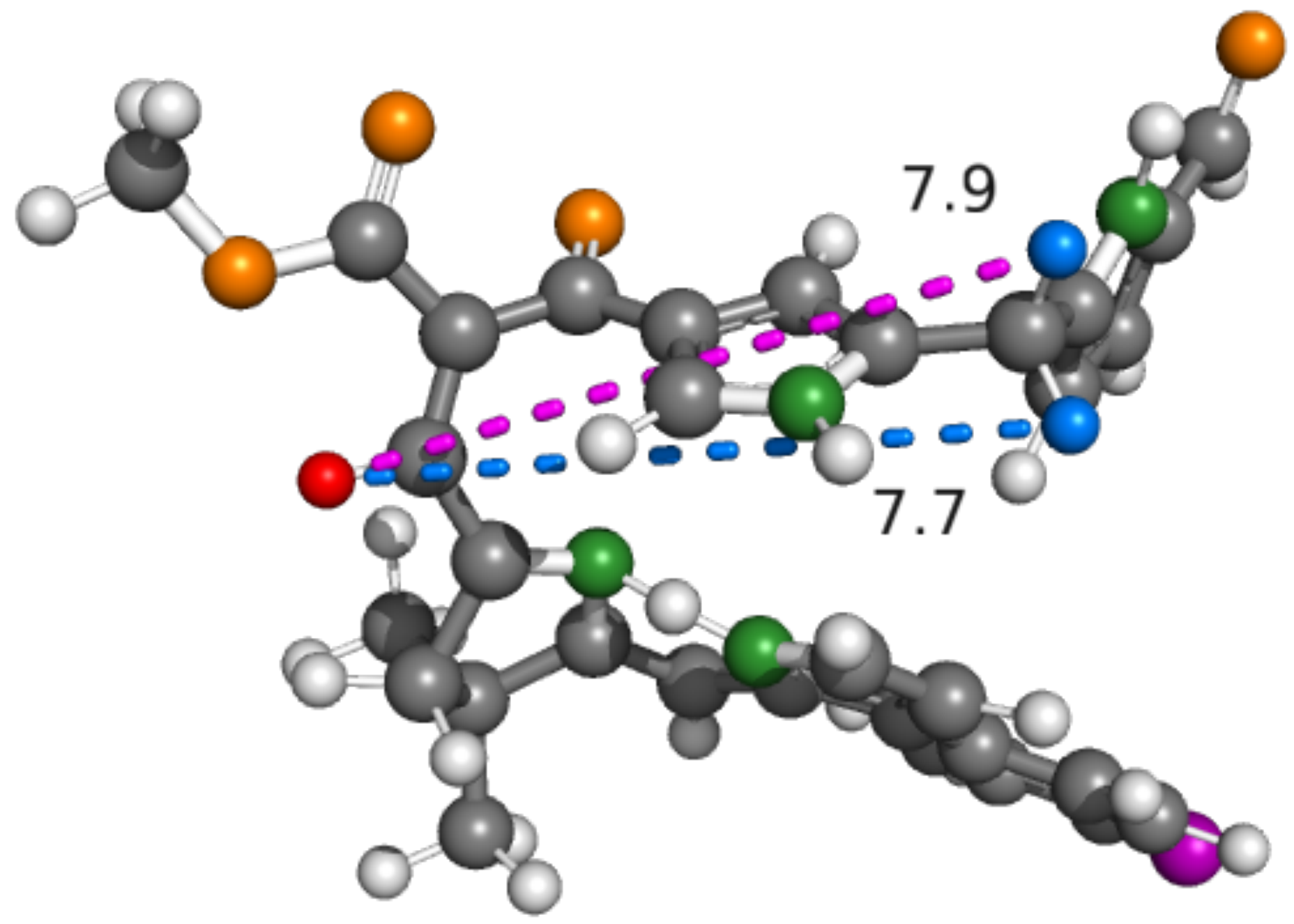




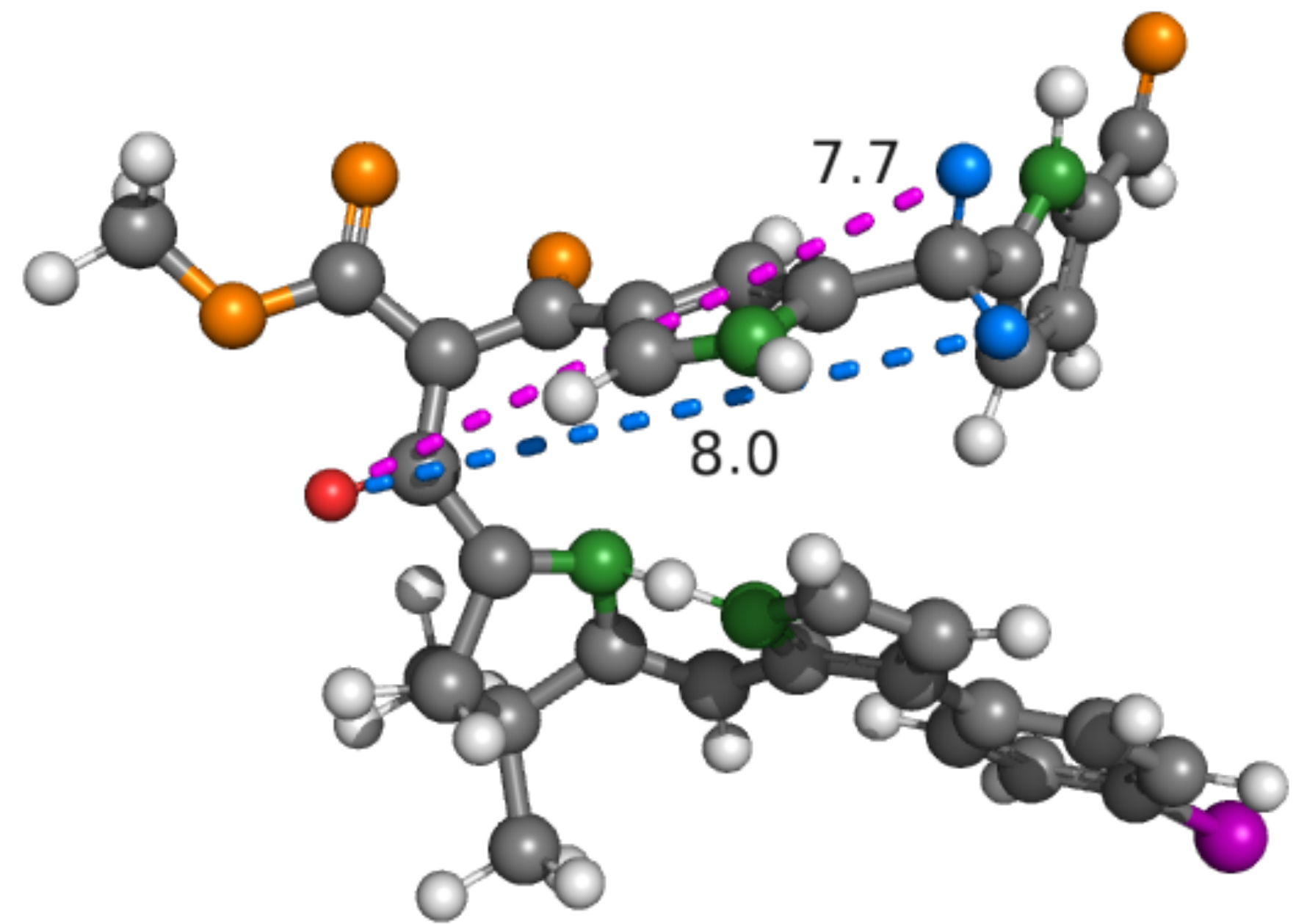

Figure S26. Calculated conformation of $(\boldsymbol{E})-\mathbf{2 0}$ and the distance between the vinyl proton (red) and meso-protons (blue) of the dipyrromethane (top, $7.7 \AA$ and $7.9 \AA$; bottom, $7.7 \AA$ and $8.0 \AA$ ). Carbon (gray), hydrogen (white), oxygen (orange) and bromine (purple) are displayed. Note: intramolecular hydrogen bonding was introduced to planarize the dipyrrin (AD half) of the model. 
Table S10. Data for (Z)-20.

\begin{tabular}{|c|c|c|c|}
\hline \multicolumn{2}{|c|}{$(\boldsymbol{Z})-20$ (top in figure S25) } & \multicolumn{2}{c|}{$(\boldsymbol{Z})-20$ (bottom in figure S25) } \\
\hline Iteration number & 2719 & Iteration number & 2767 \\
\hline Stretch & 4.2065 & Stretch & 4.2761 \\
\hline Bend & 83.1281 & Bend & 83.4765 \\
\hline Stretch-Bend & -0.0172 & Stretch-Bend & -0.0132 \\
\hline Torsion & 68.4998 & Torsion & 67.8422 \\
\hline Non-1,4 VDW & -4.0323 & Non-1,4 VDW & -2.1377 \\
\hline 1,4 VDW & 31.1986 & 1,4 VDW & 31.2800 \\
\hline Dipole/Dipole & 13.5331 & Dipole/Dipole & 13.6725 \\
\hline Total Energy (kcal/mol) & 196.5166 & Total Energy (kcal/mol) & 198.3963 \\
\hline
\end{tabular}

Table S11. Data for $(E)-20$.

\begin{tabular}{|c|c|c|c|}
\hline \multicolumn{2}{|c|}{$(\boldsymbol{E}) \mathbf{2 0}$ (top in figure S26) } & \multicolumn{2}{c|}{$(\boldsymbol{E})-20$ (bottom in figure S26) } \\
\hline Iteration number & 3085 & Iteration number & 3252 \\
\hline Stretch & 3.9726 & Stretch & 3.9685 \\
\hline Bend & 78.3689 & Bend & 78.3601 \\
\hline Stretch-Bend & -0.6776 & Stretch-Bend & -0.6800 \\
\hline Torsion & 71.2756 & Torsion & -11.2312 \\
\hline Non-1,4 VDW & -11.2916 & Non-1,4 VDW & 33.3793 \\
\hline 1,4 VDW & 33.3839 & 1,4 VDW & 8.5009 \\
\hline Dipole/Dipole & 8.5445 & Dipole/Dipole & 183.5674 \\
\hline Total Energy (kcal/mol) & 183.5763 & Total Energy (kcal/mol) & \\
\hline
\end{tabular}


7. ${ }^{1} \mathrm{H}$ NMR and ${ }^{13} \mathrm{C}$ NMR spectra
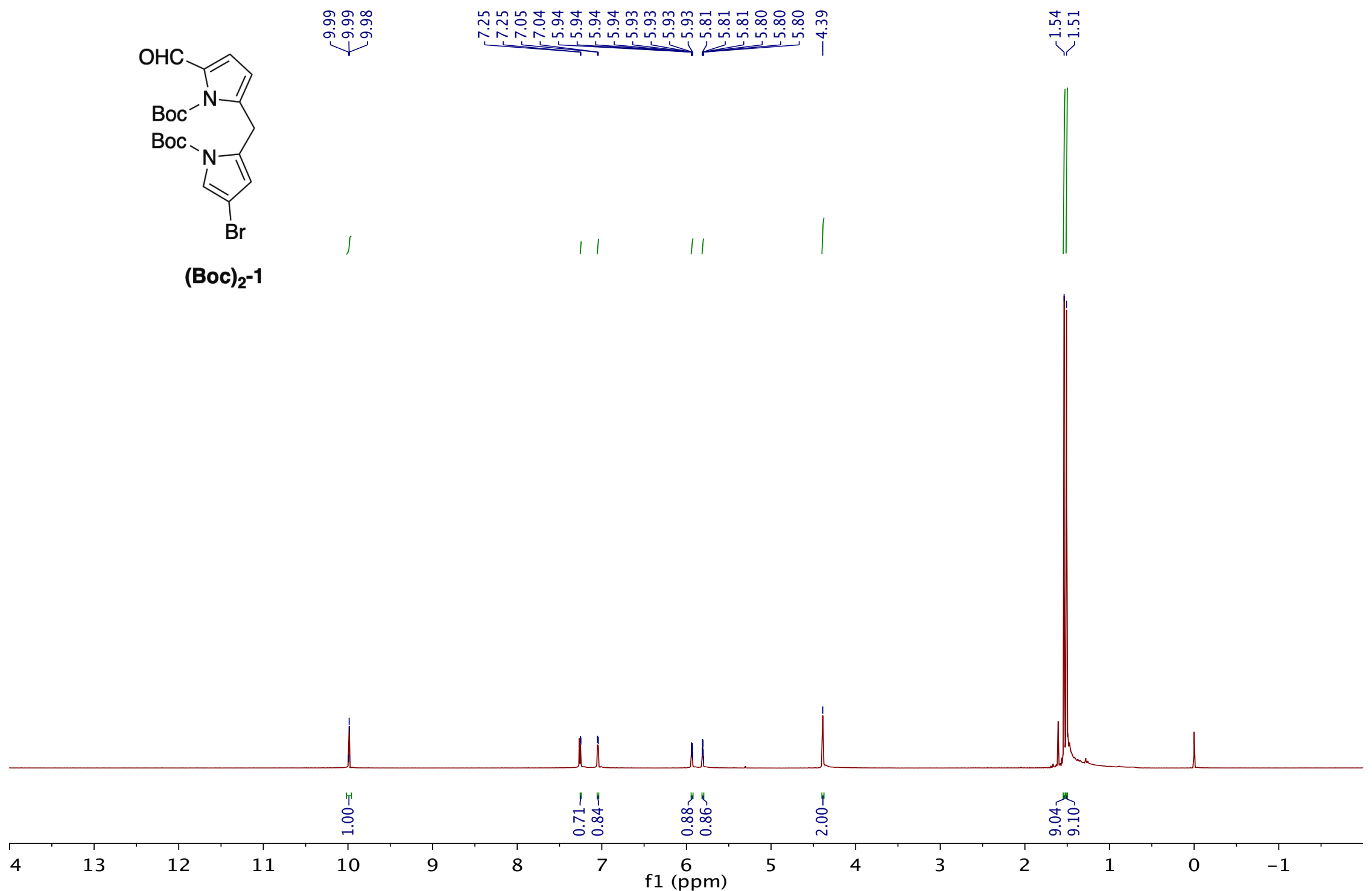

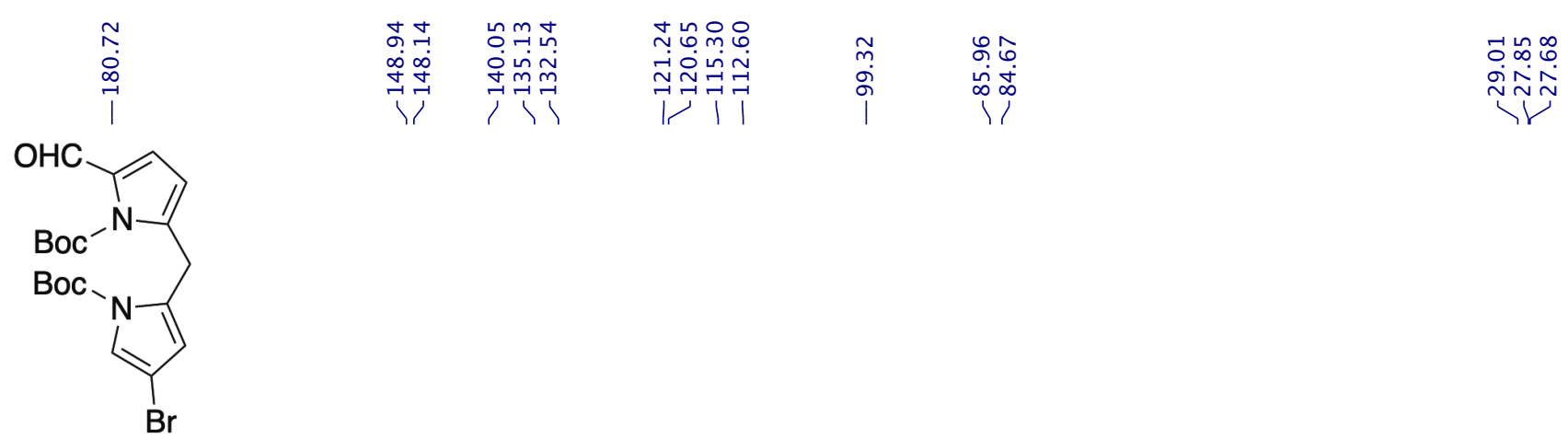

(Boc) $)_{2}-1$

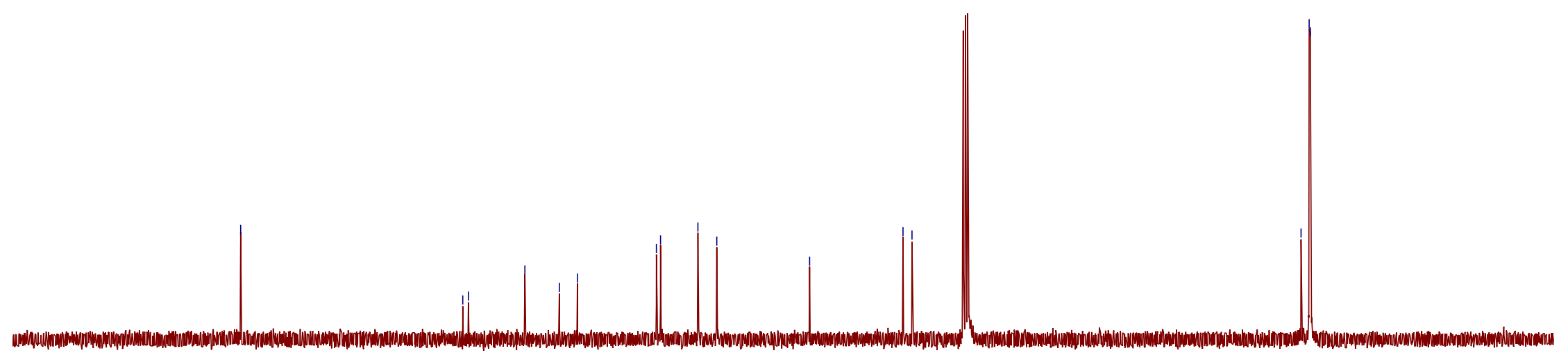

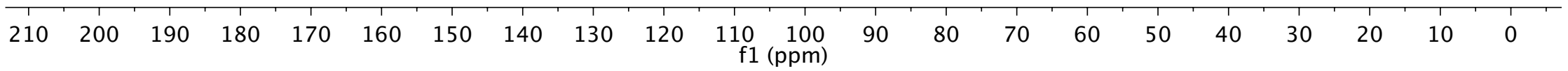




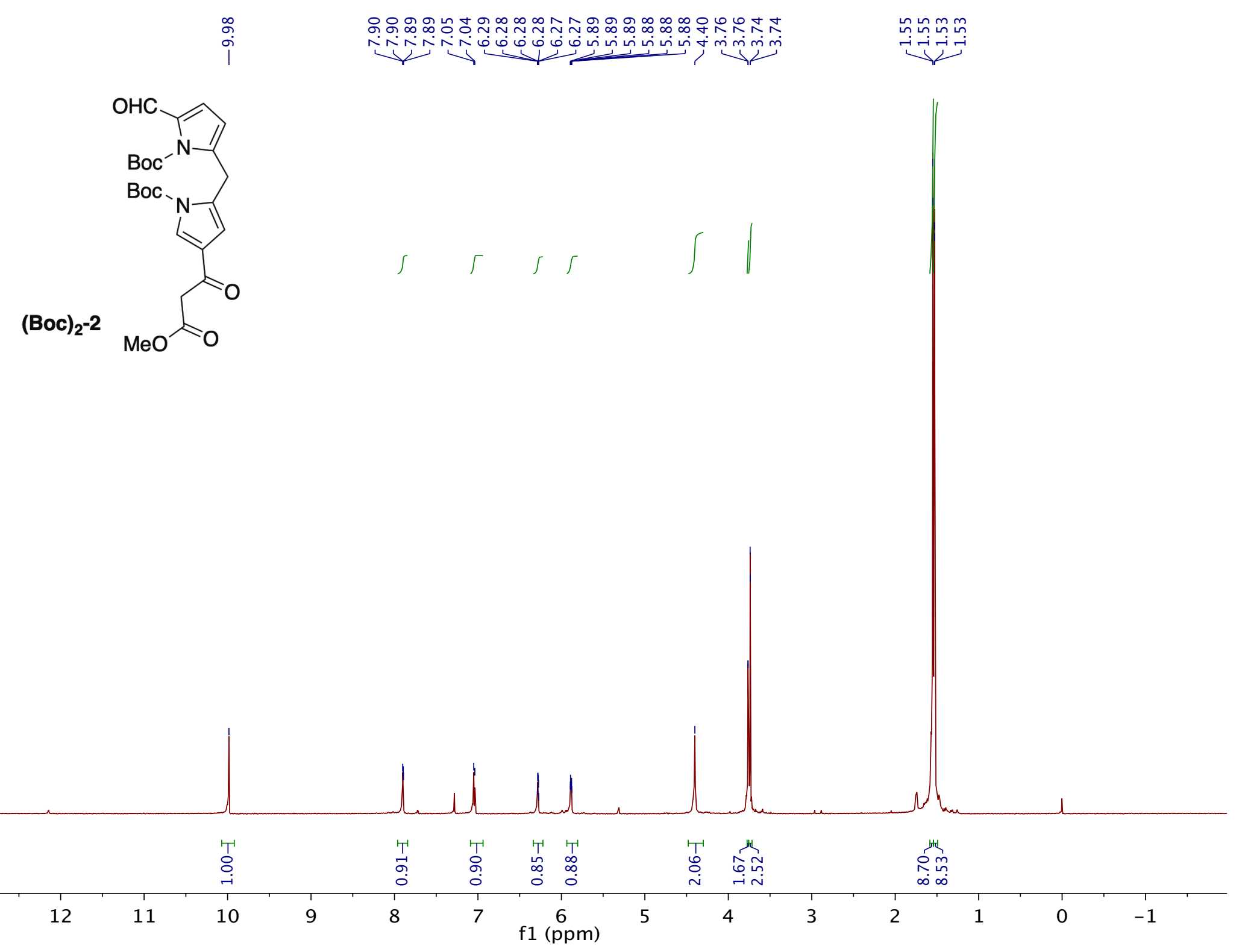




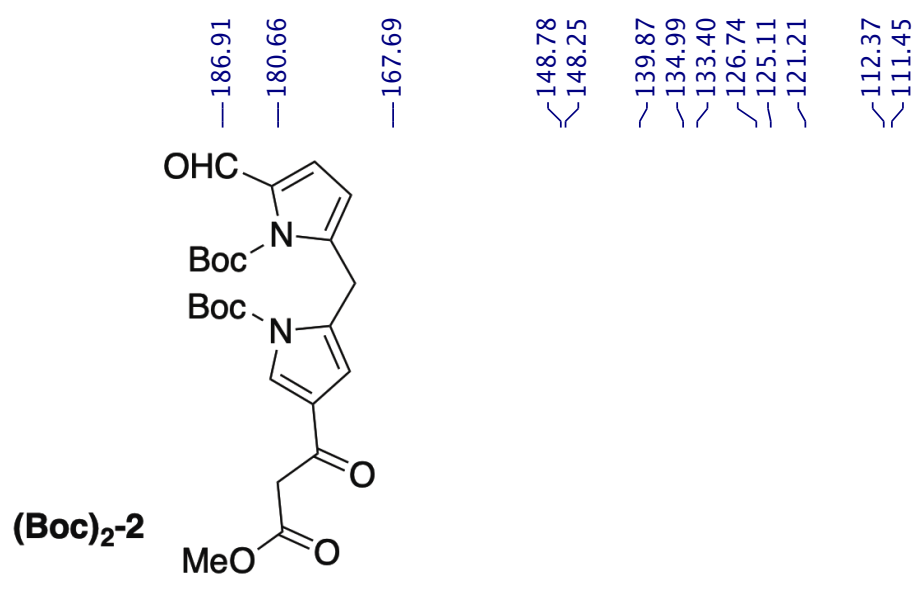

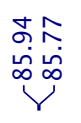

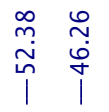

웅

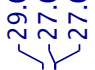

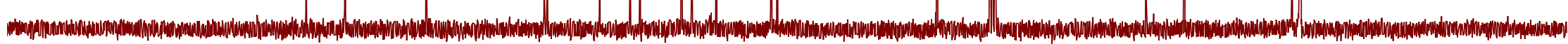

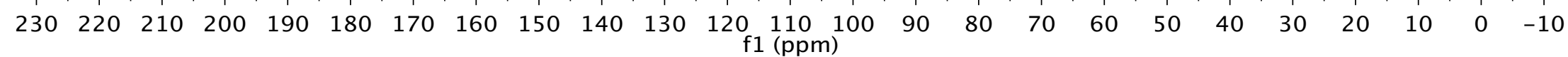




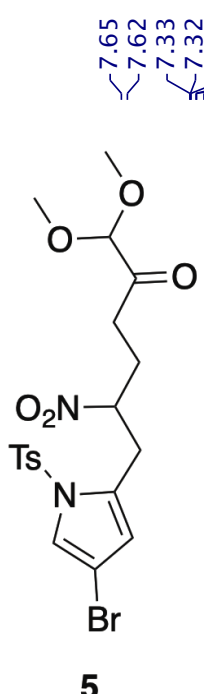

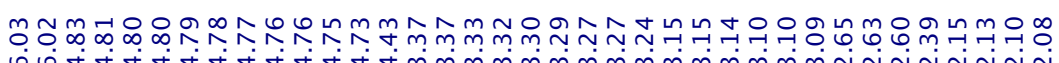

முن

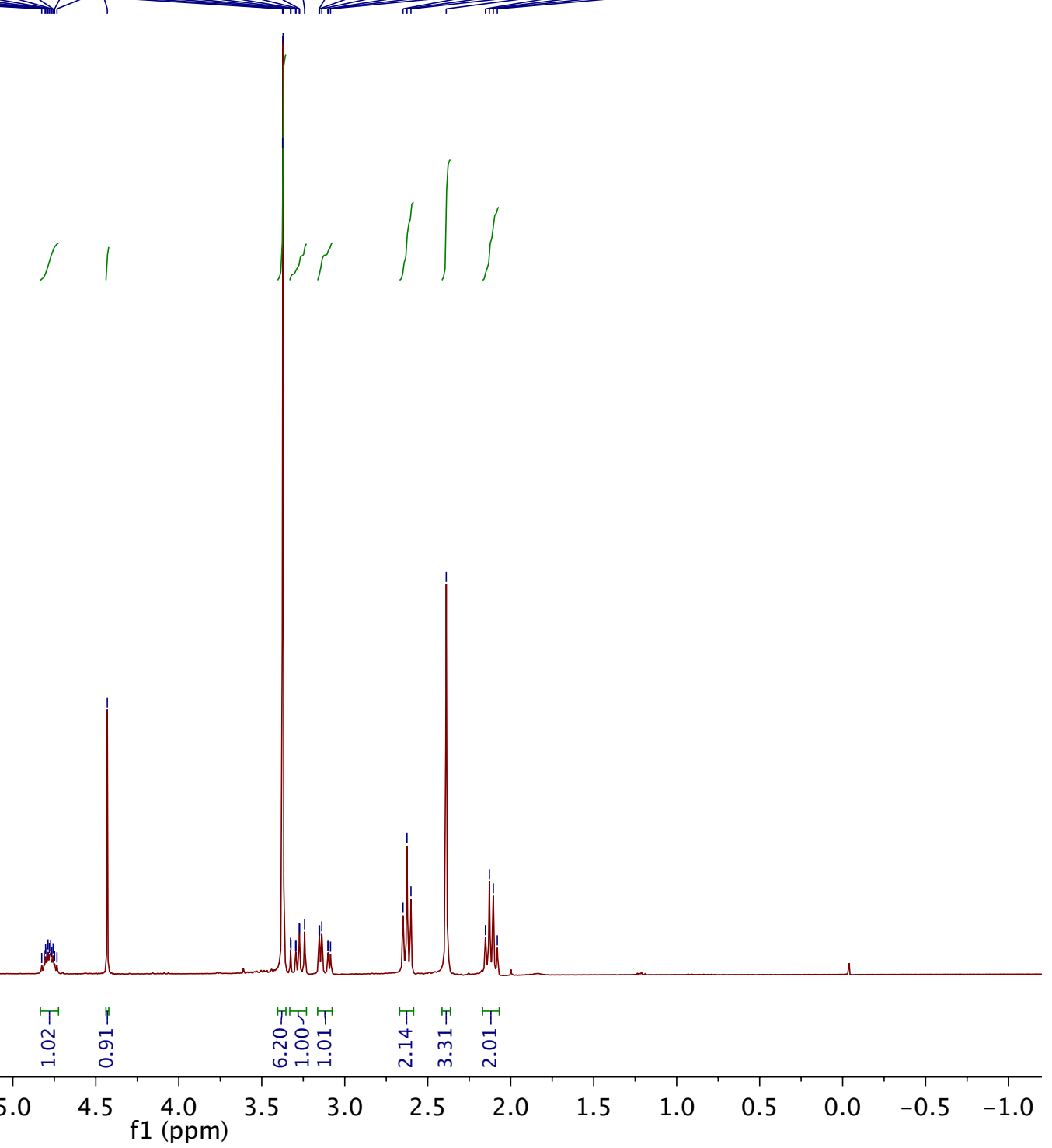




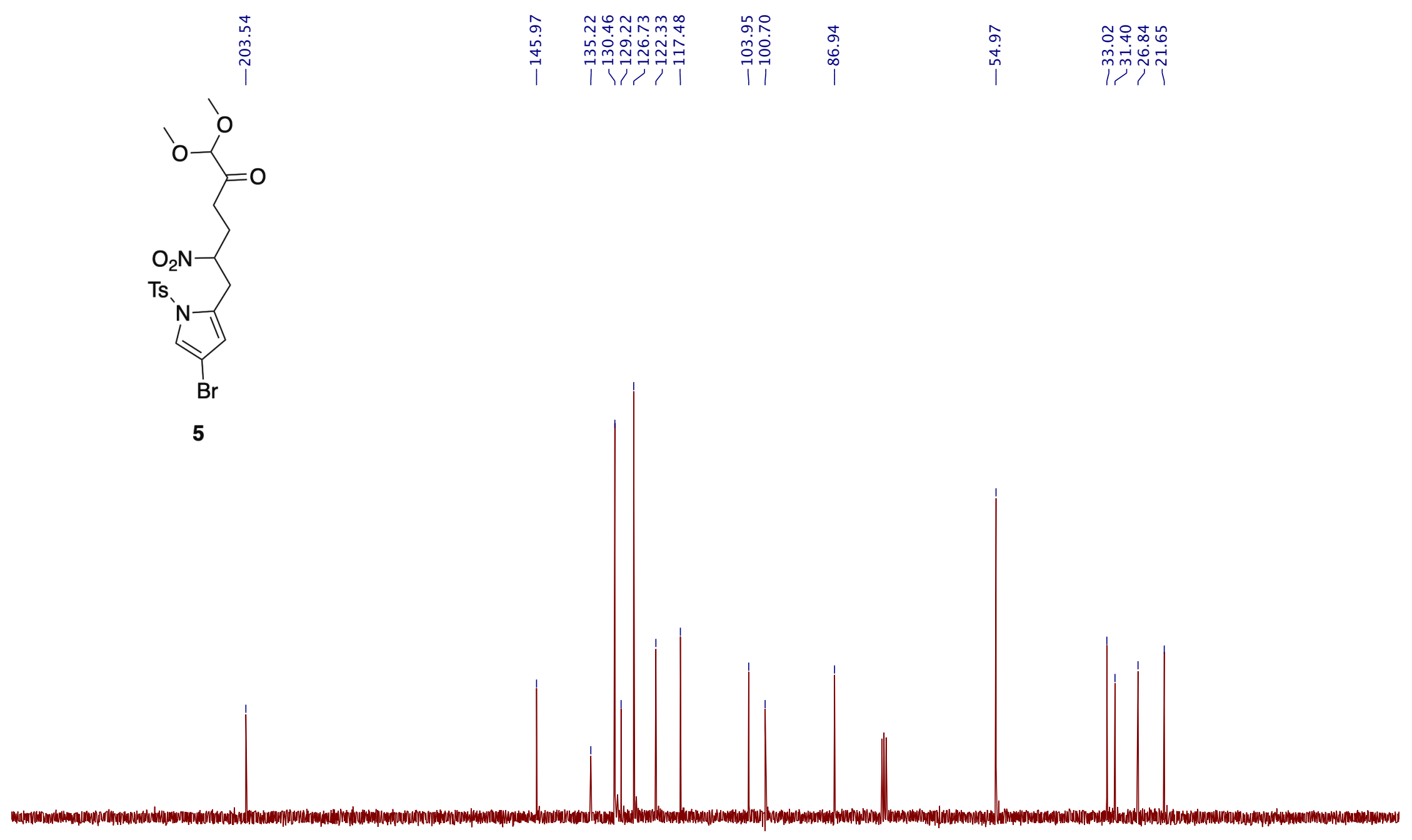

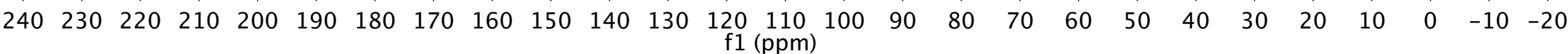




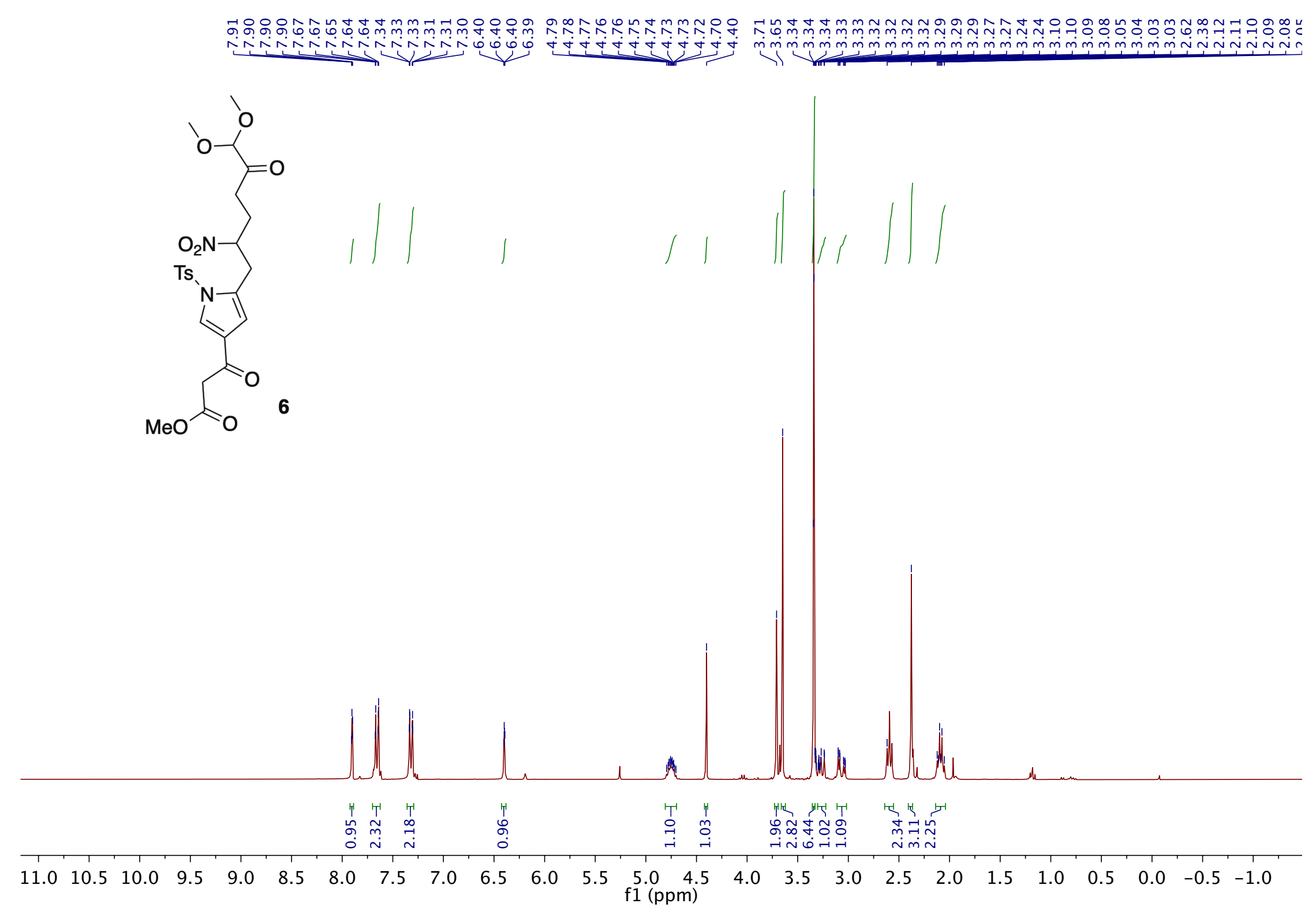




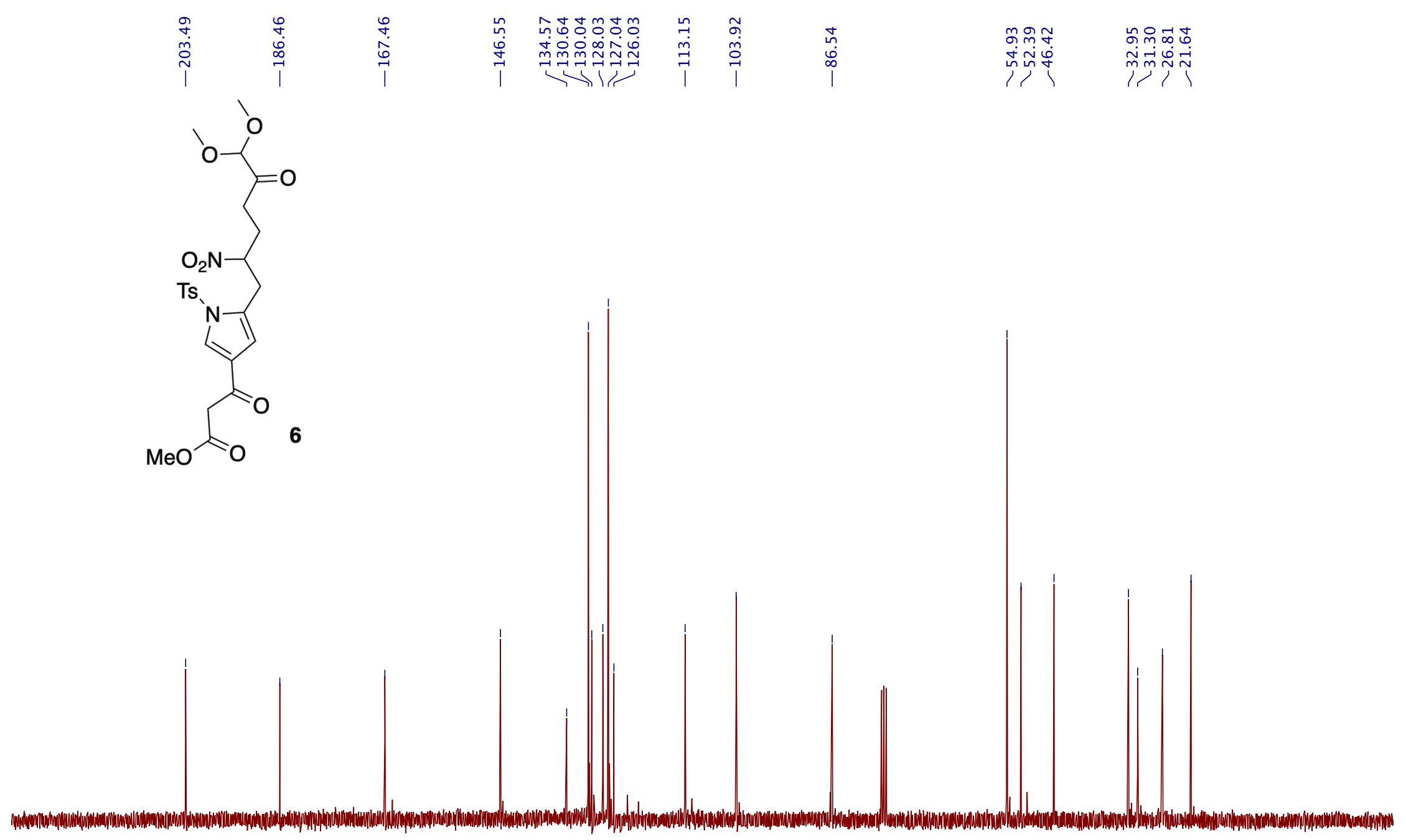

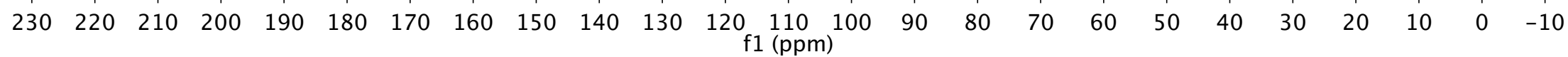




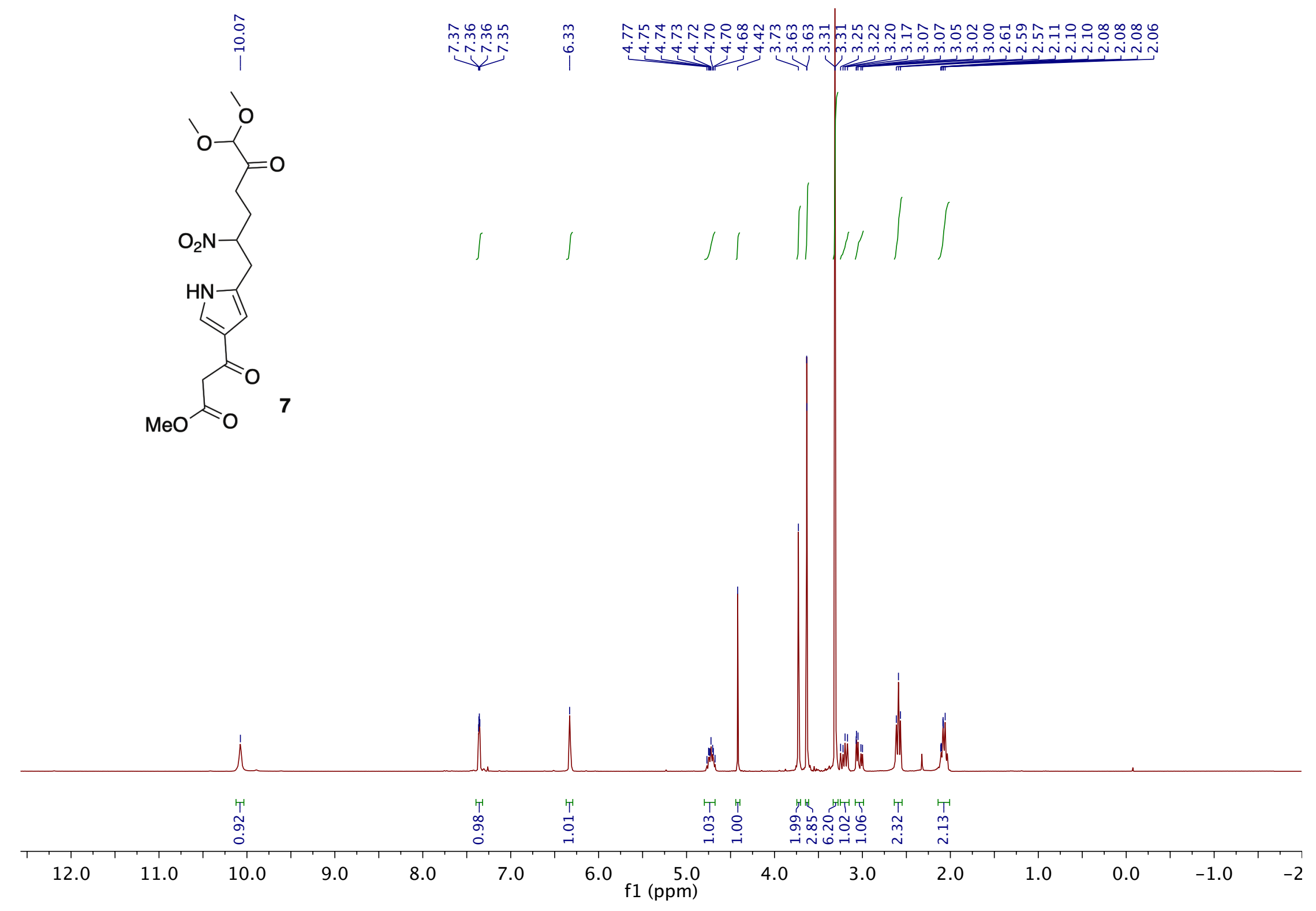



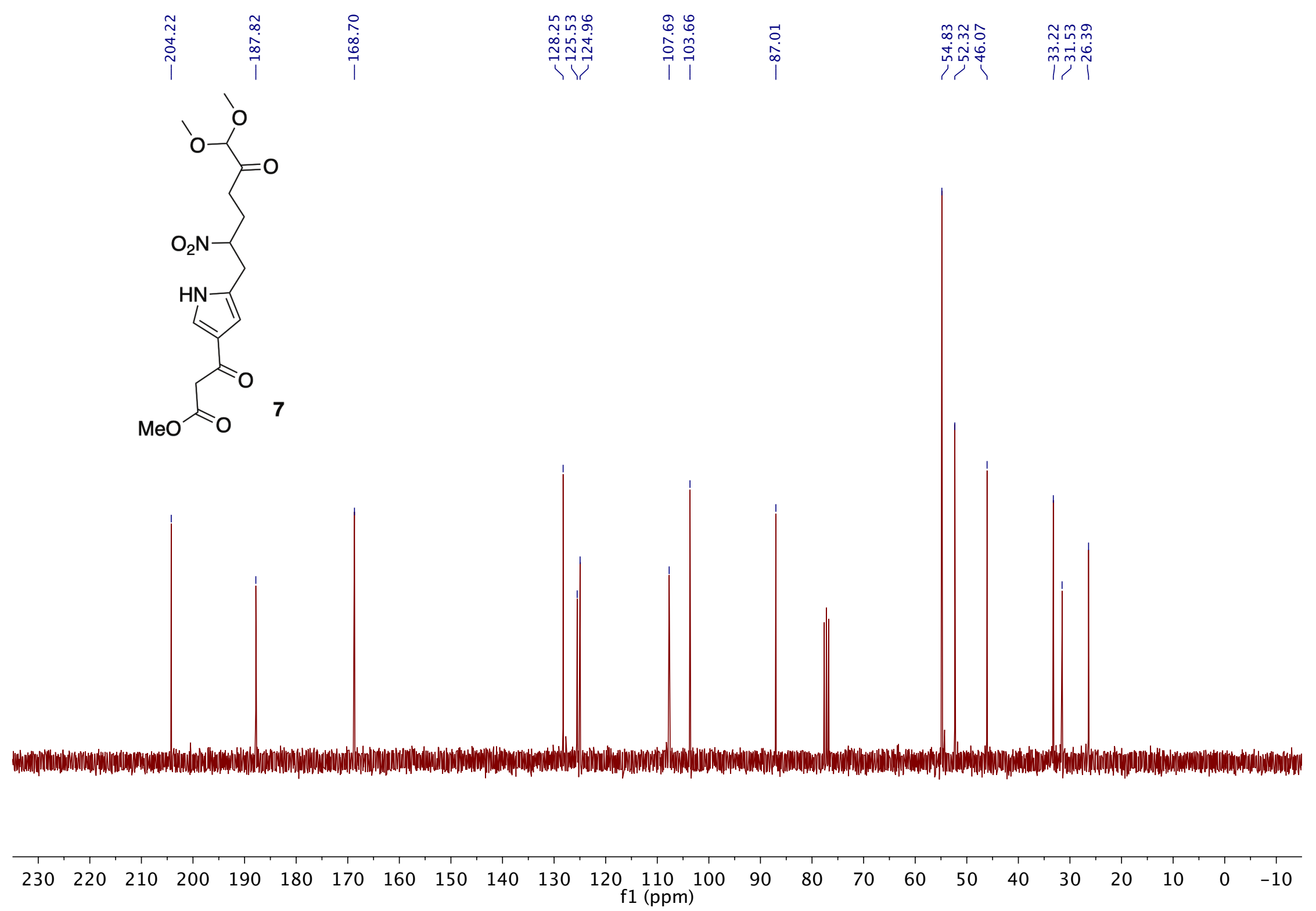


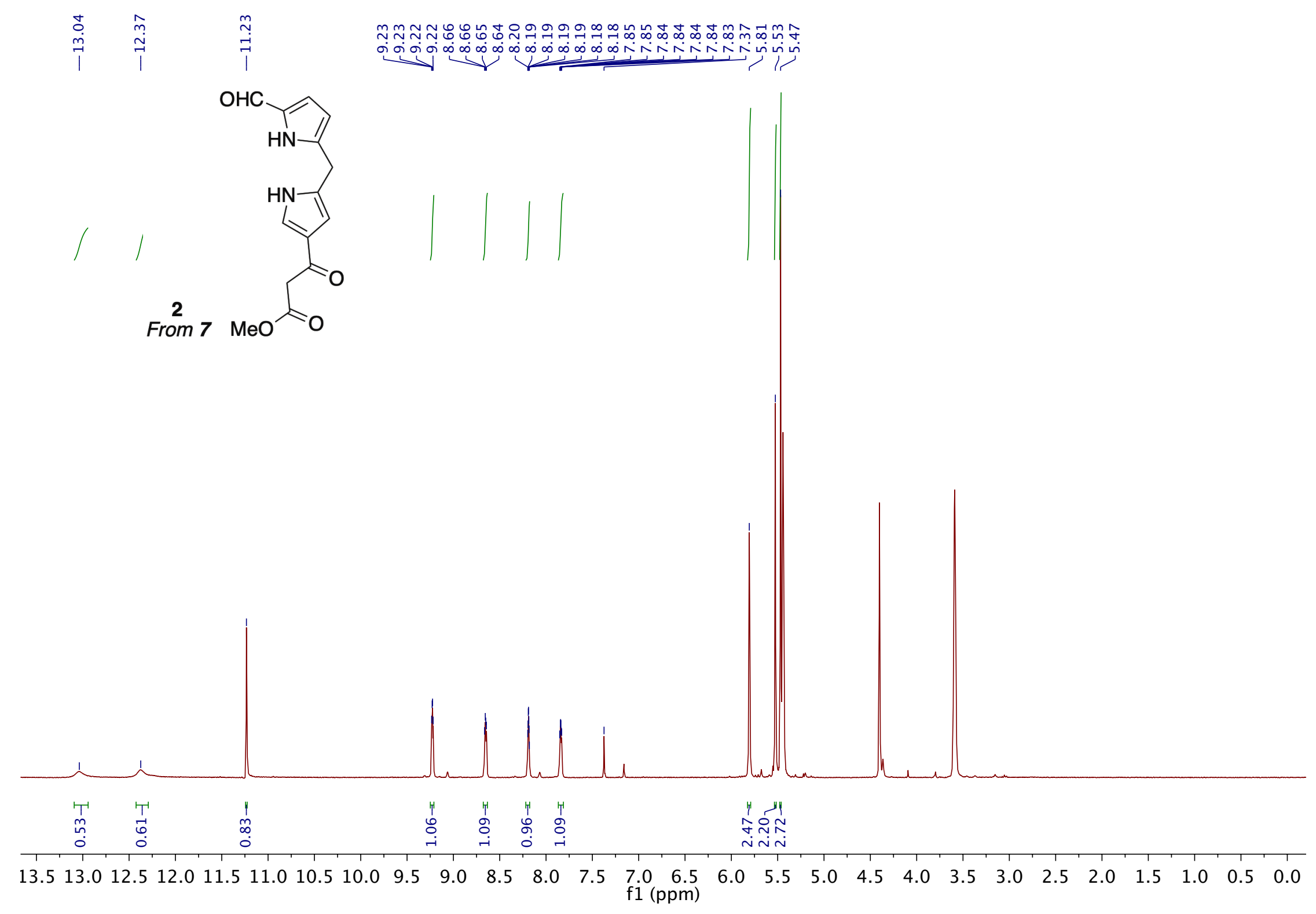




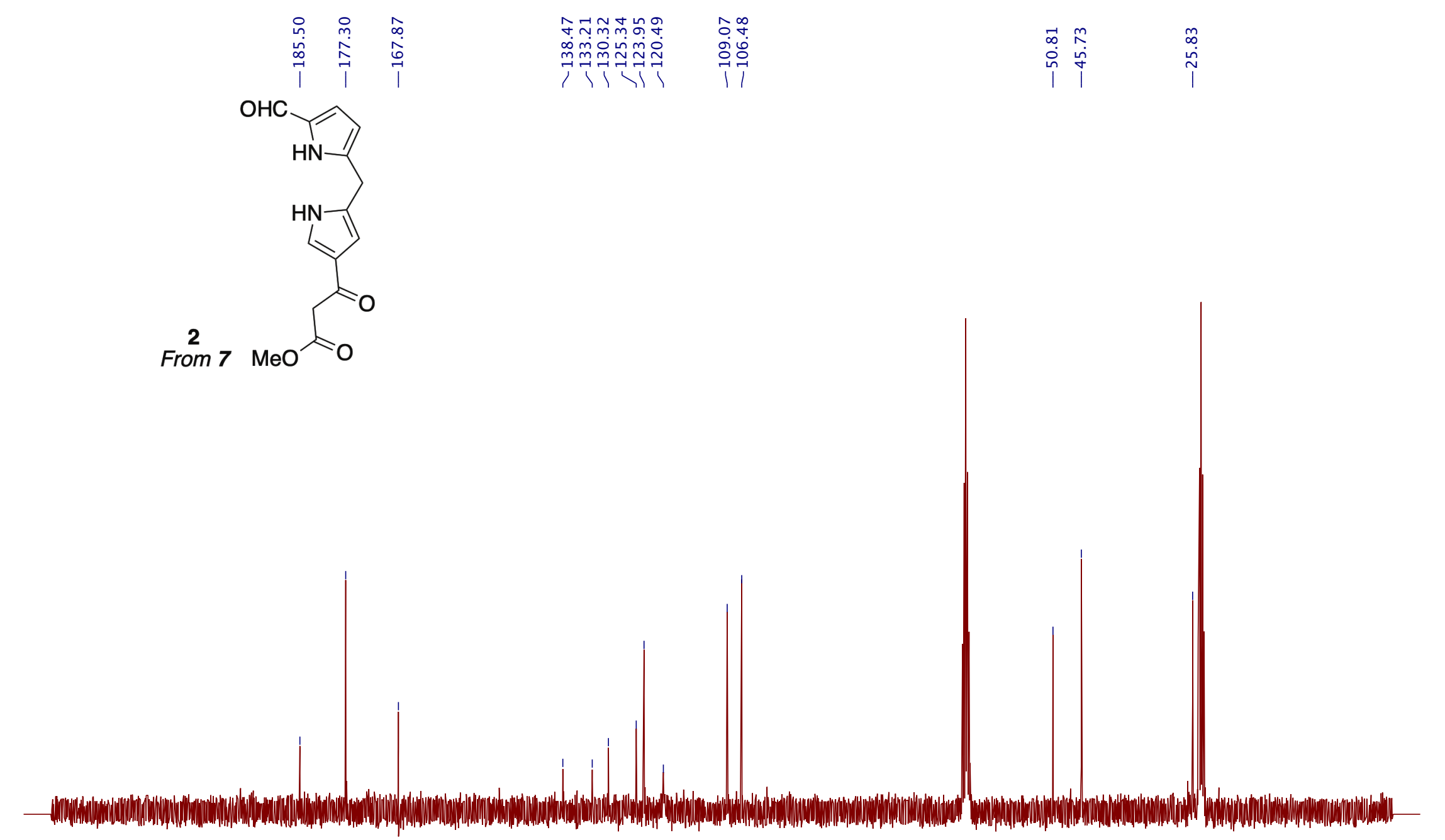

$\begin{array}{lllllllllllllllllllllllll}230 & 220 & 210 & 200 & 190 & 180 & 170 & 160 & 150 & 140 & 130 & 120 & \begin{array}{l}110 \\ \mathrm{f} 1(\mathrm{ppm})\end{array} & 100 & 90 & 80 & 70 & 60 & 50 & 40 & 30 & 20 & 10 & 0 & -10\end{array}$ 

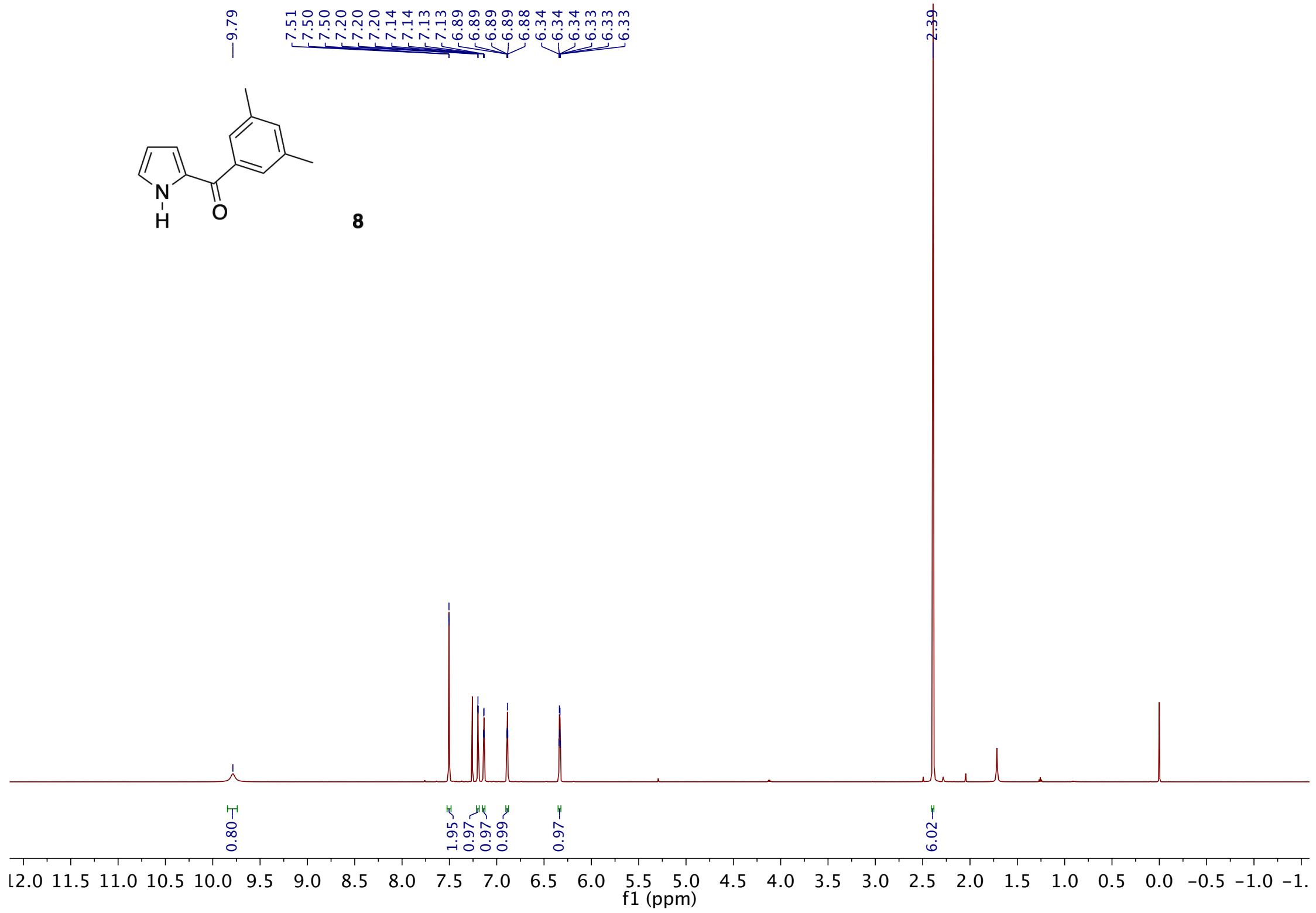


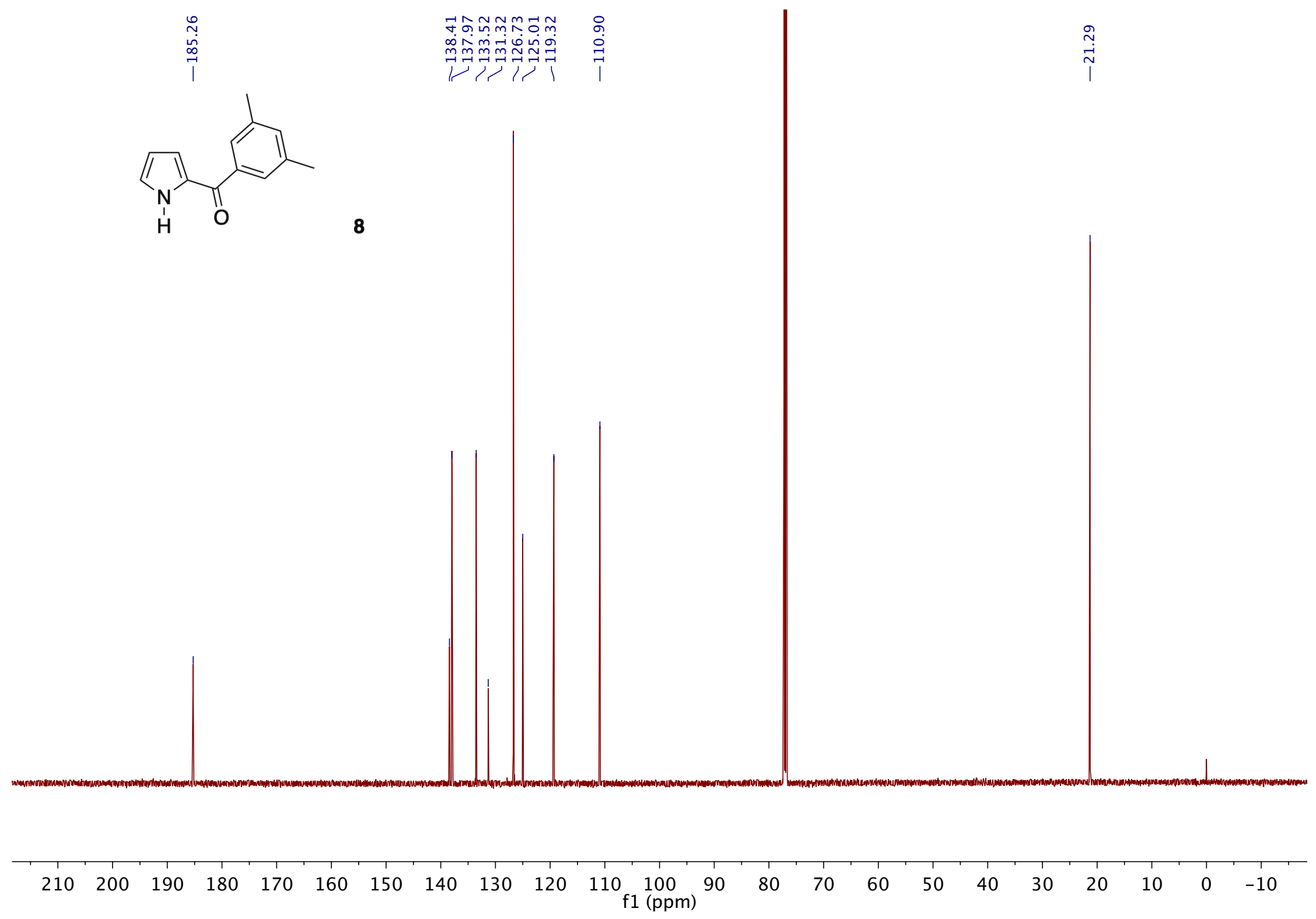




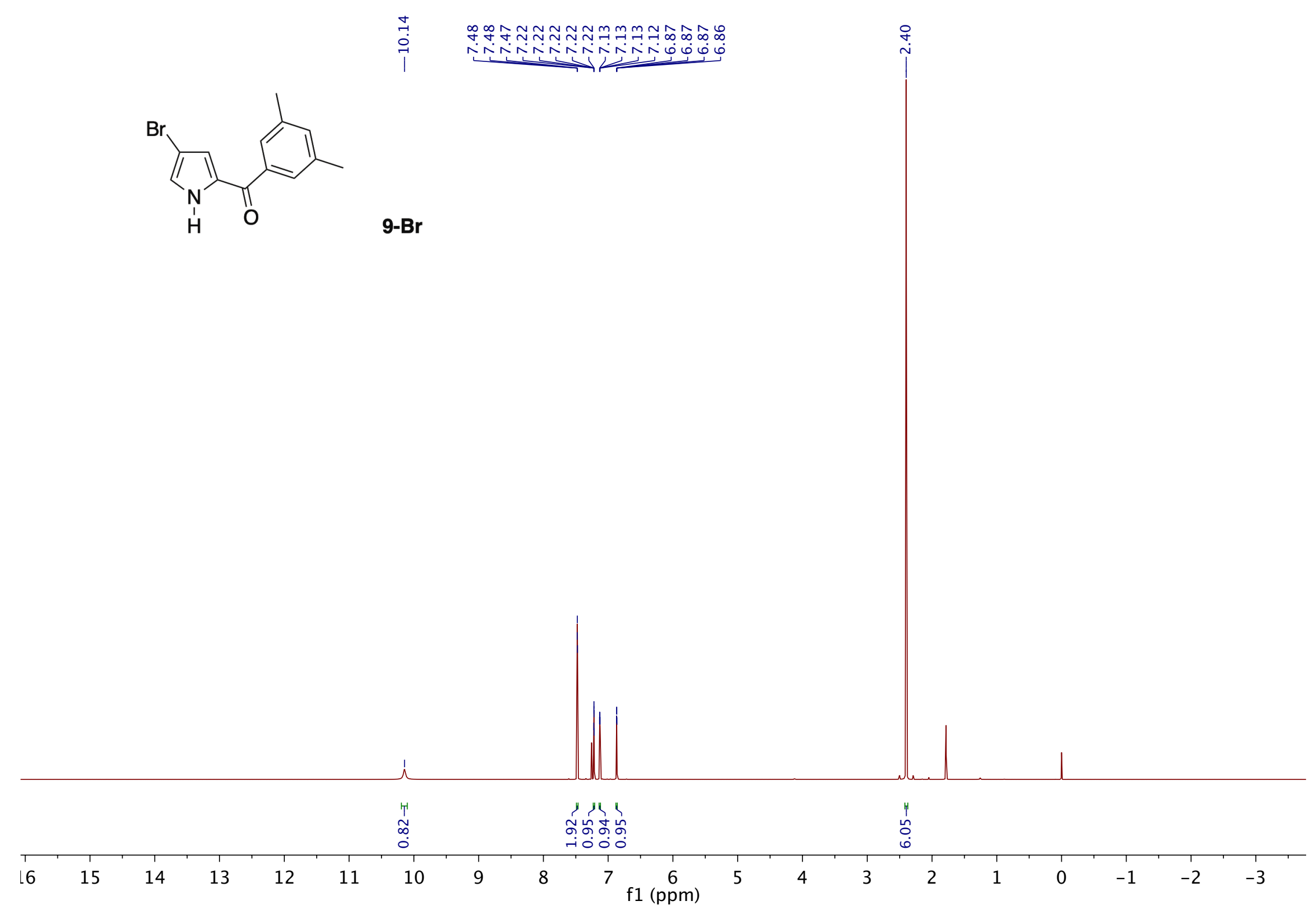




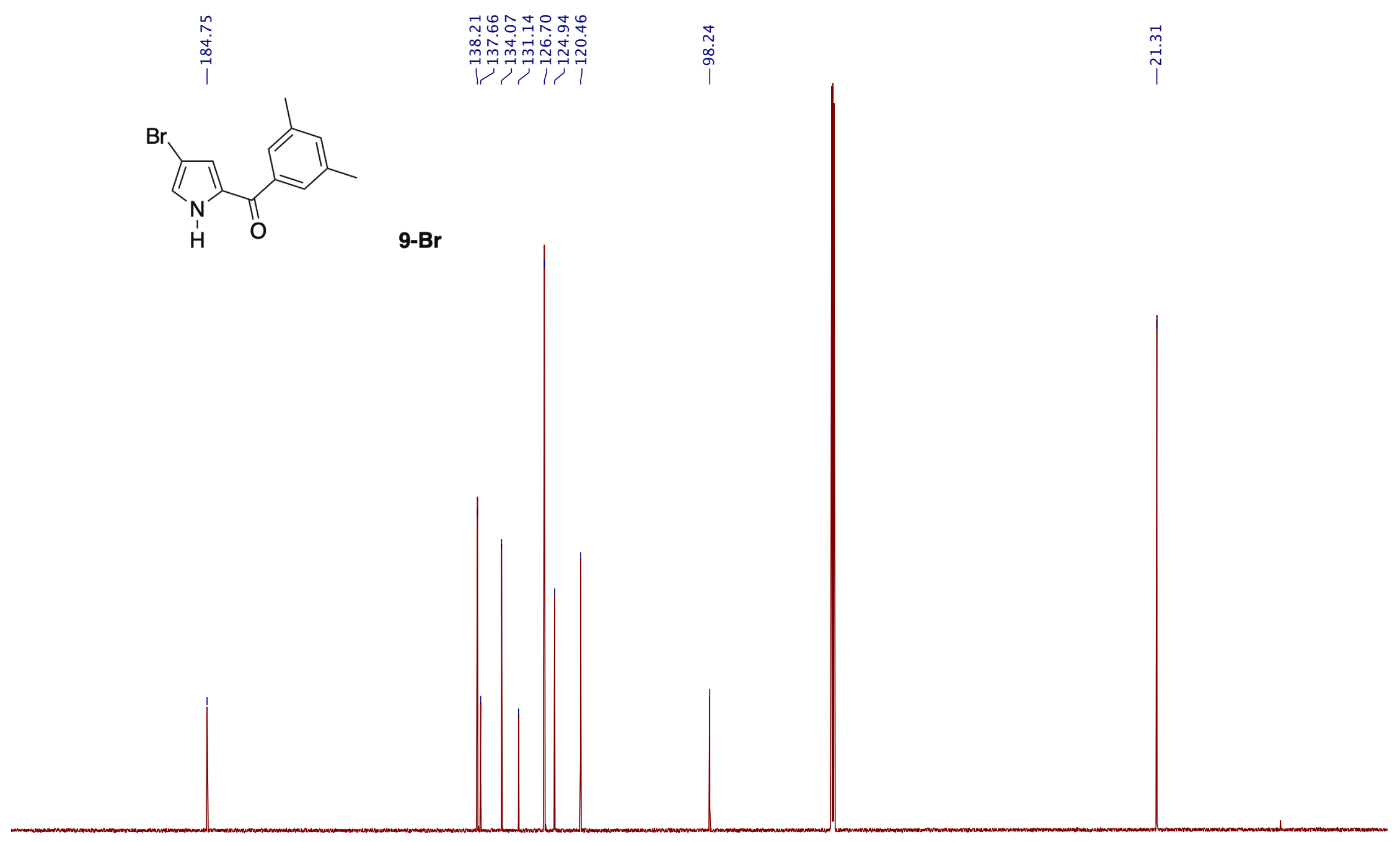

$\begin{array}{lllllllllllllllllllllll}210 & 200 & 190 & 180 & 170 & 160 & 150 & 140 & 130 & 120 & 110 & \begin{array}{l}100 \\ \mathrm{f} 1(\mathrm{ppm})\end{array} & 90 & 80 & 70 & 60 & 50 & 40 & 30 & 20 & 10 & 0 & -10\end{array}$ 


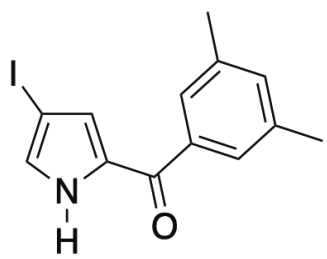

9-I

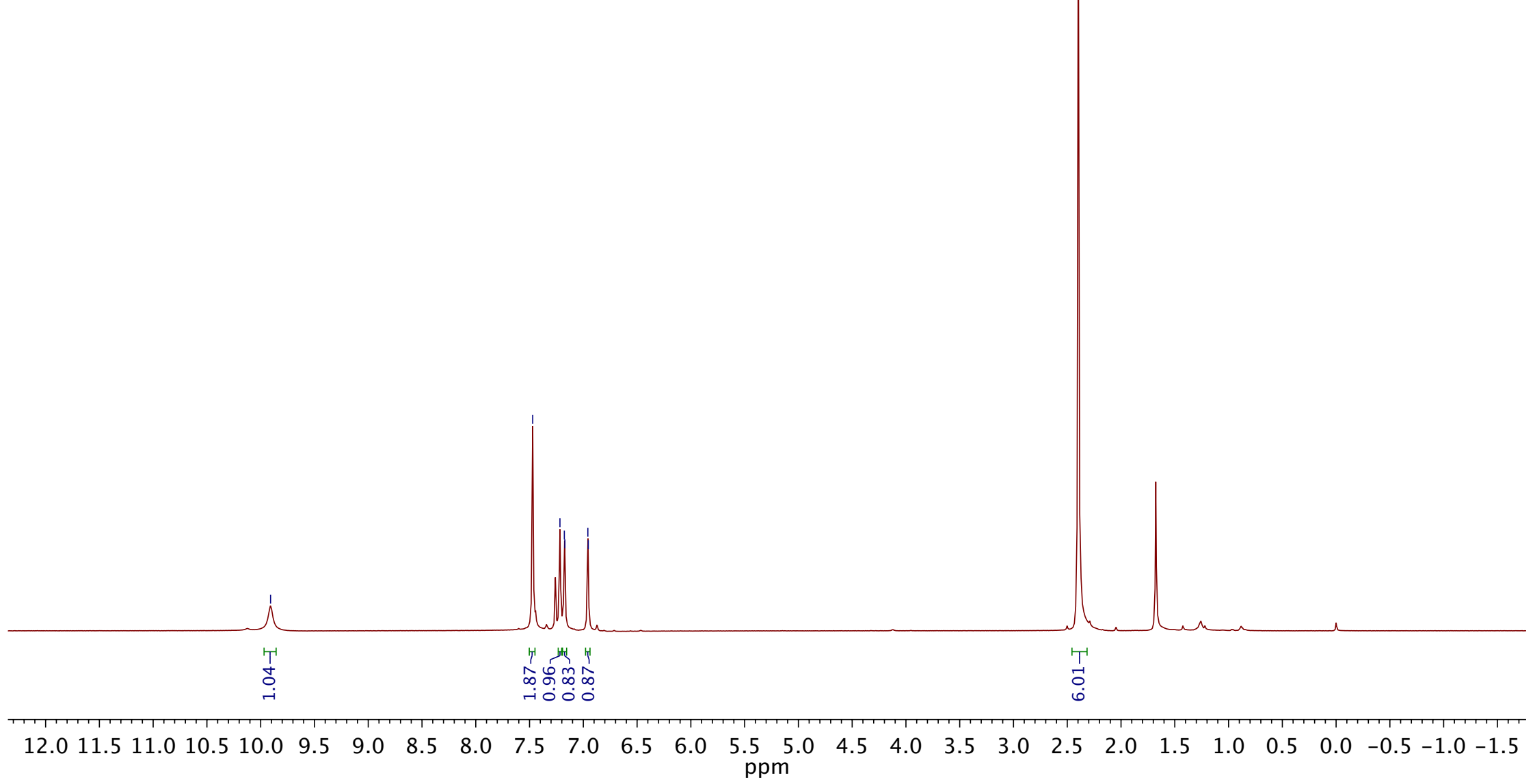



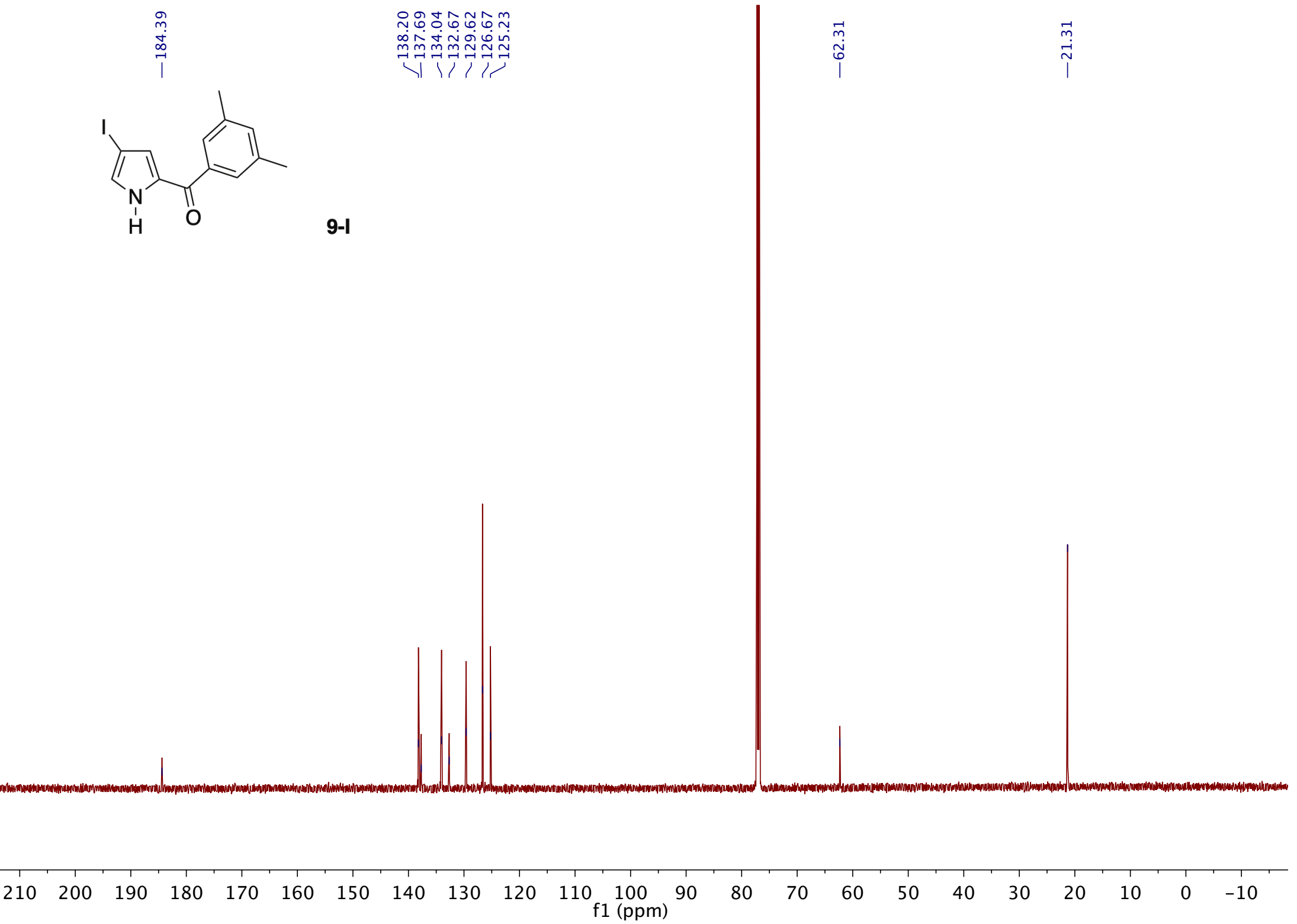


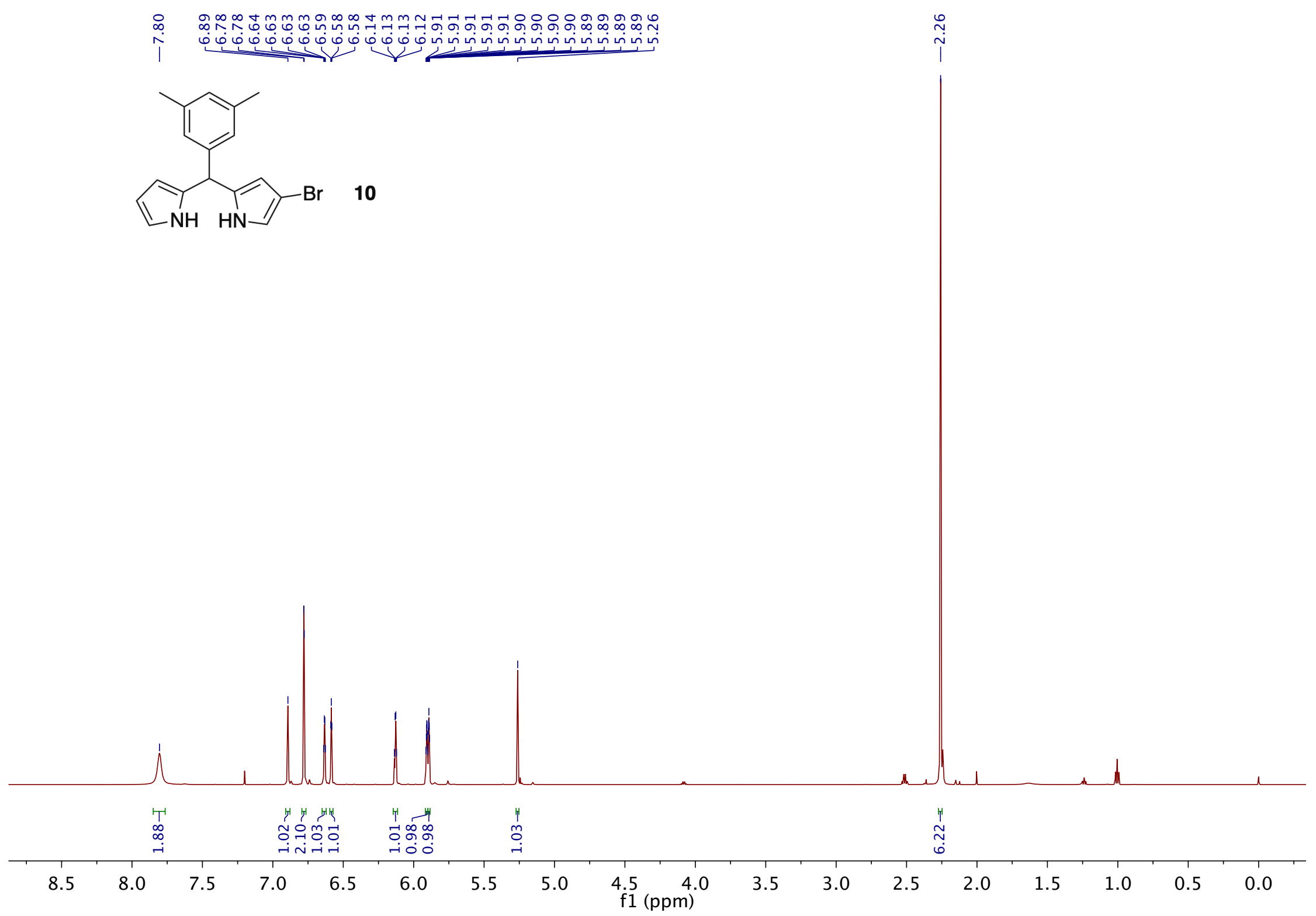



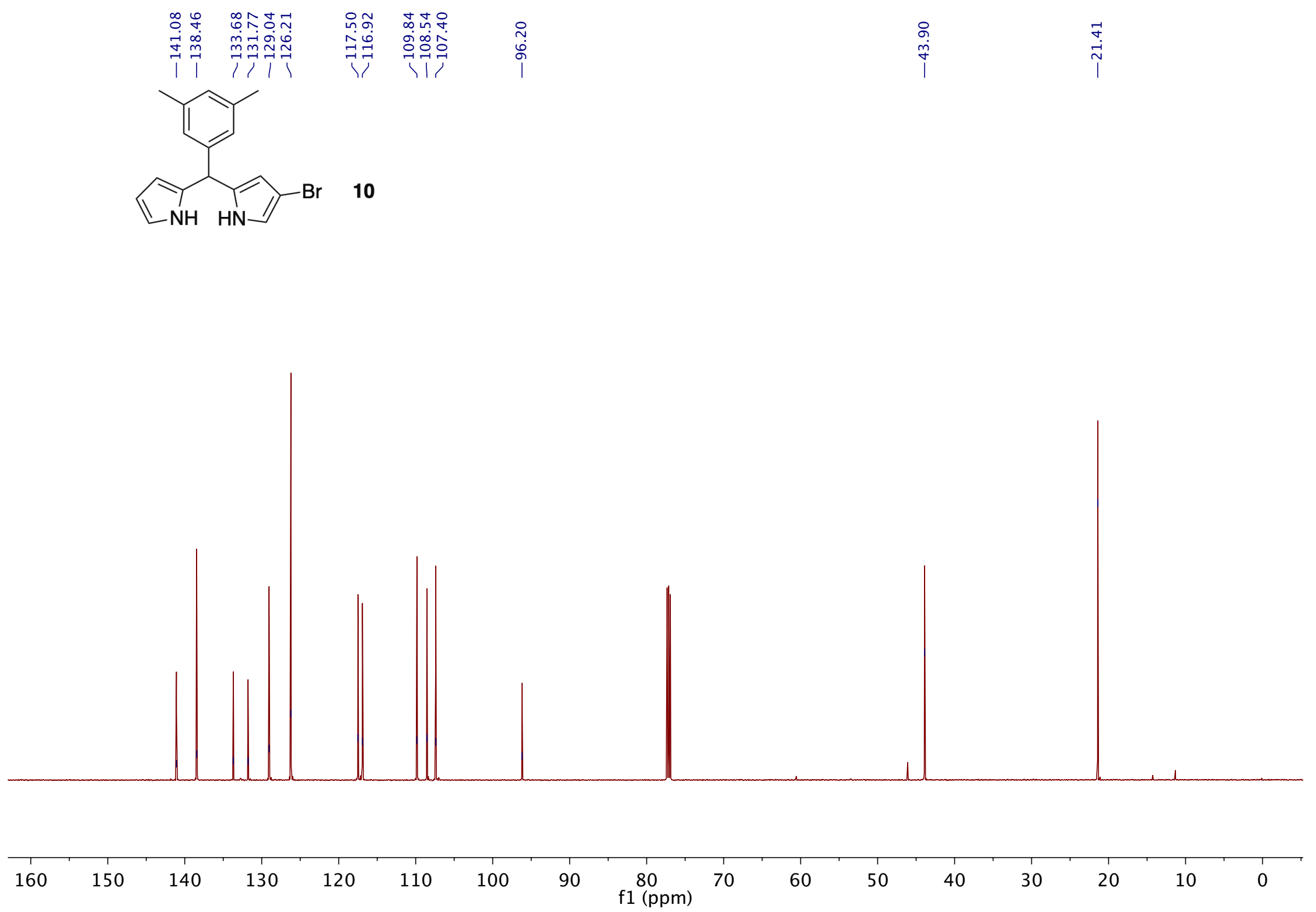


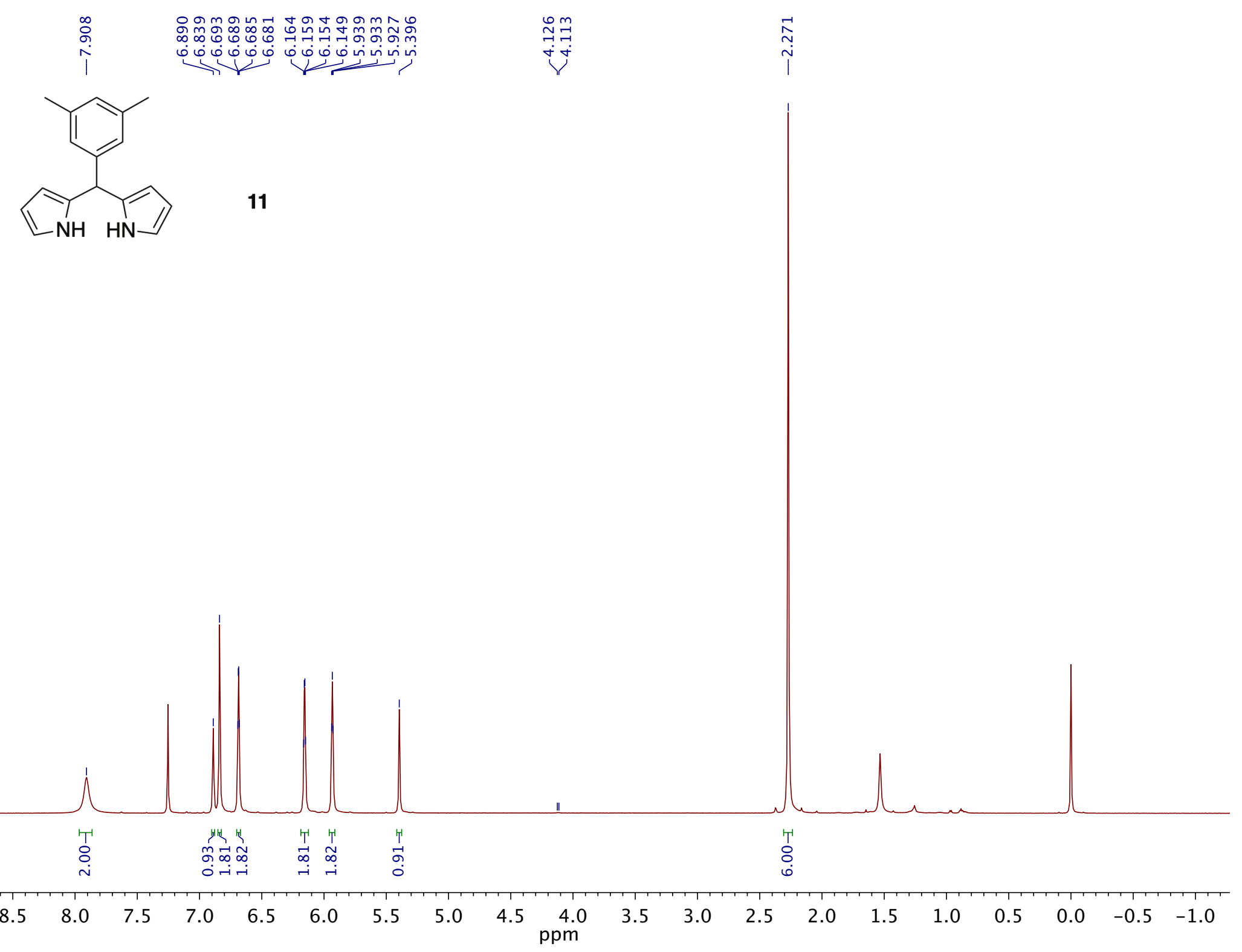




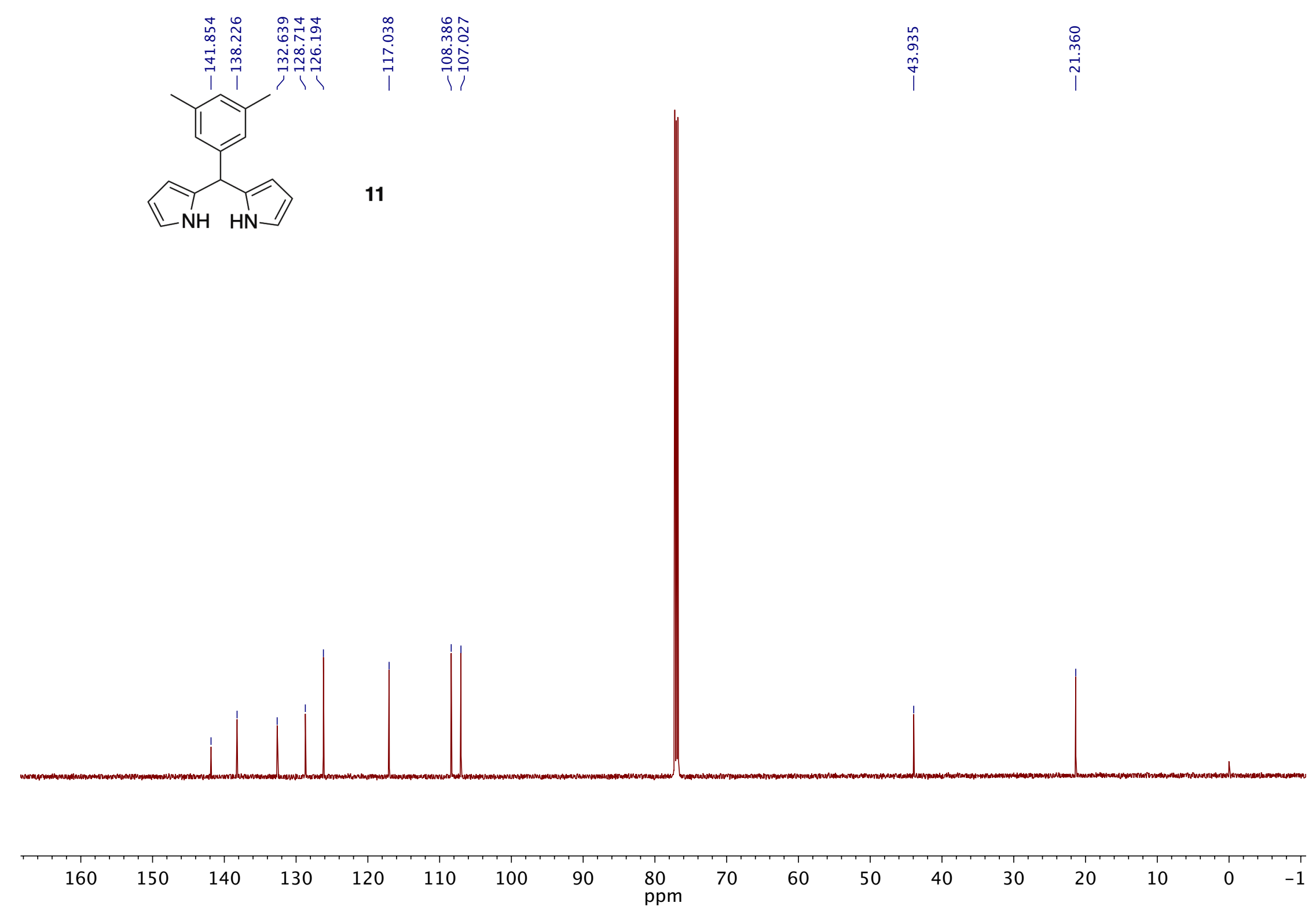




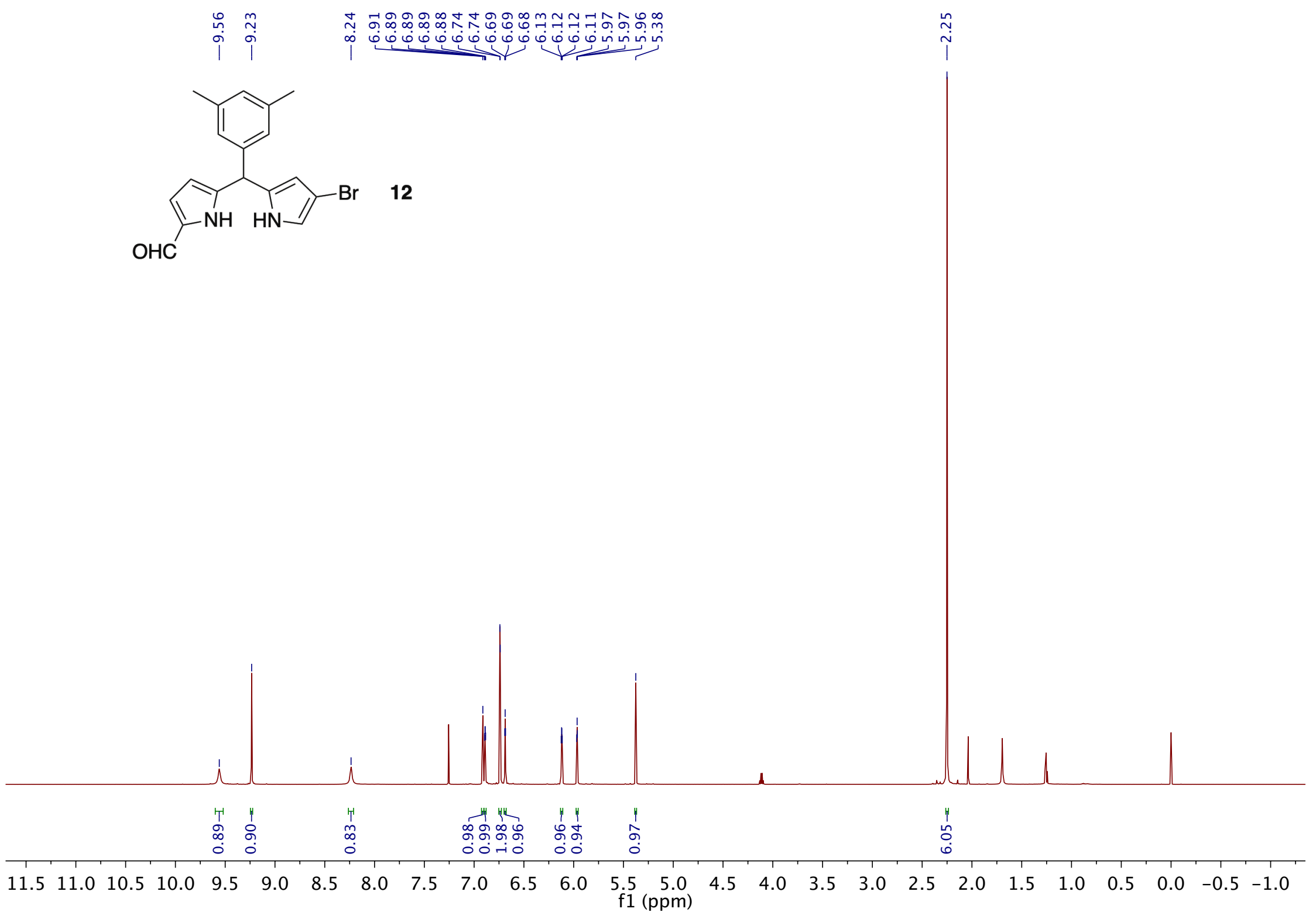




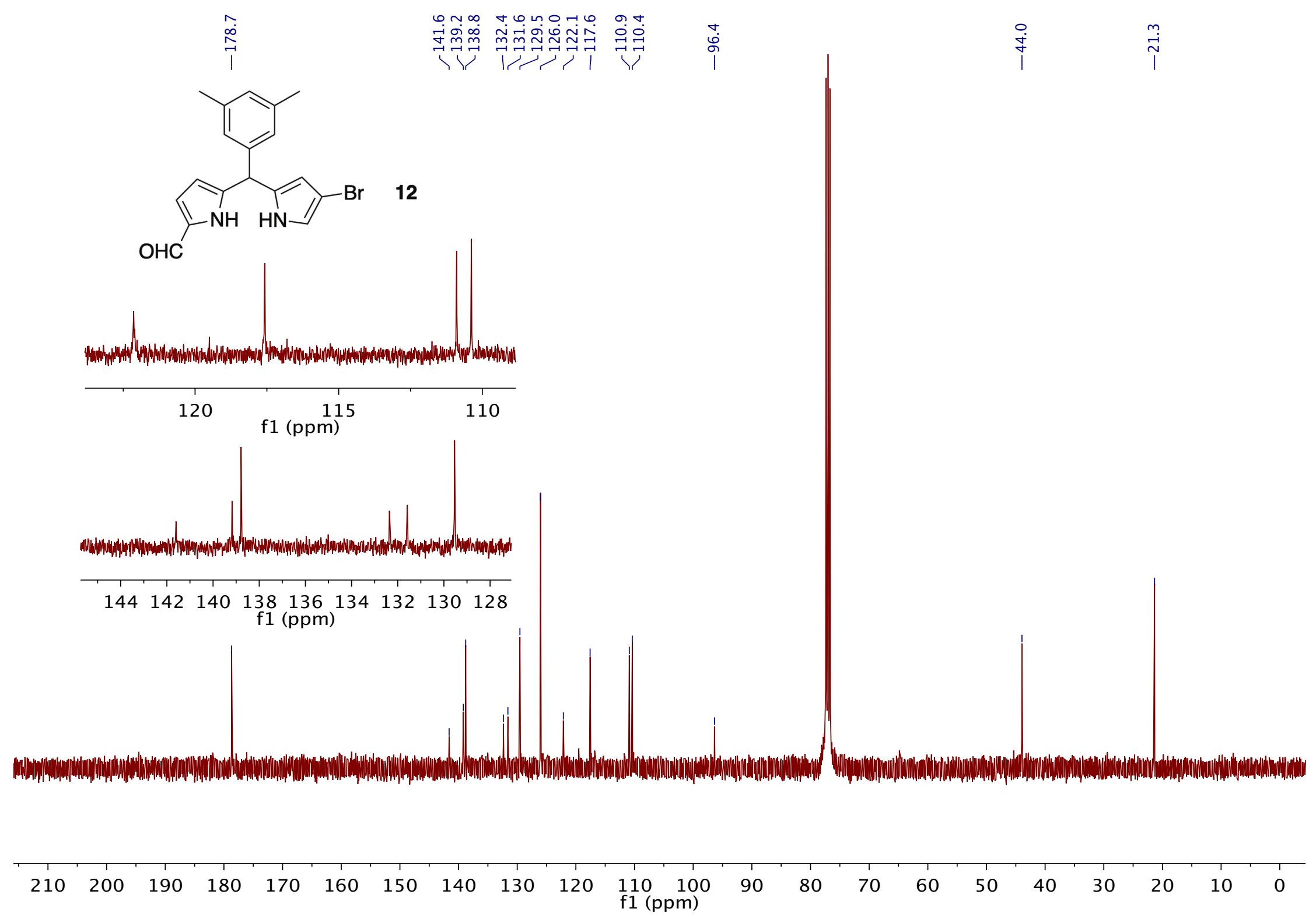




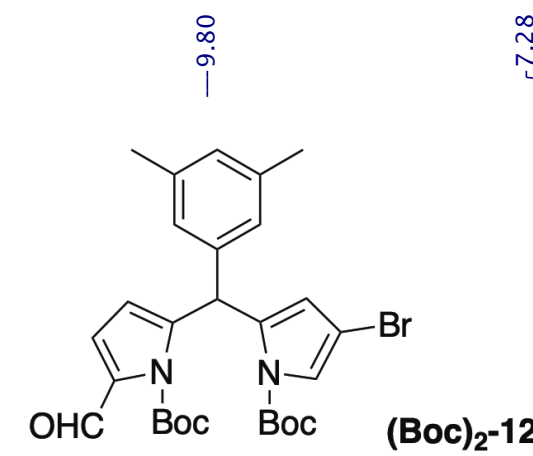

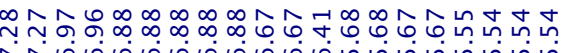

人

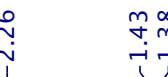

$\mathrm{OHC}$ Boc Boc $(\mathrm{Boc})_{2}-12$

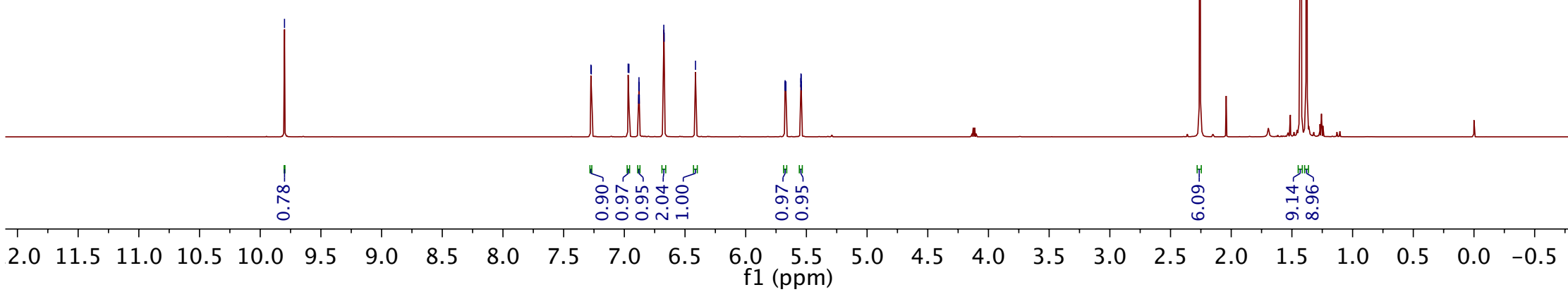



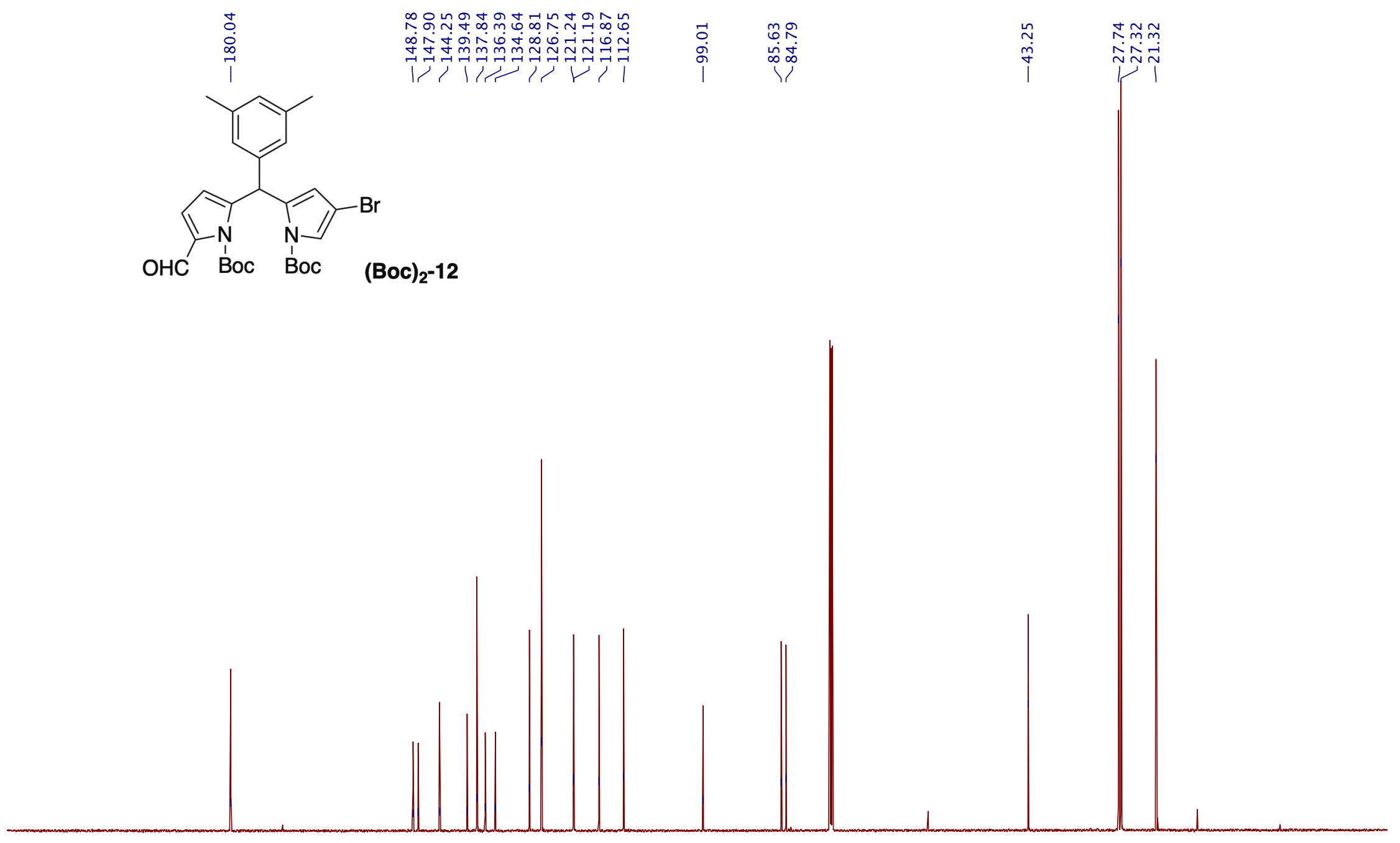

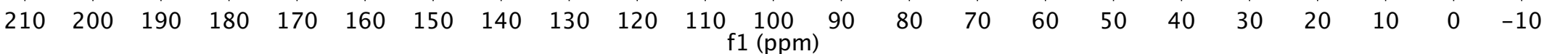



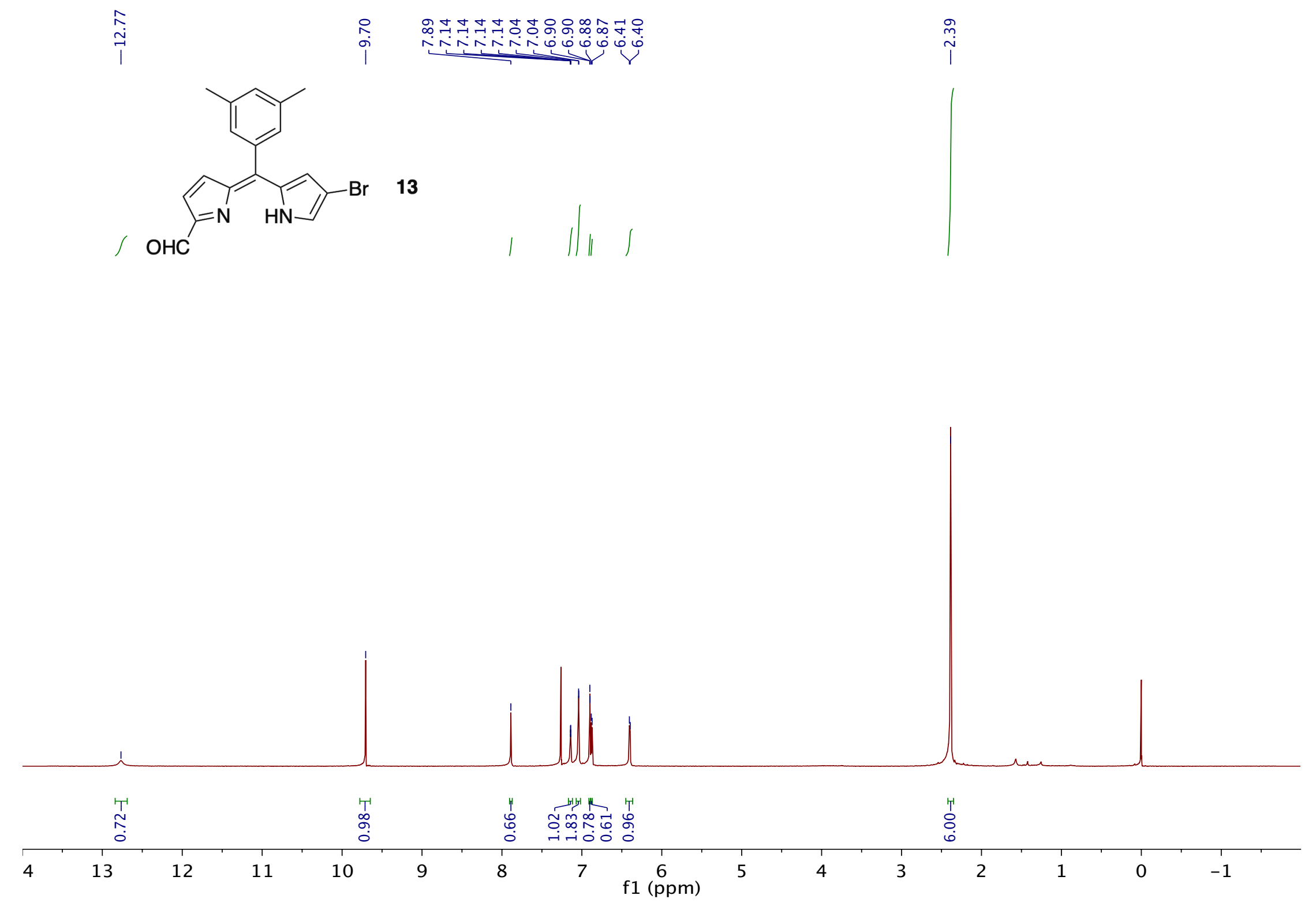


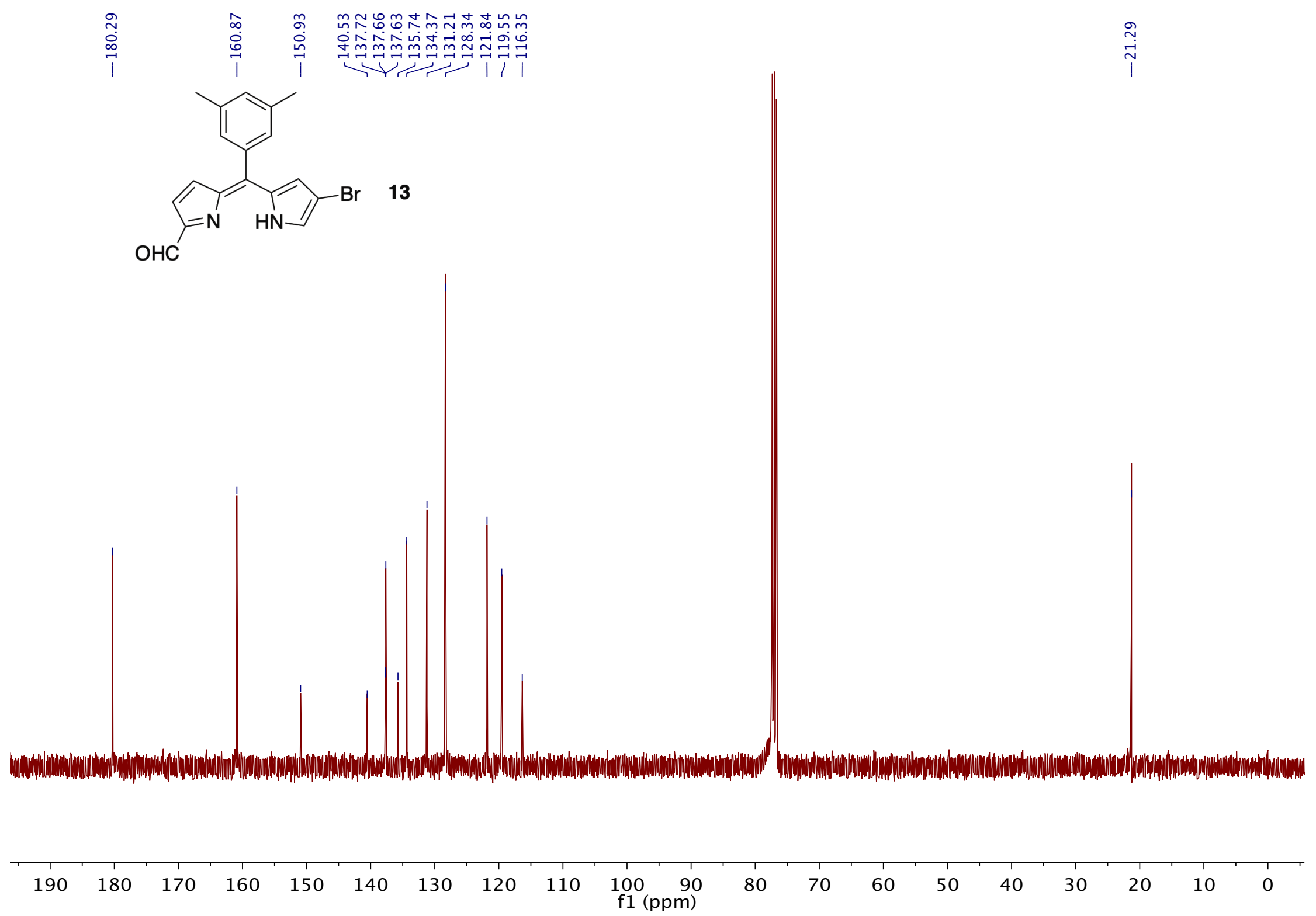




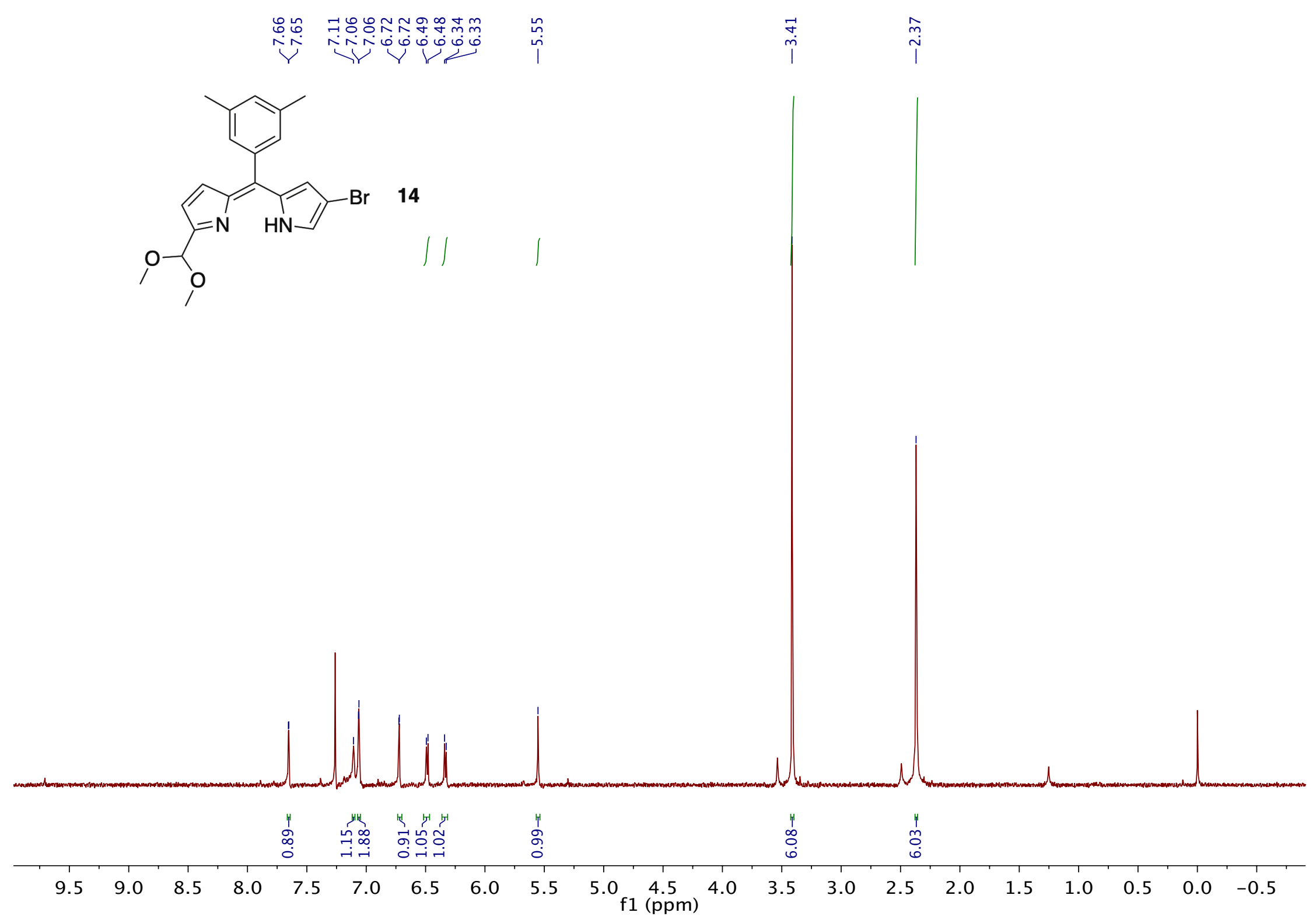




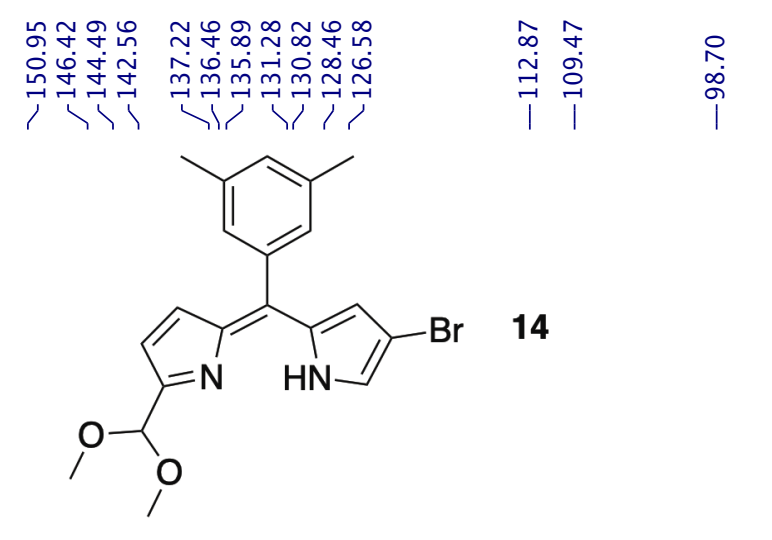

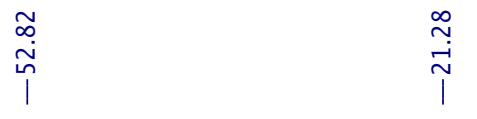

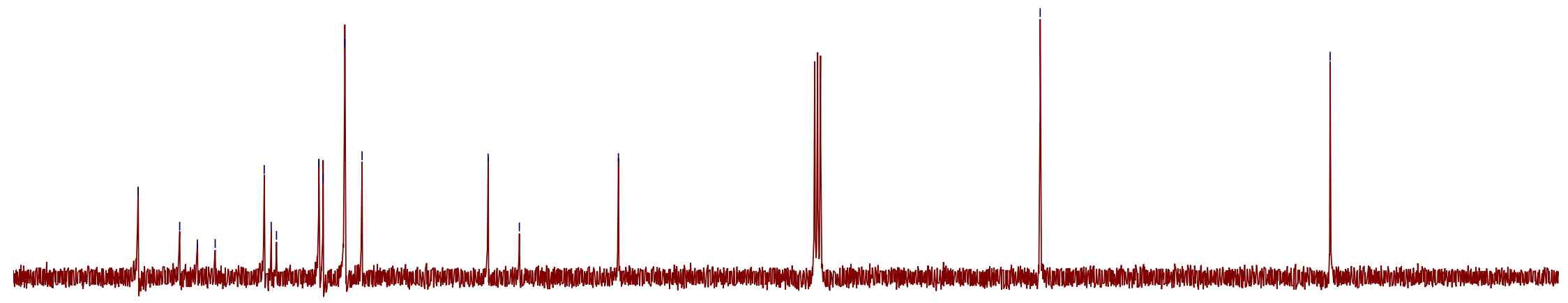

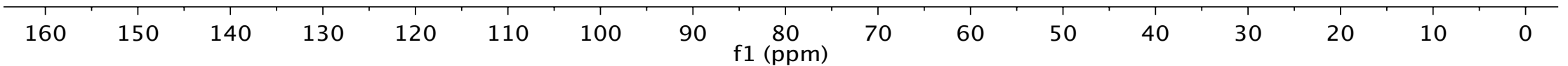



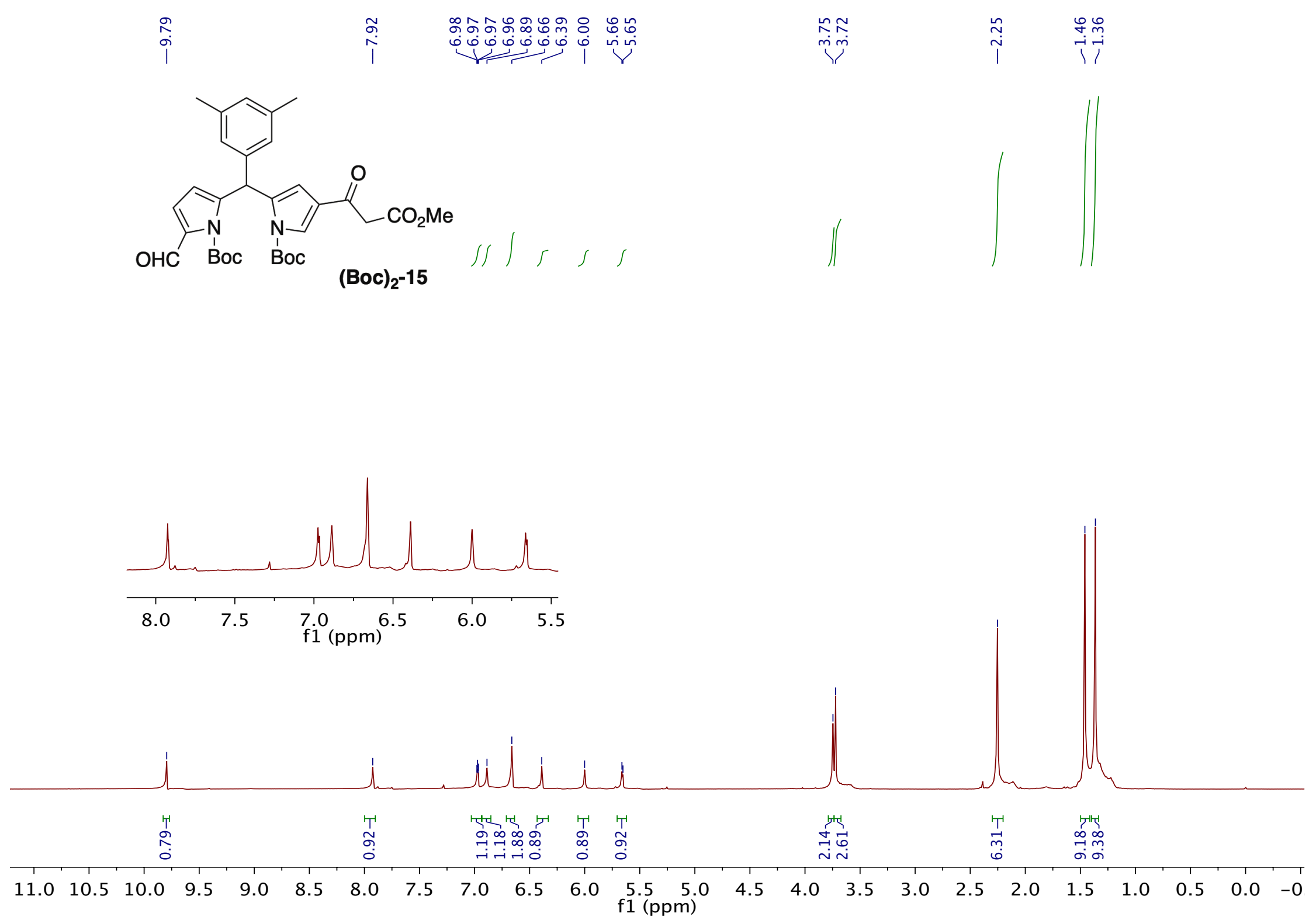

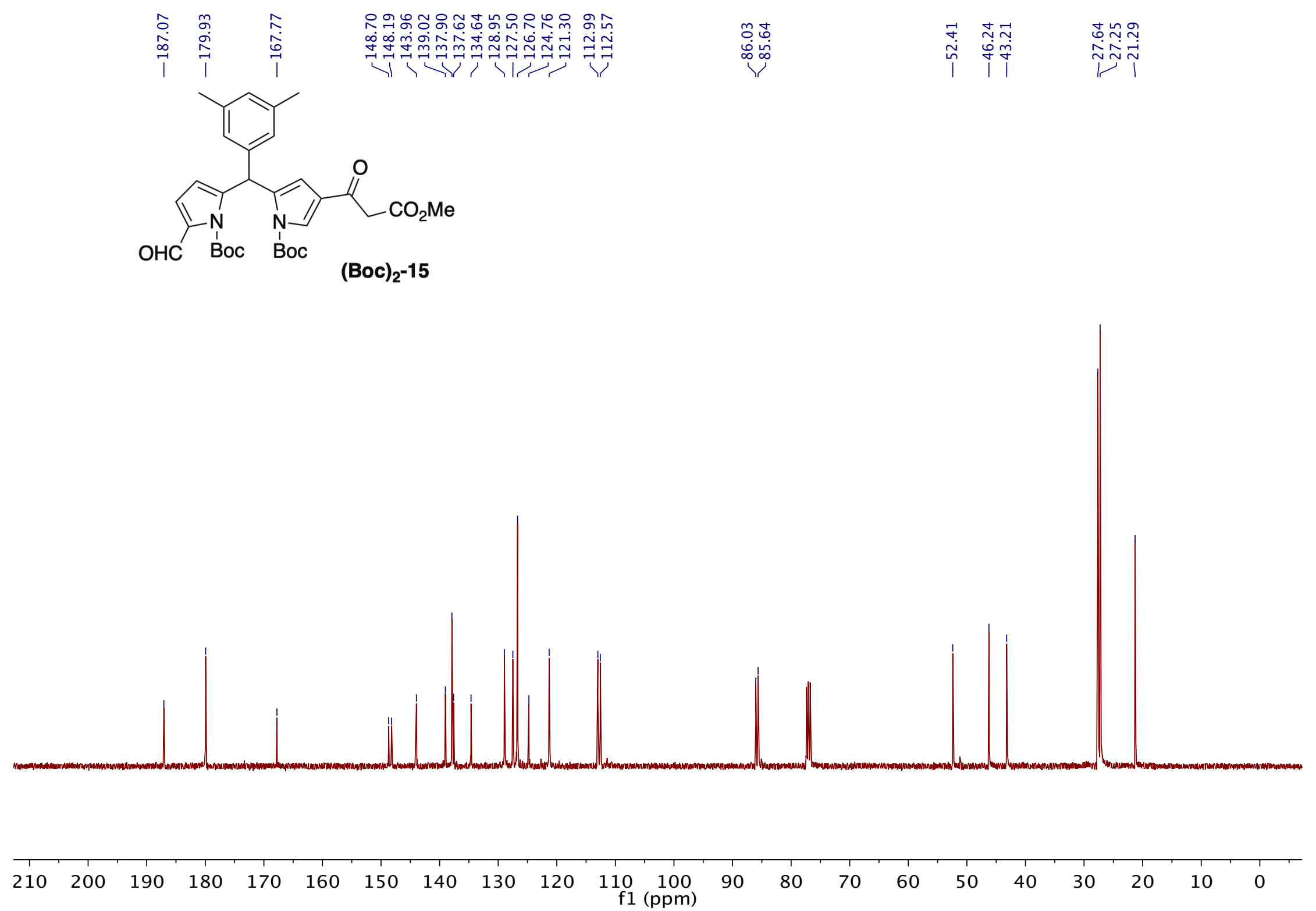

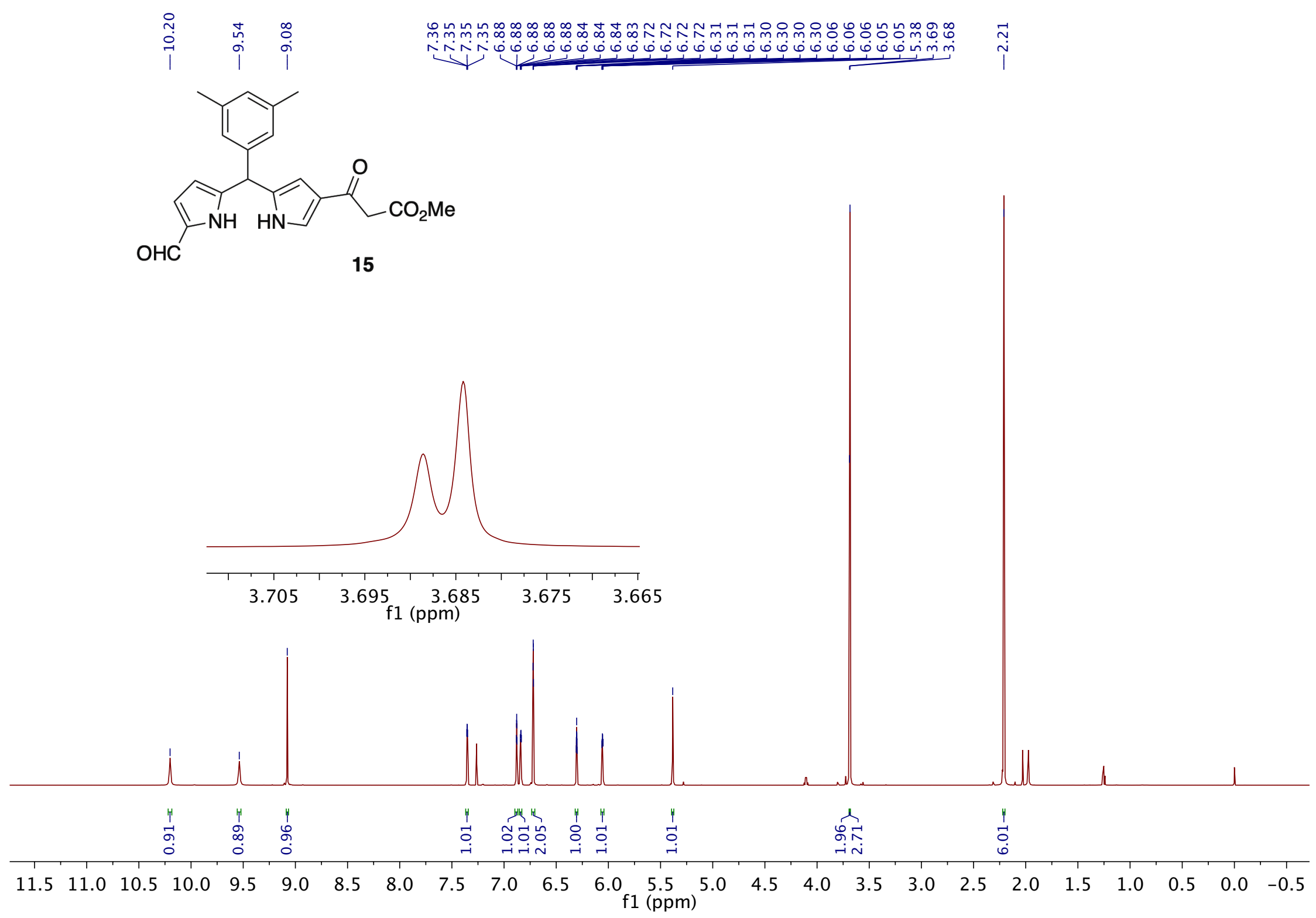

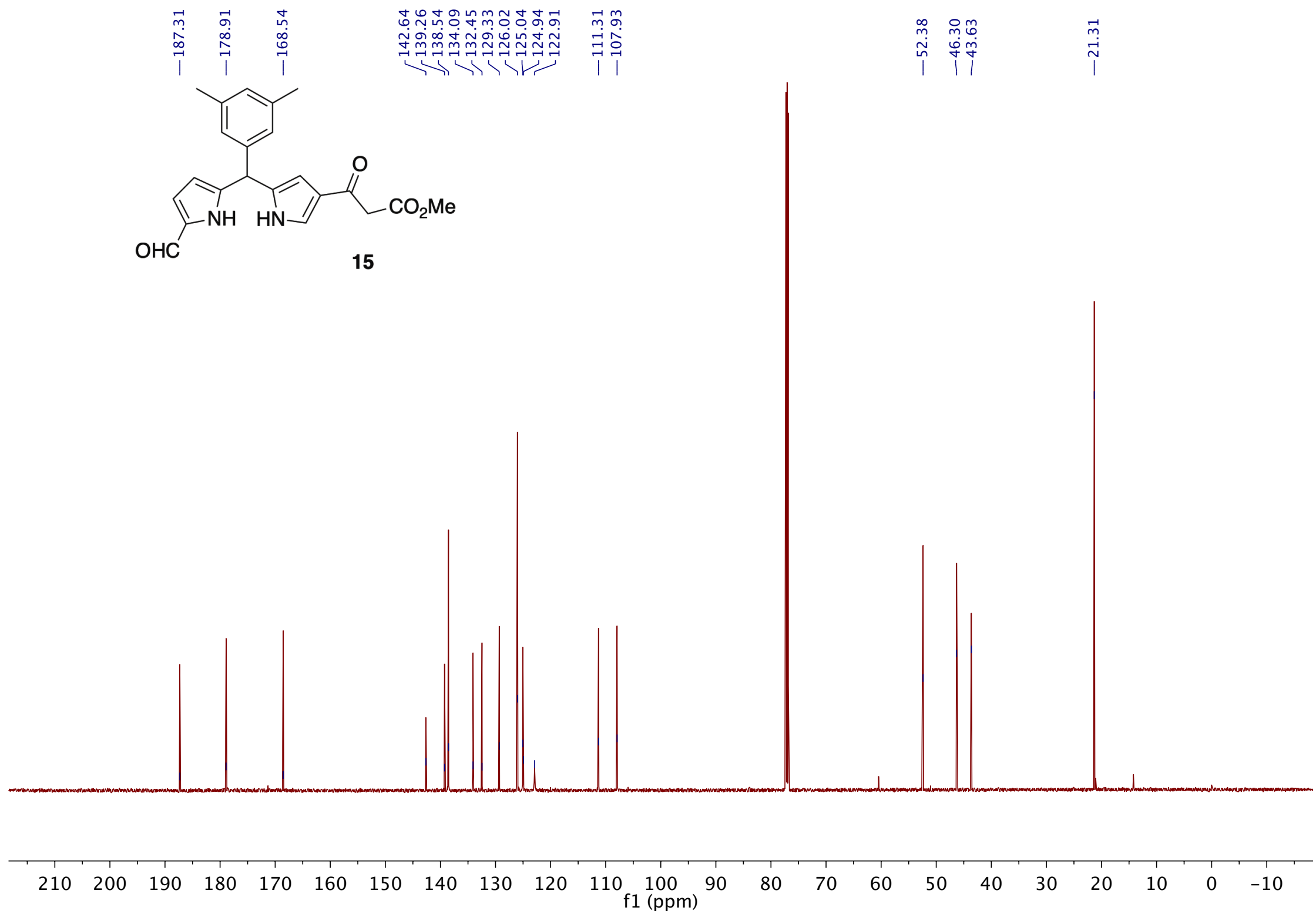

S64 


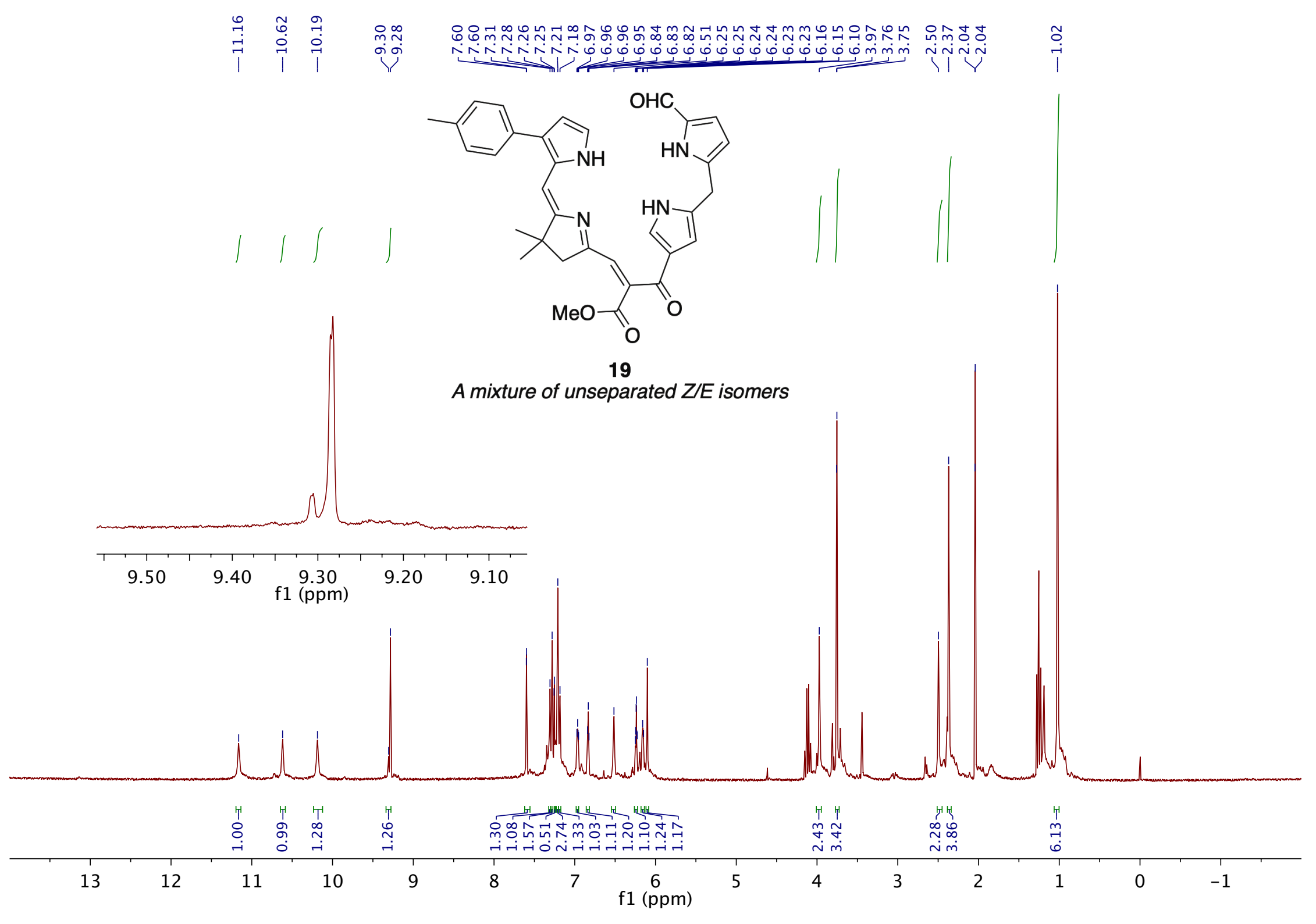




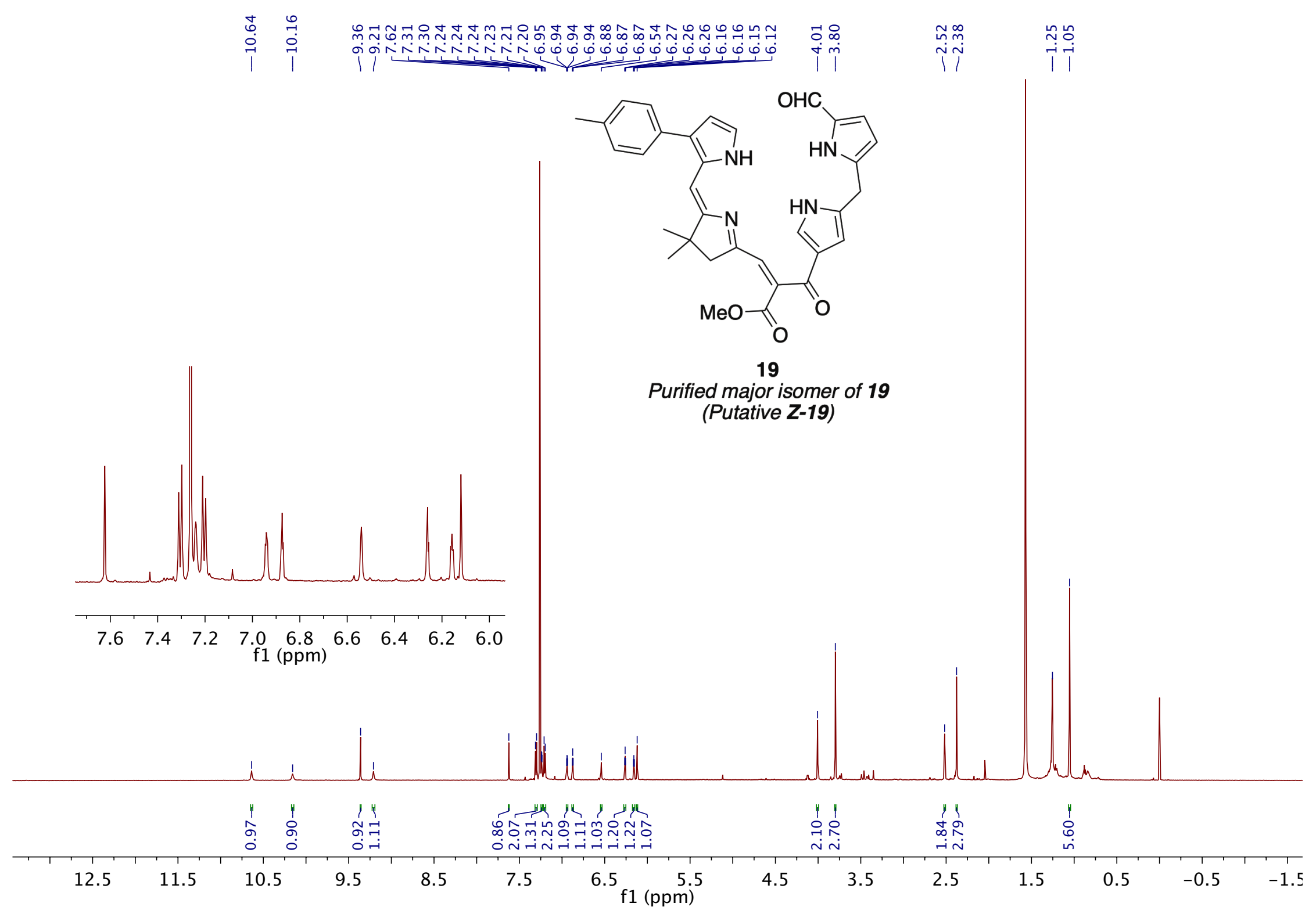




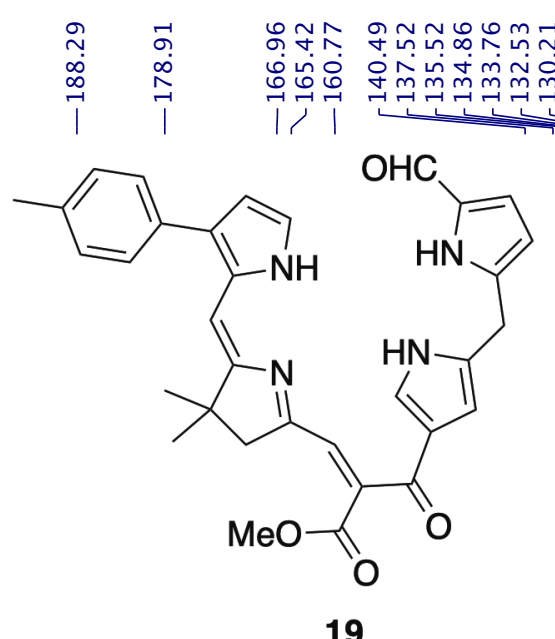

Purified major isomer of 19

(Putative Z-19)
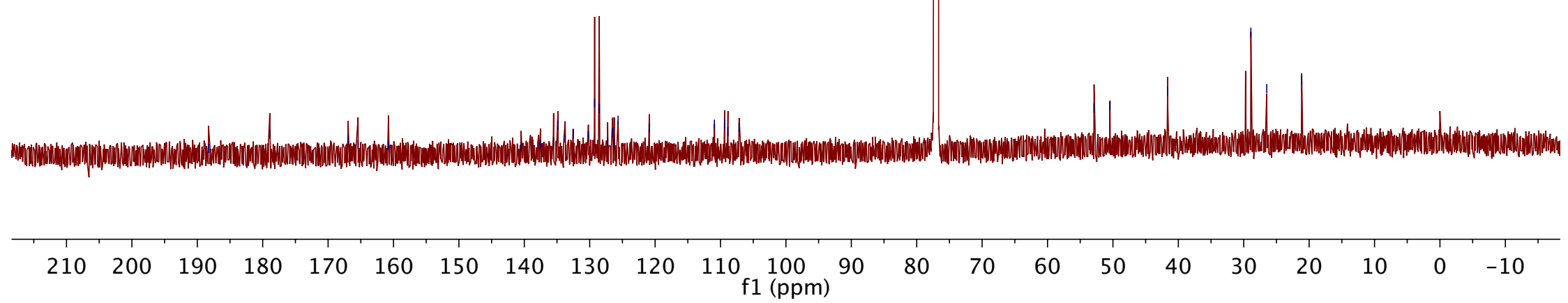


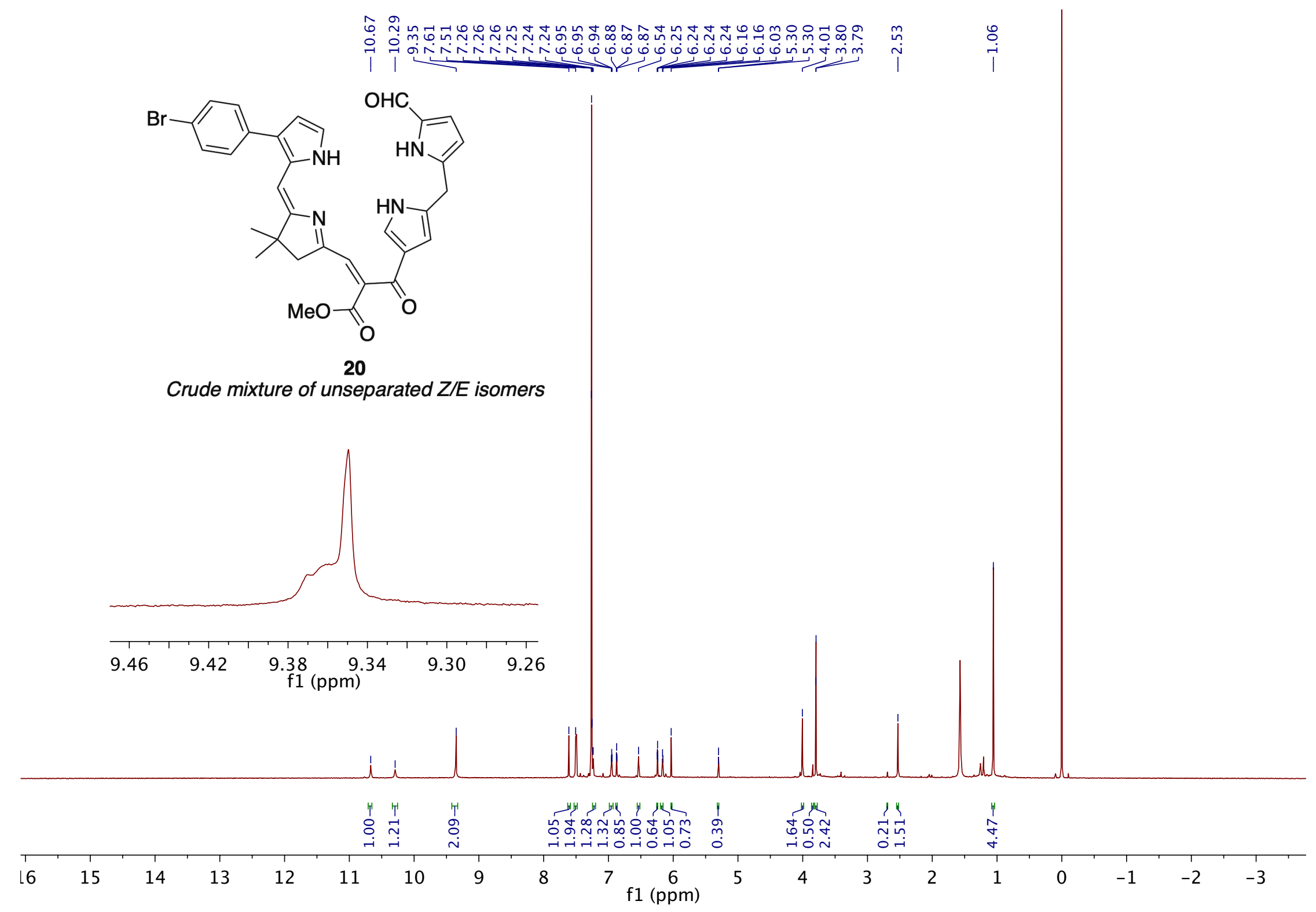




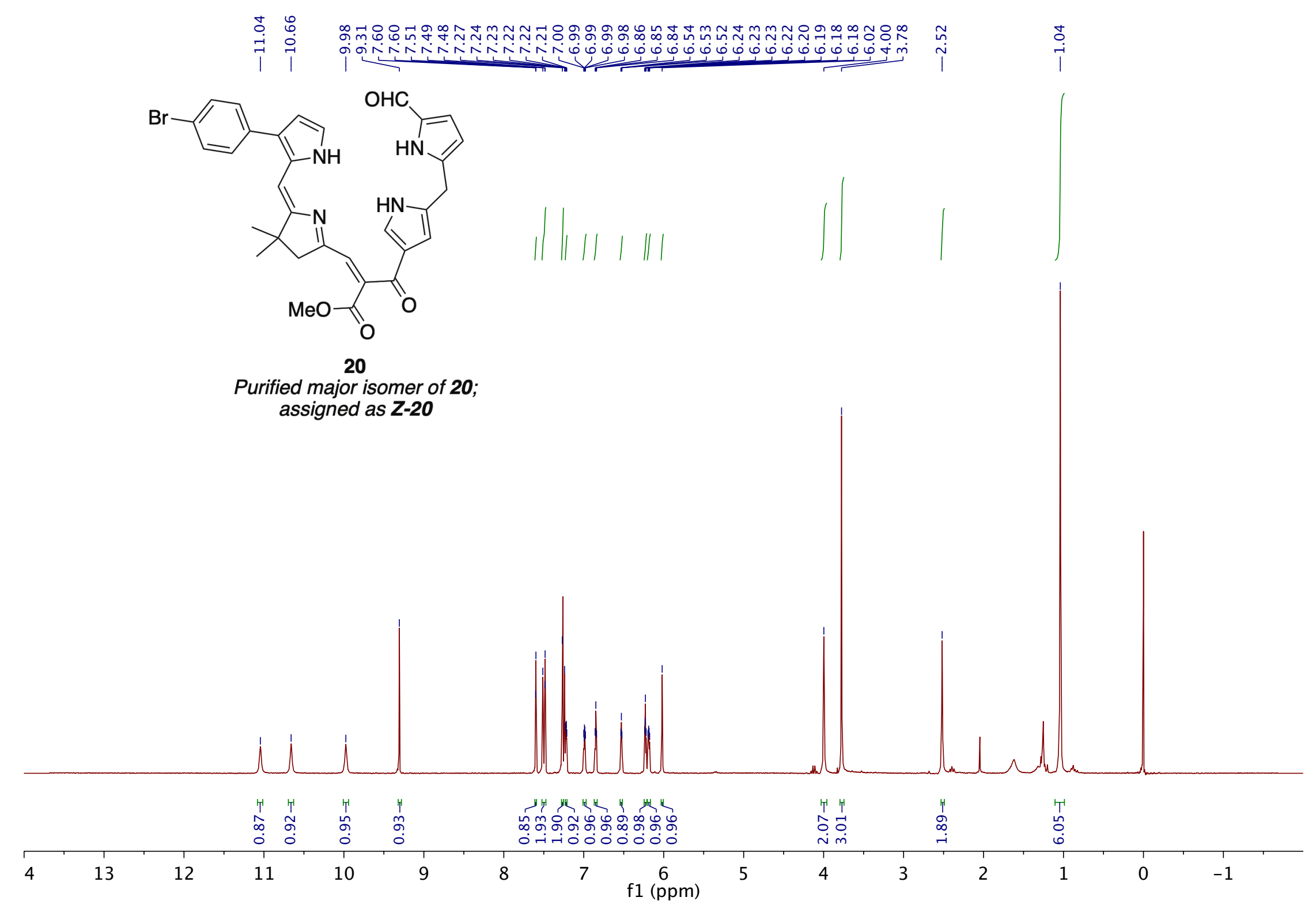




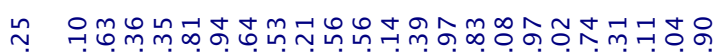

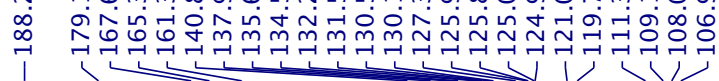

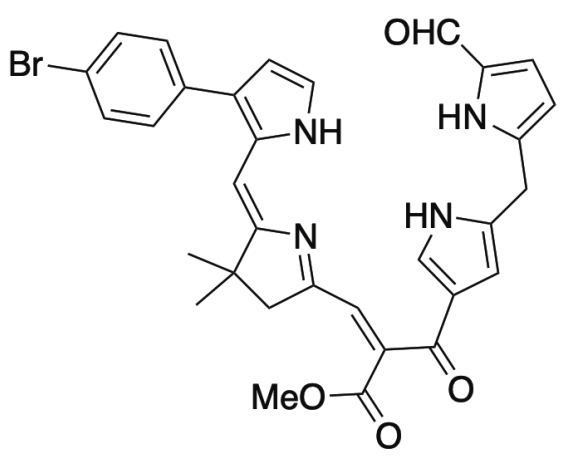

20

Purified major isomer of 20

assigned as Z-20

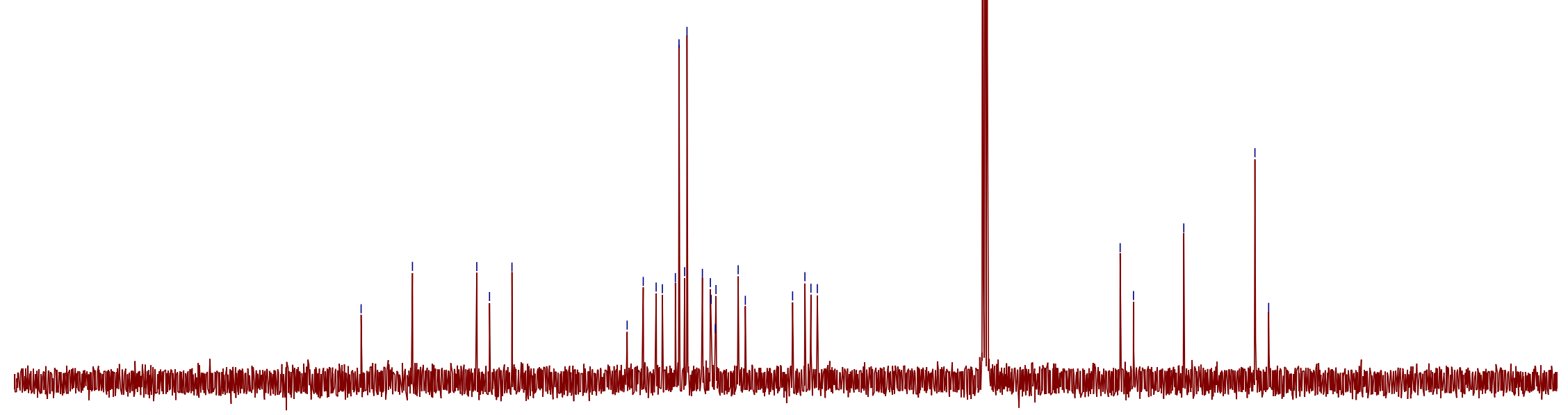

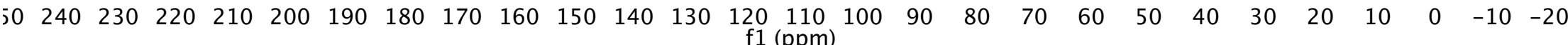




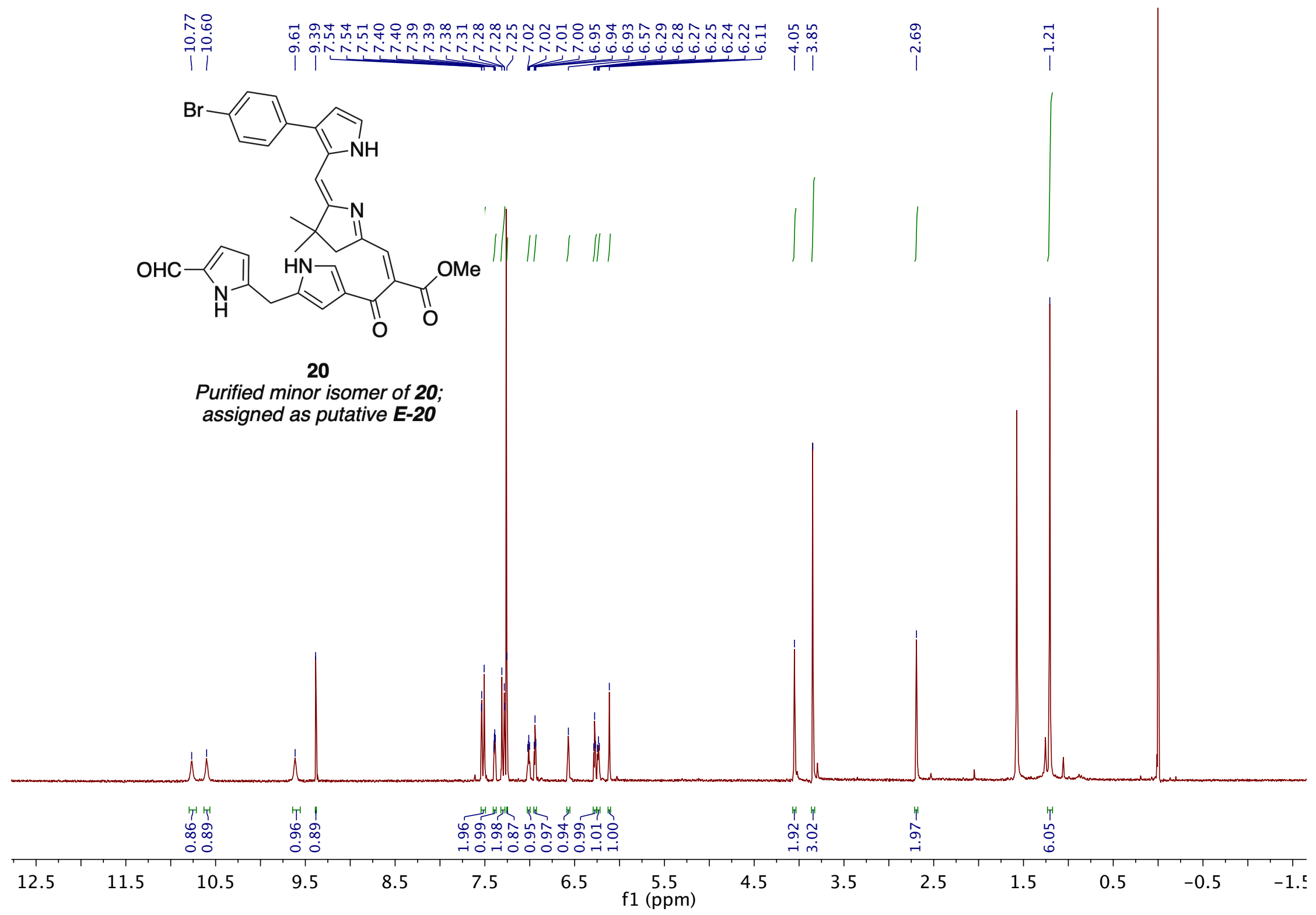

S71 


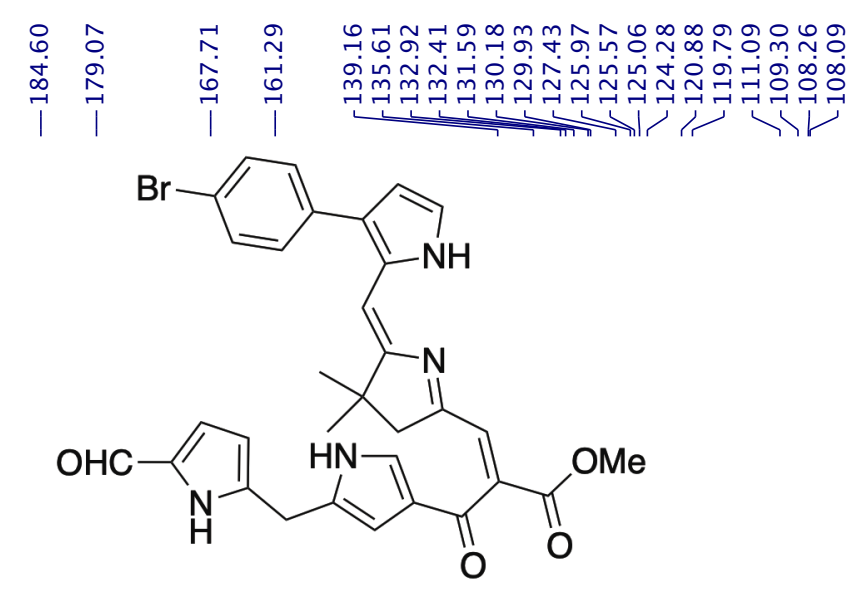

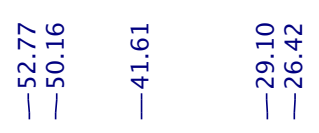

20

Purified minor isomer of 20; assigned as putative E-20

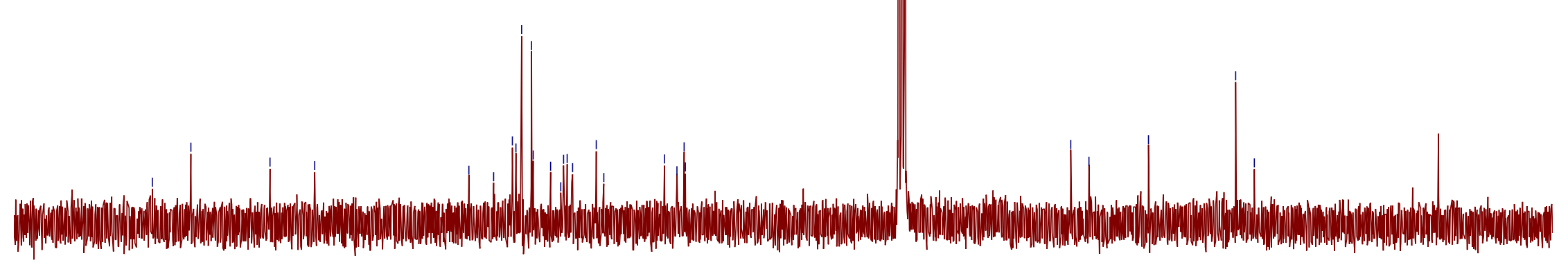

$\begin{array}{rllllllllllllllllllll}200 & 190 & 180 & 170 & 160 & 150 & 140 & 130 & 120 & 110 & \begin{array}{r}100 \\ \mathrm{f} 1(\mathrm{ppm})\end{array} & 80 & 70 & 60 & 50 & 40 & 30 & 20 & 10 & 0 & -10\end{array}$ 


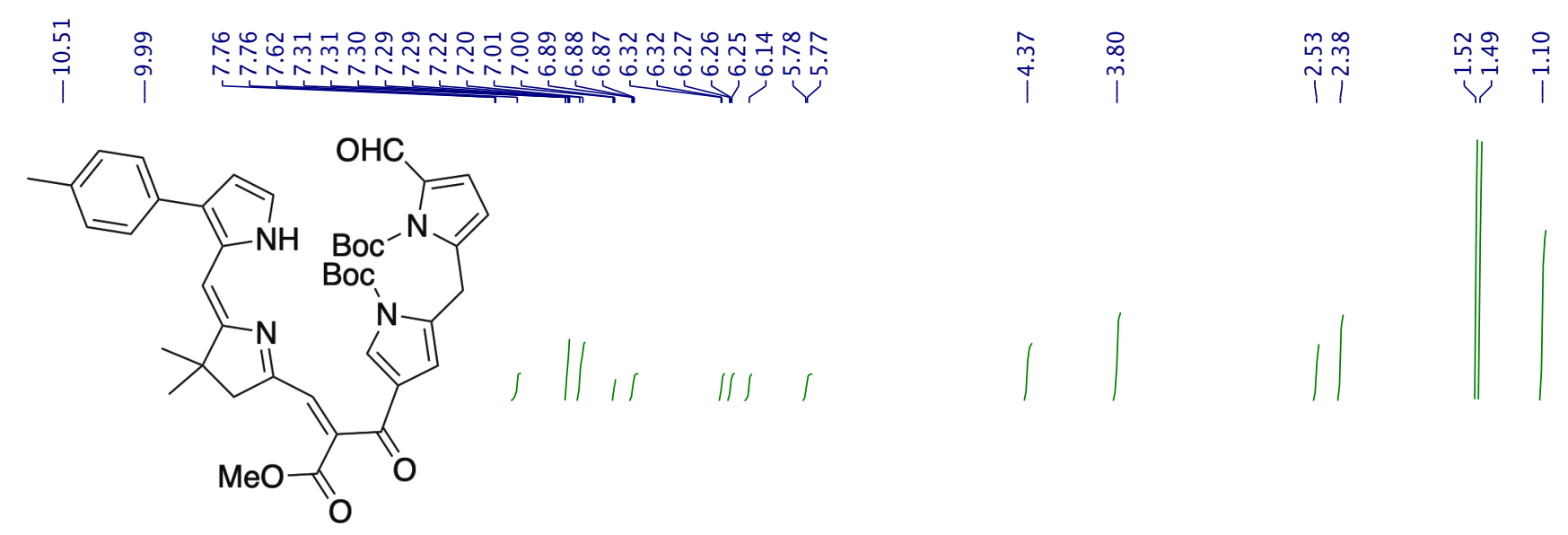

$(\mathrm{Boc})_{2}-19$

(Putative Z-configuration)

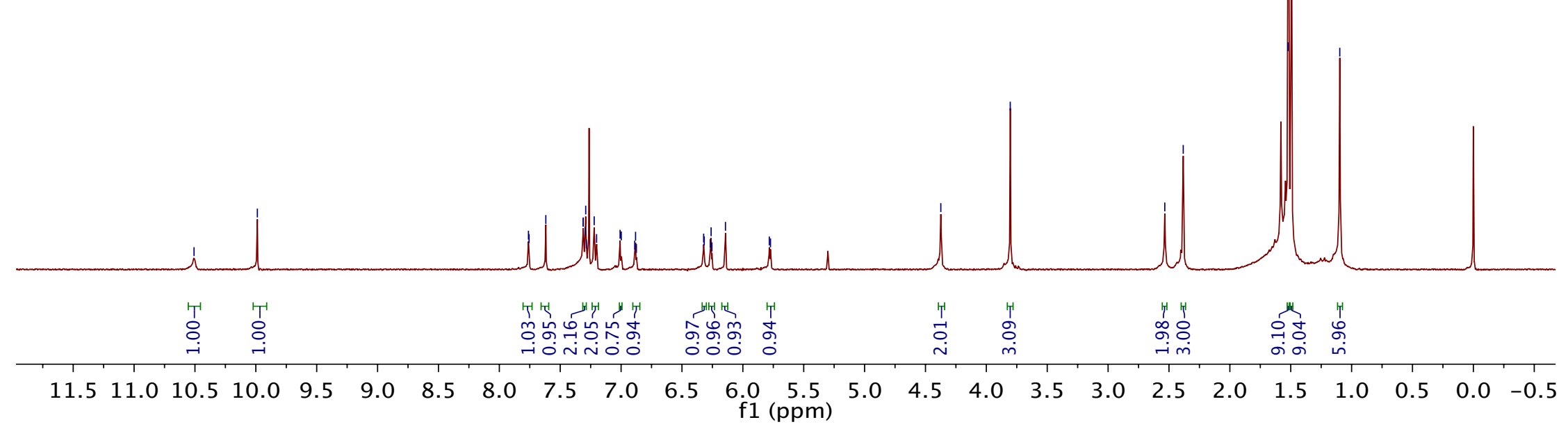



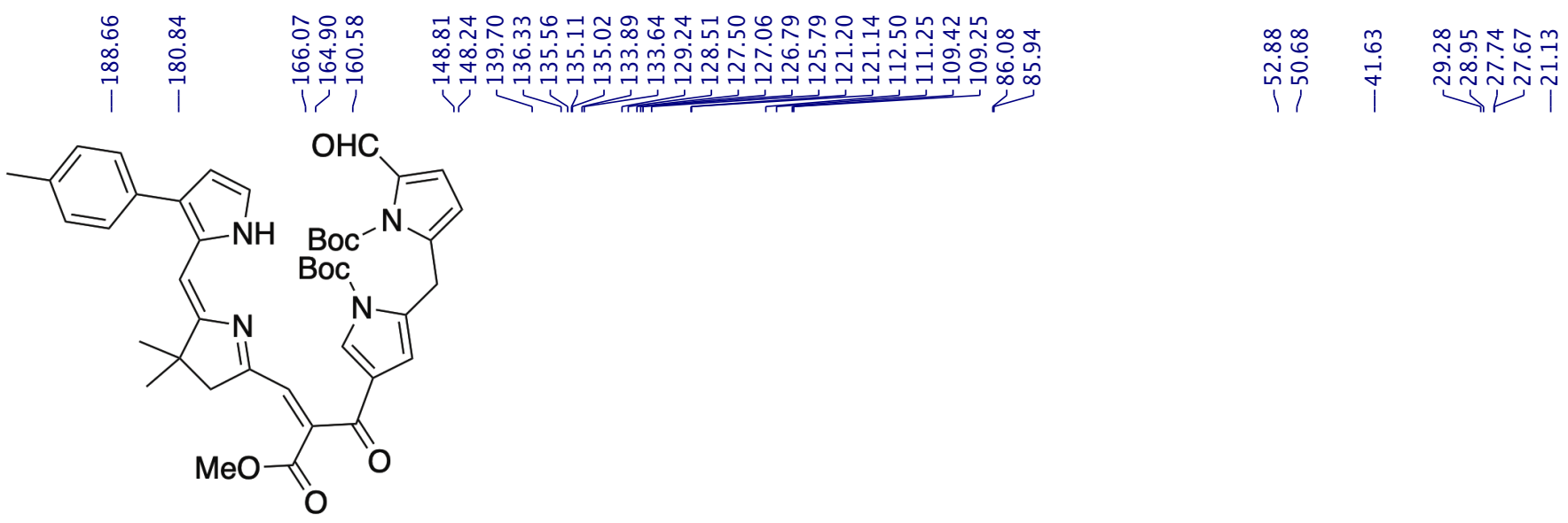

(Boc) $)_{2}-19$

(Putative Z-configuration)

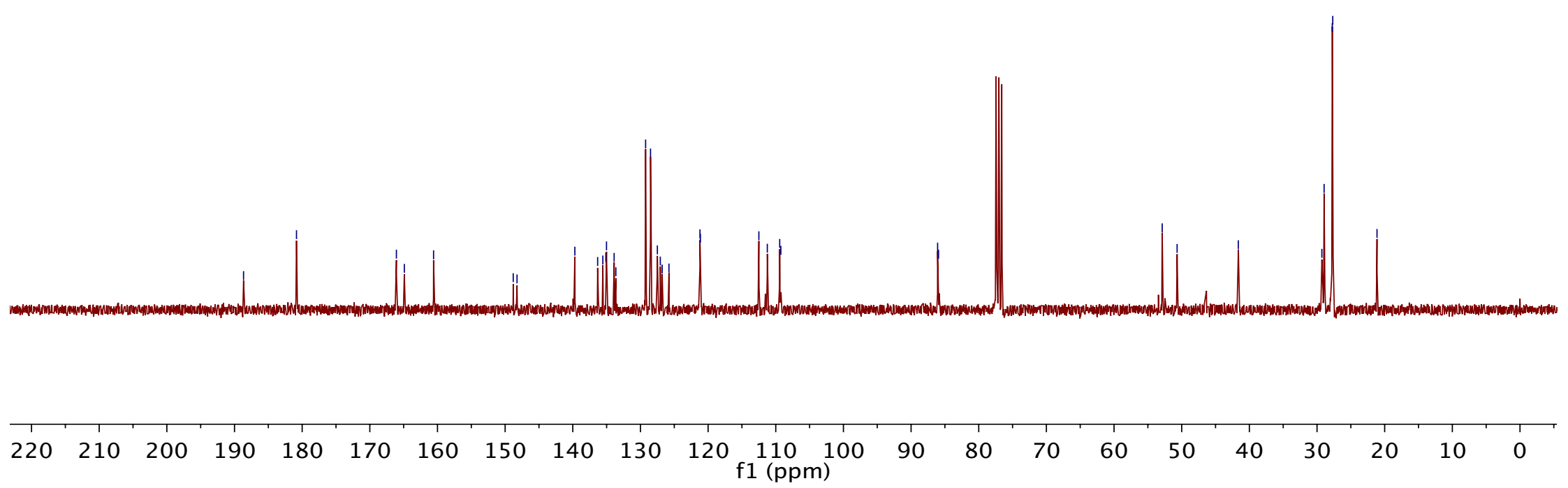



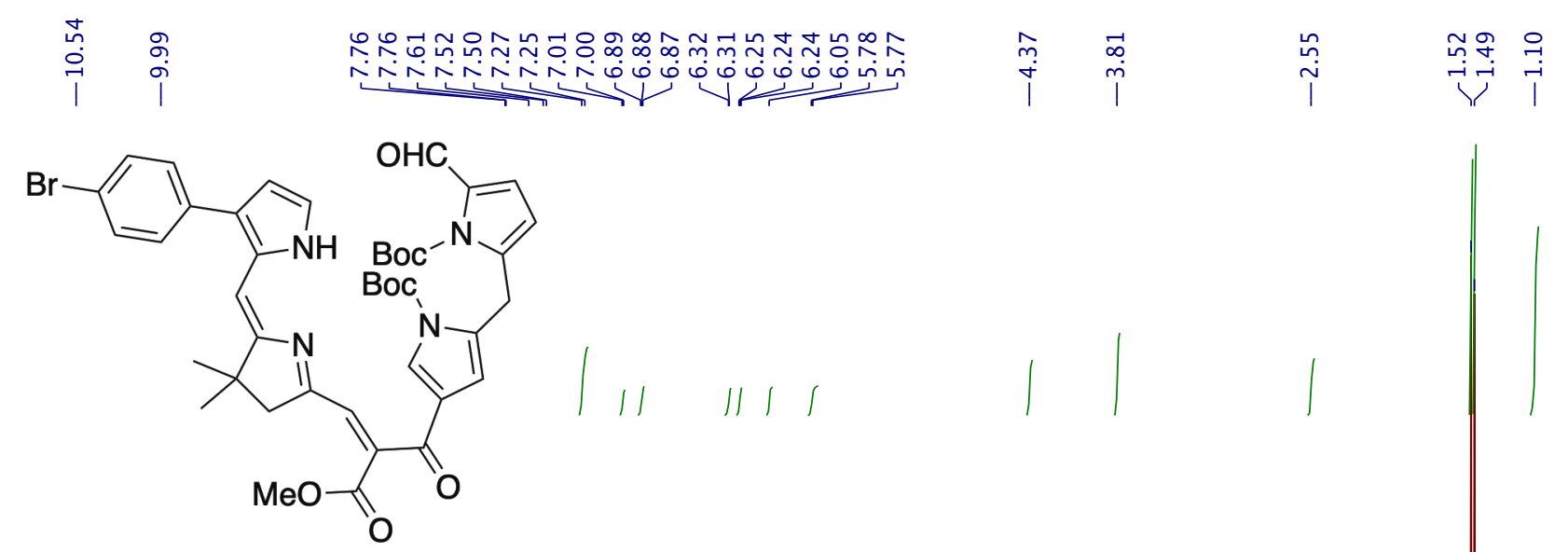

(Boc) $)_{2}-20$

(Putative Z-configuration)

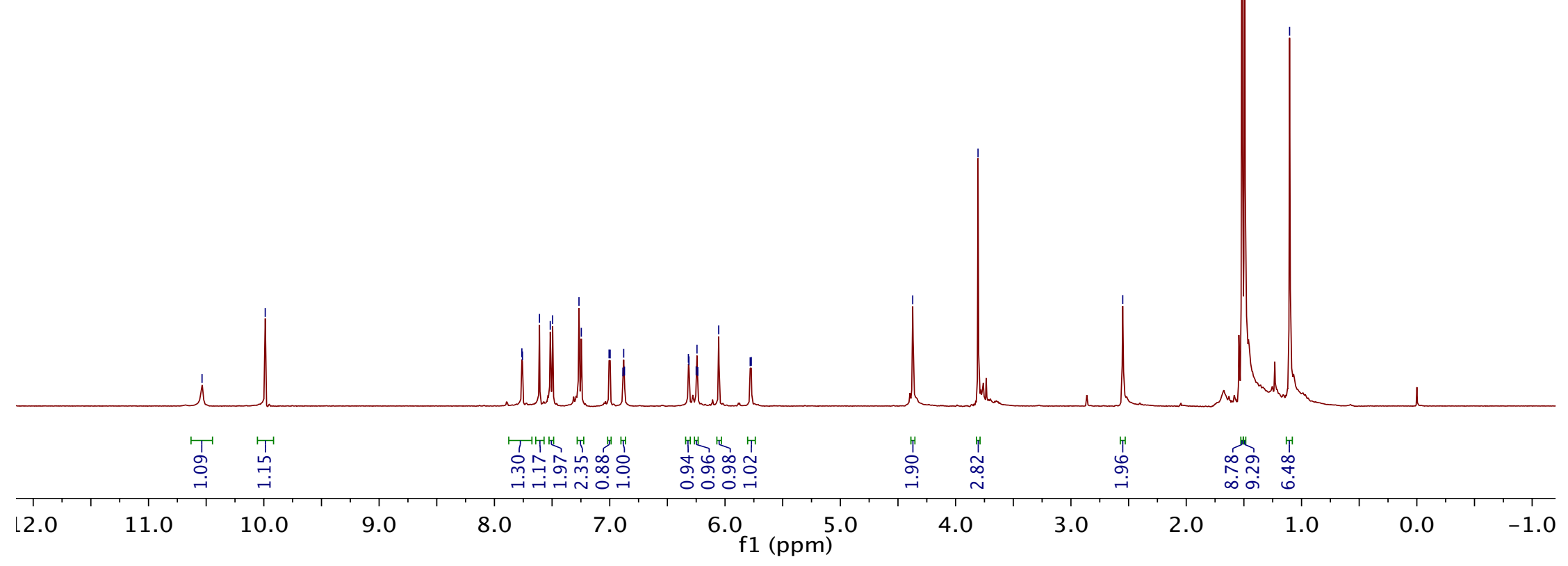




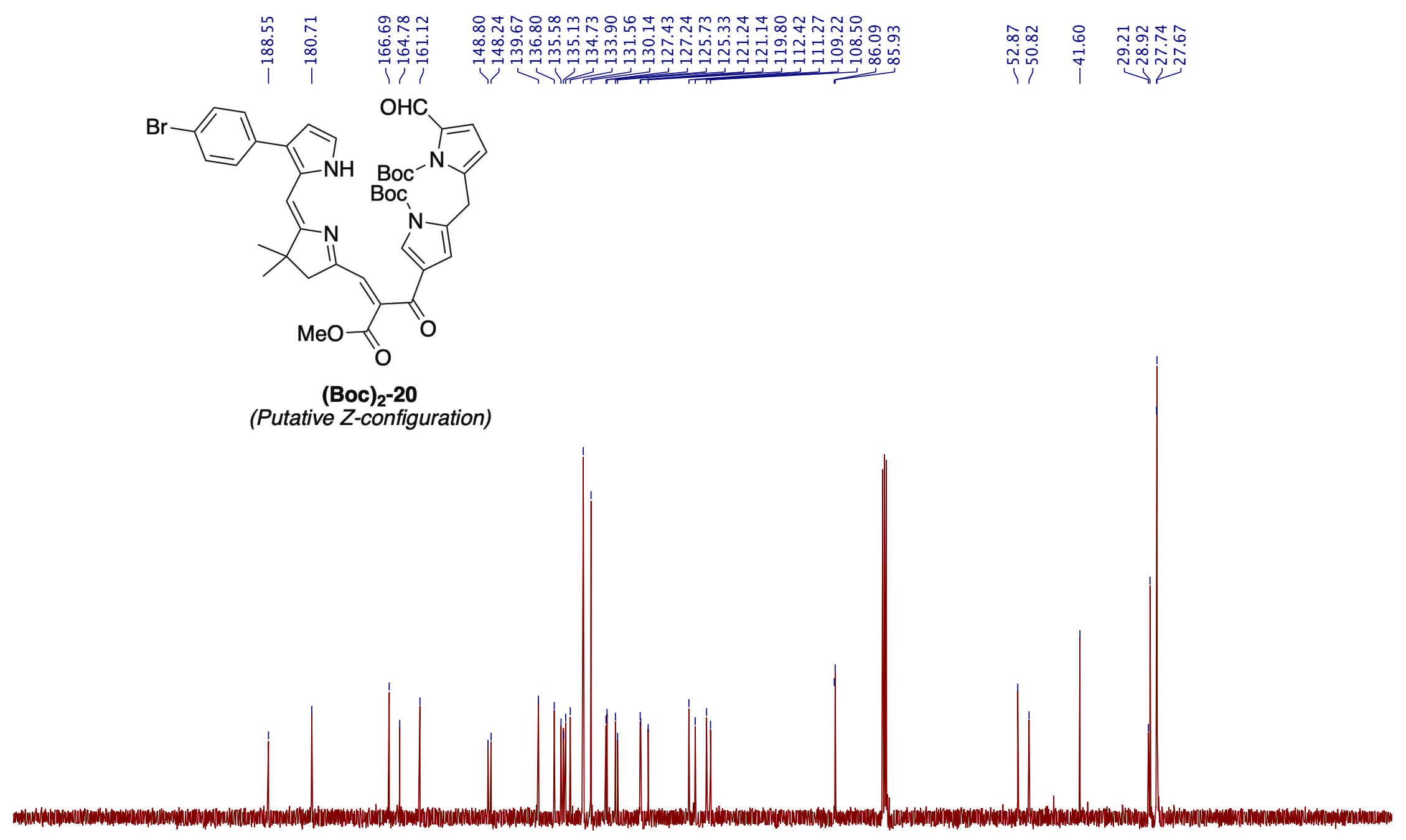

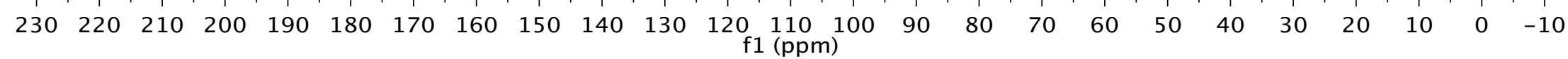




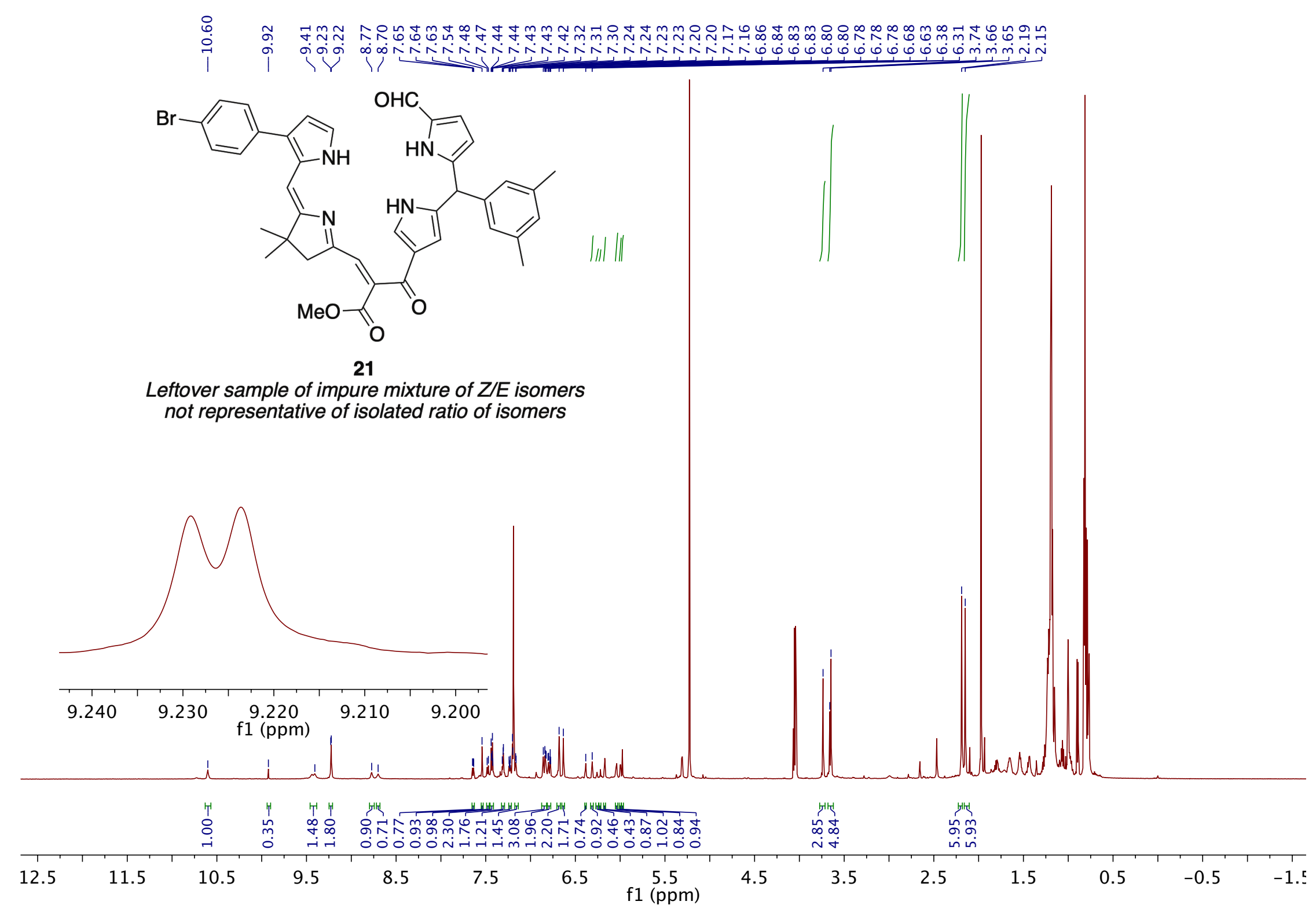




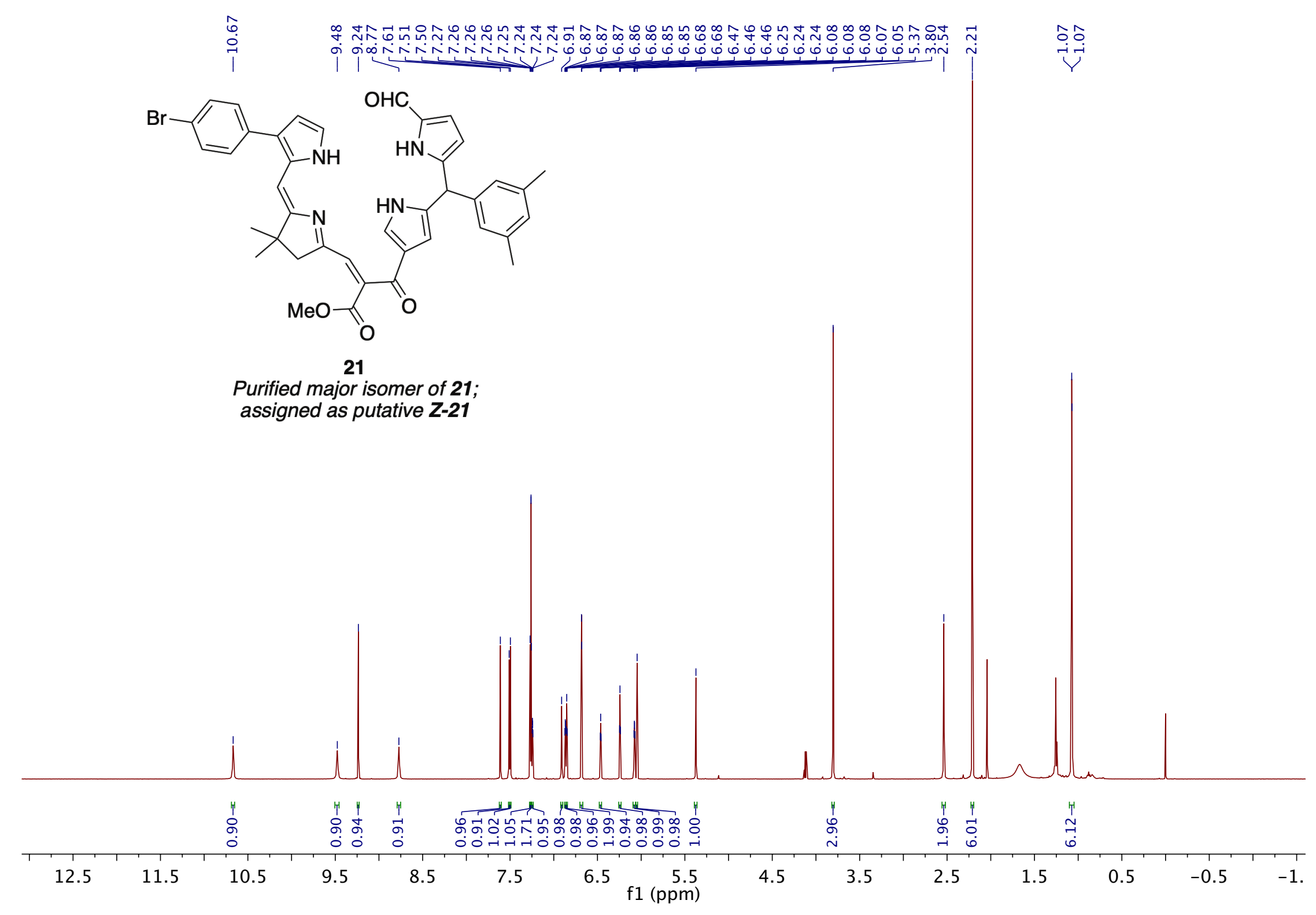




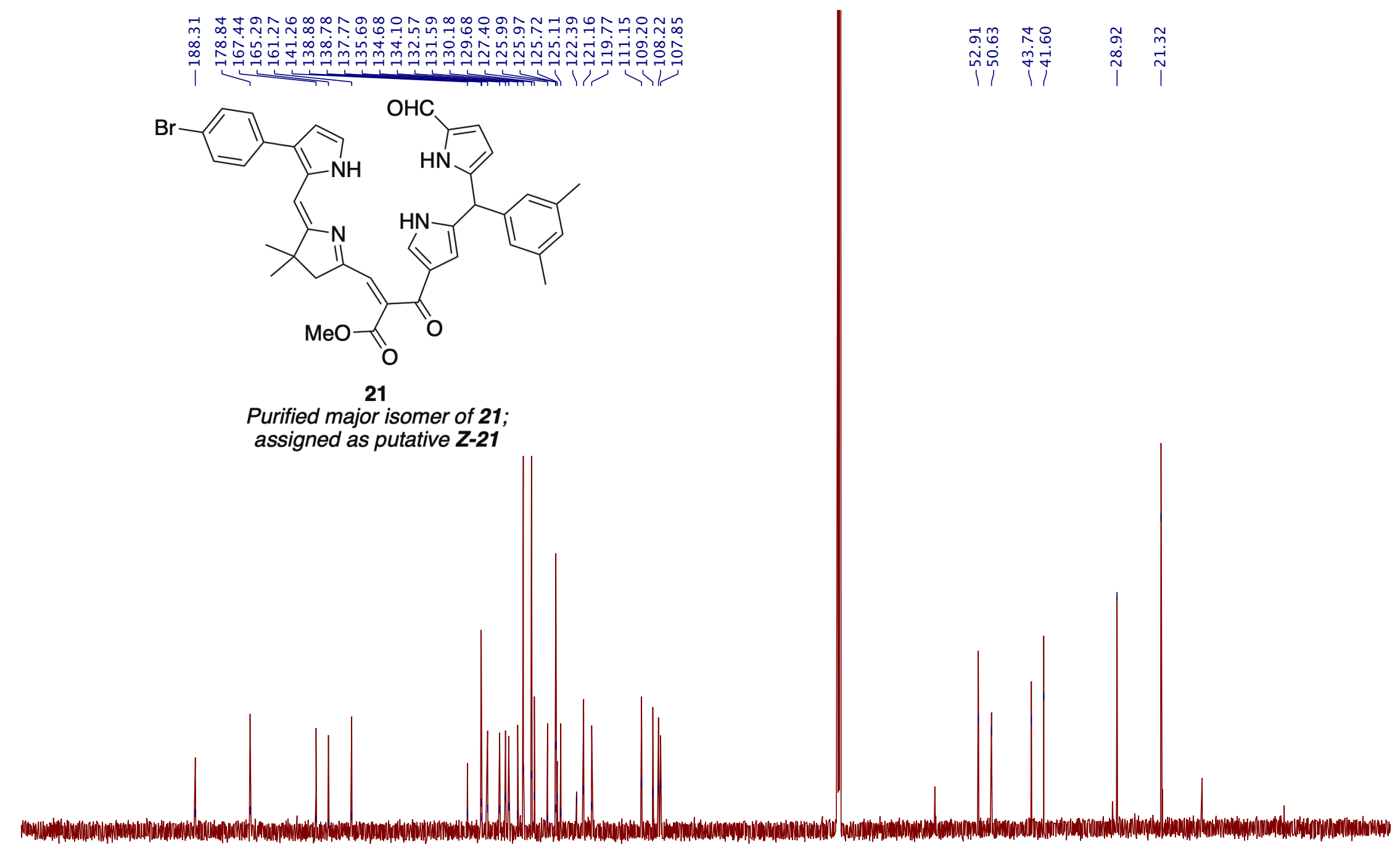

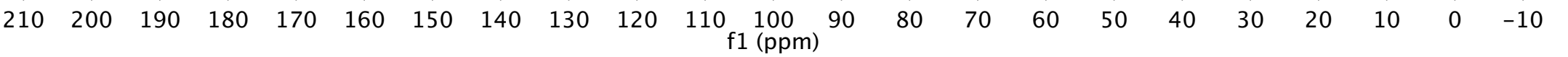




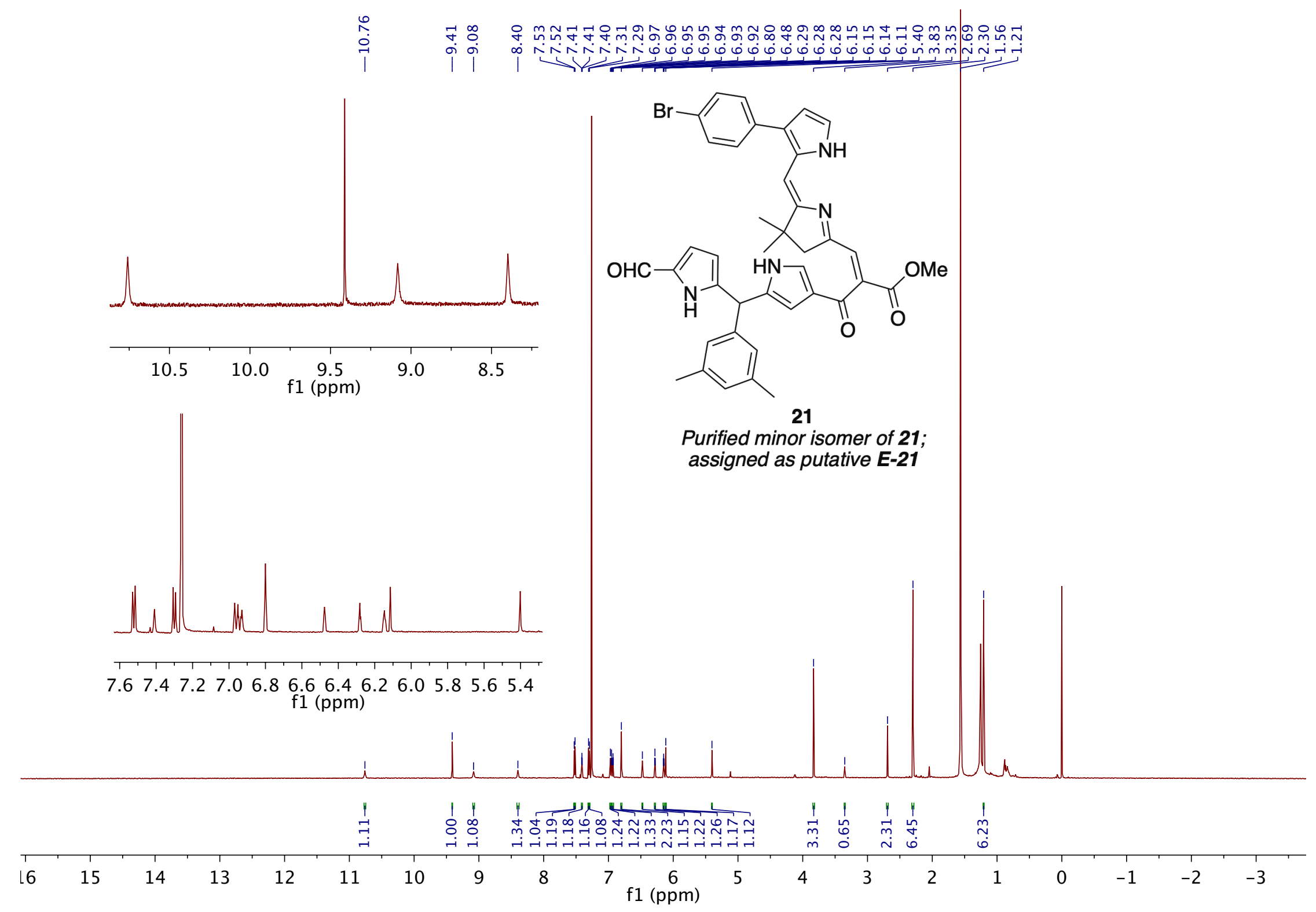



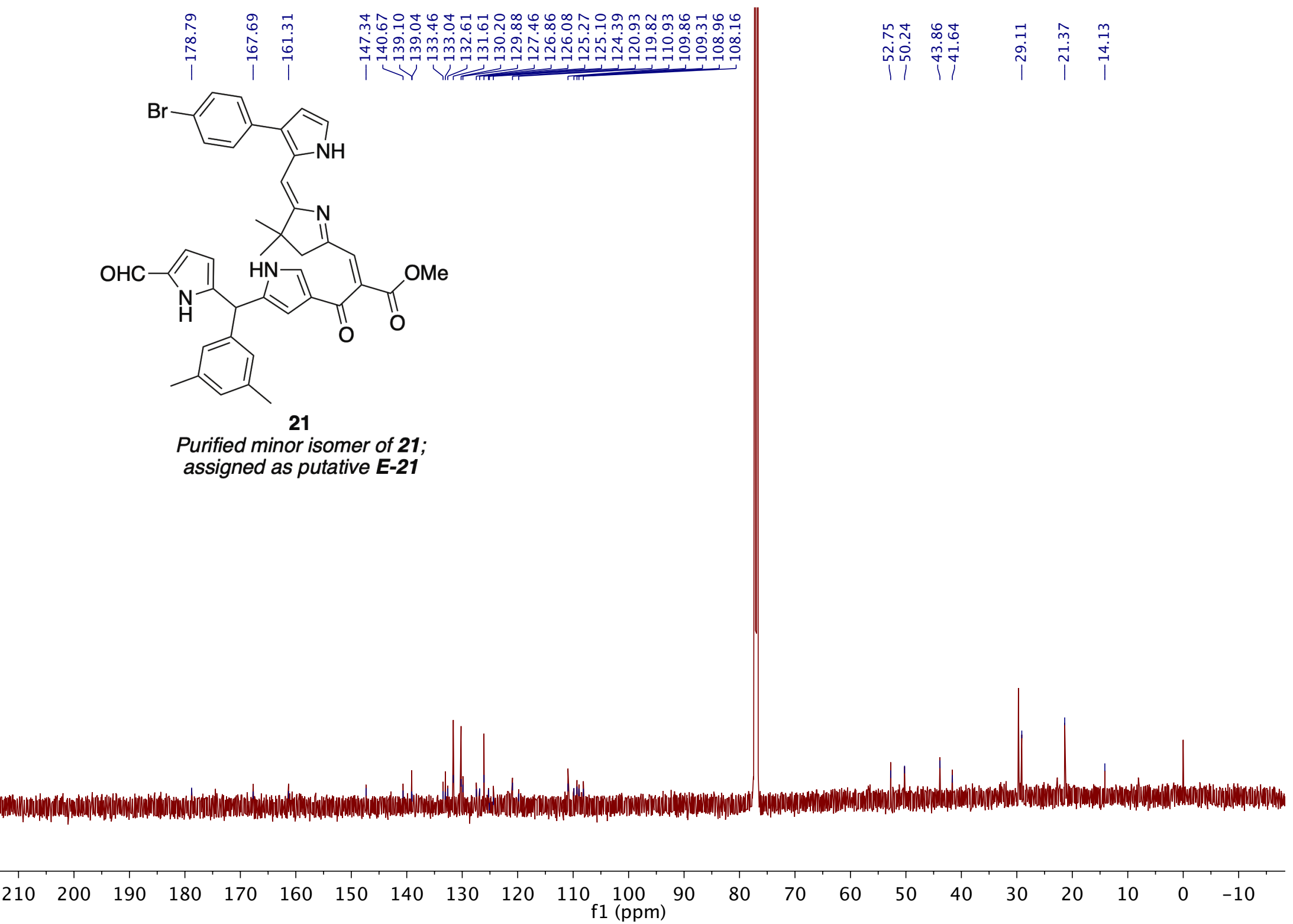


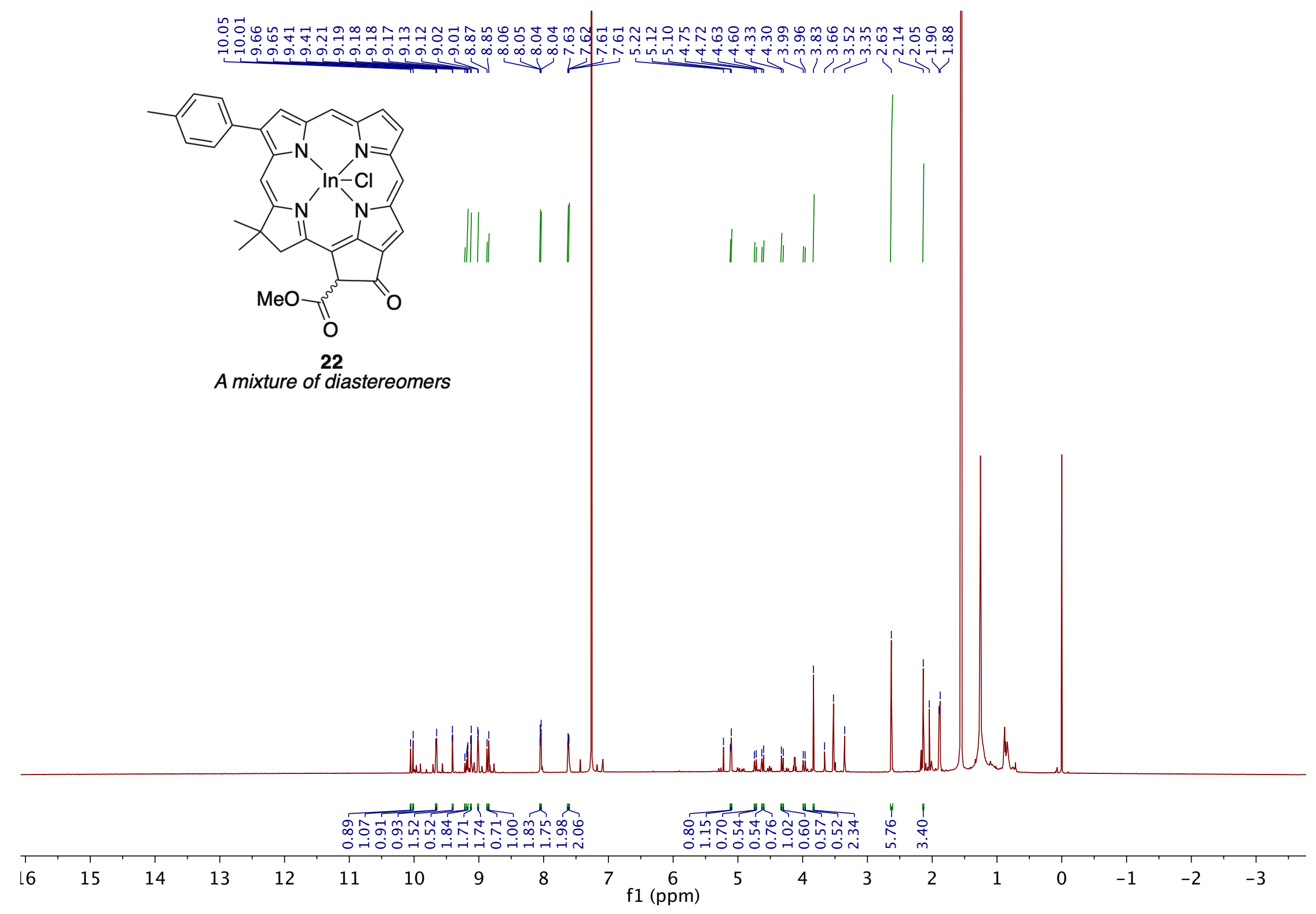




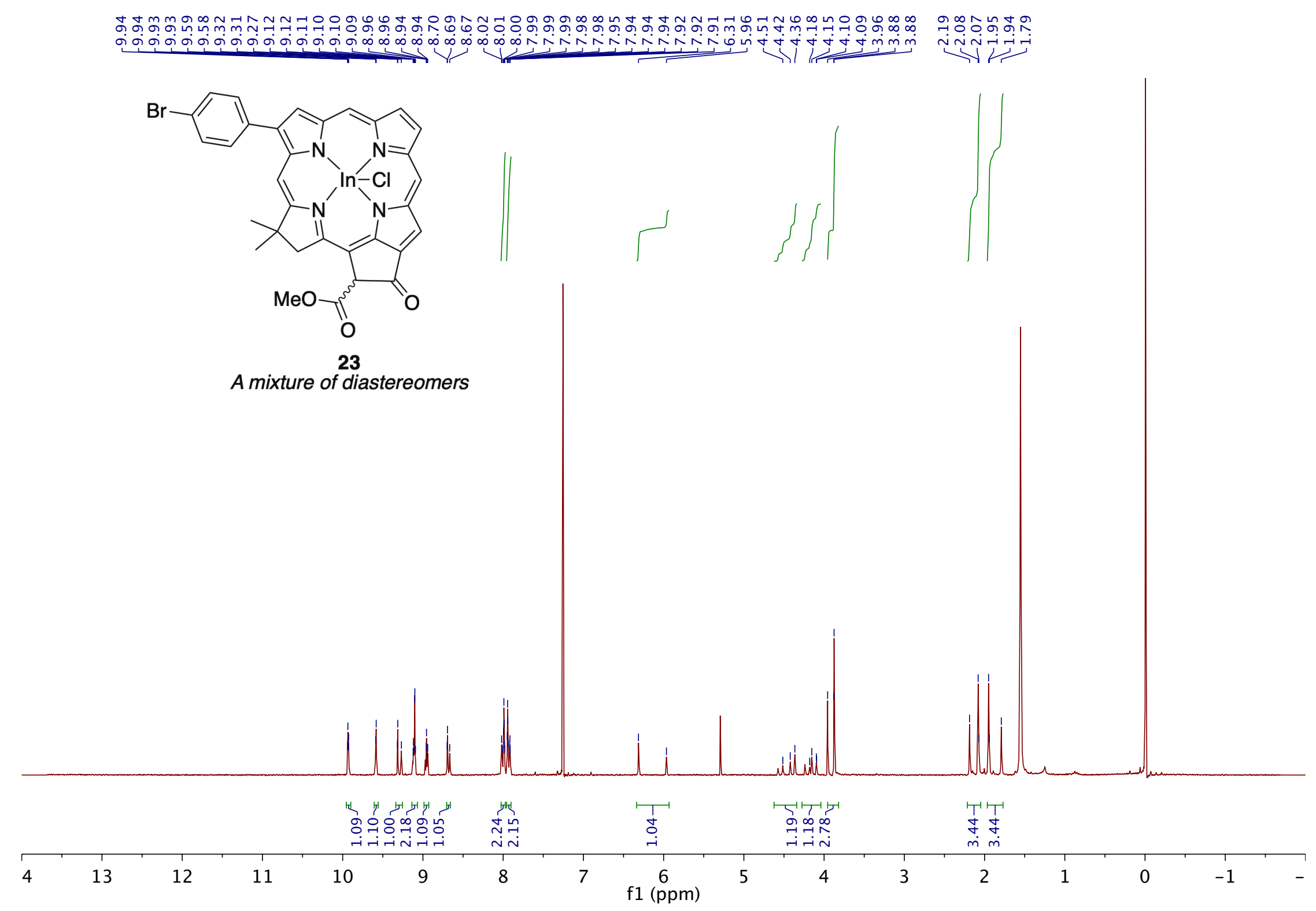




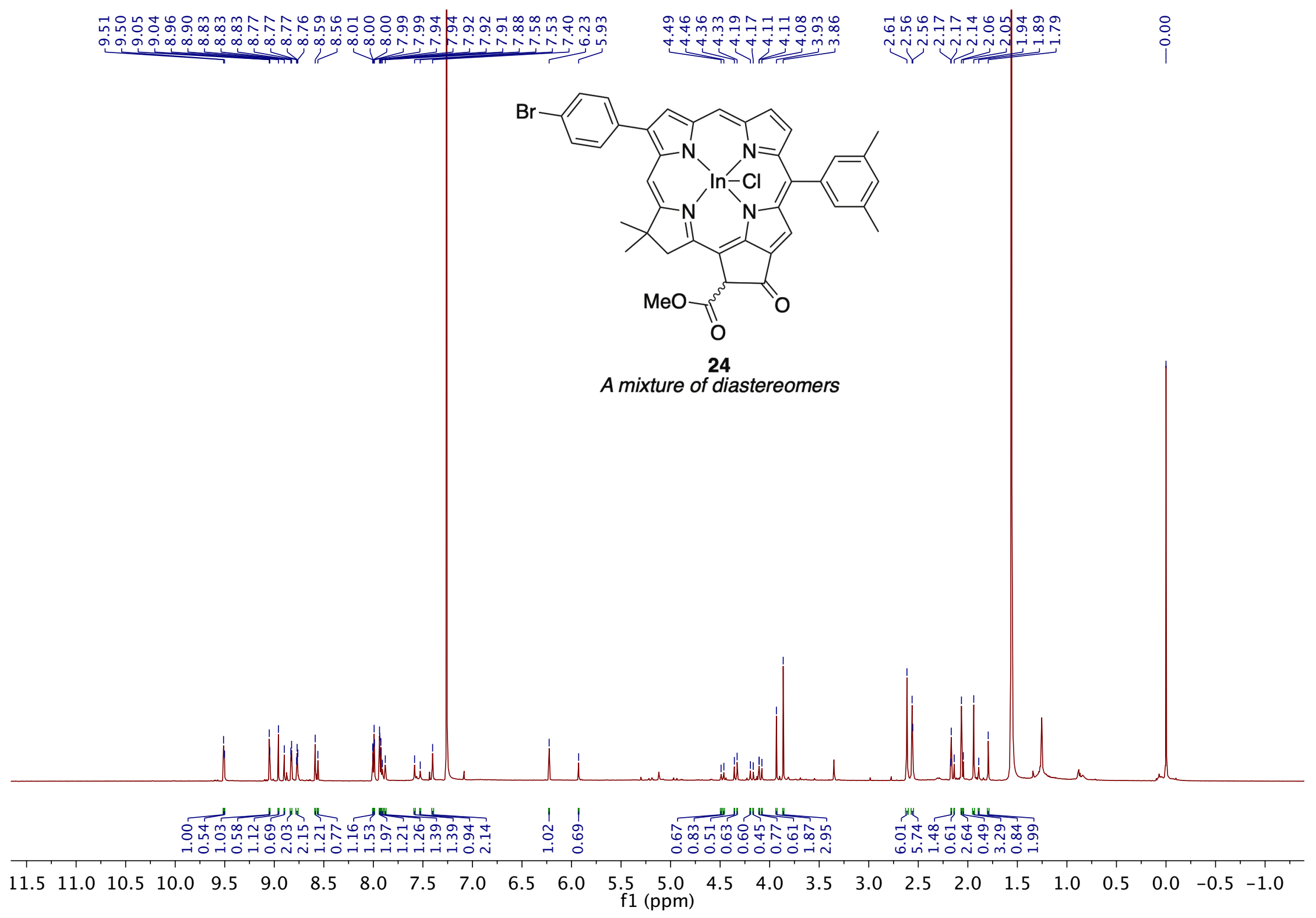




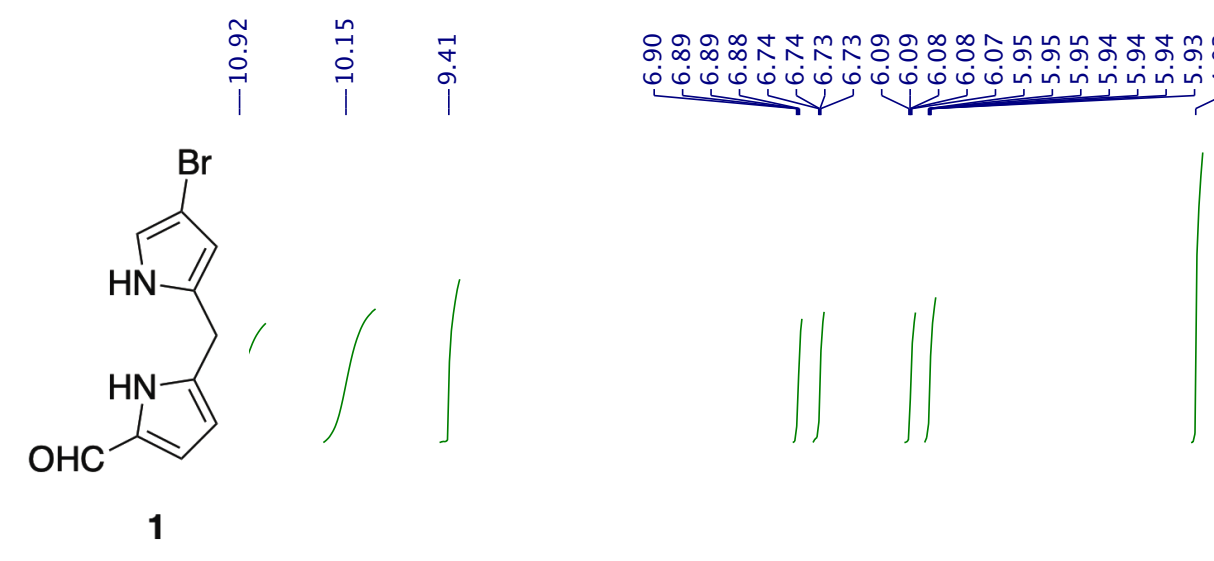

Acetone- $d_{8}$

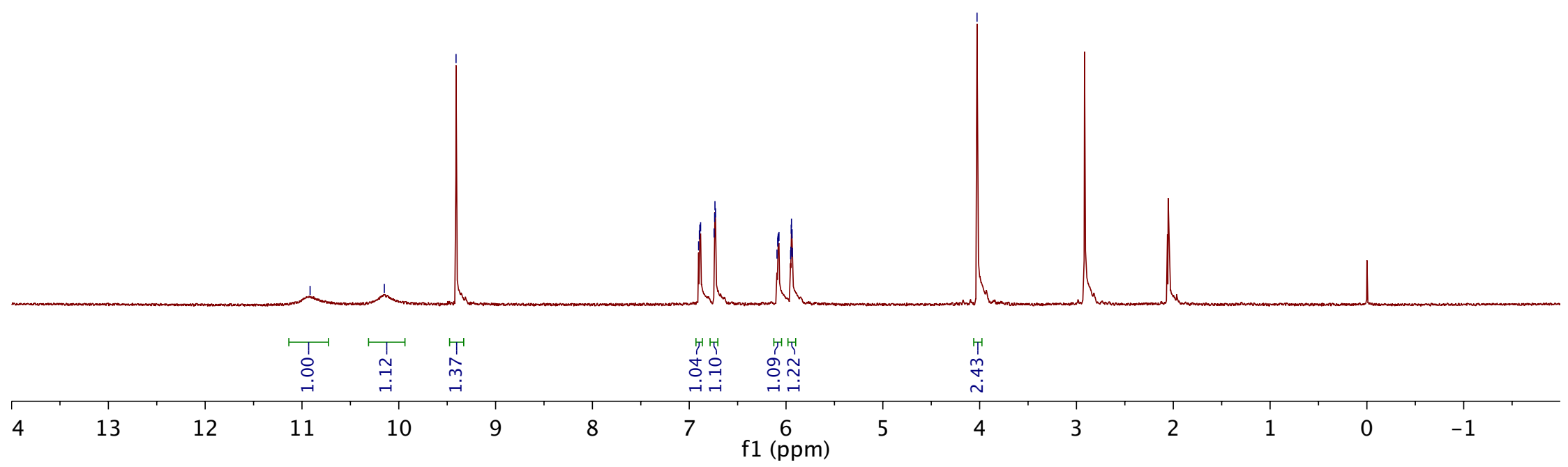


<smiles>C=CC(=O)C(OC)OC</smiles>

3a

\section{$\operatorname{san} 10$ naso}

futal-2

ata collocted oa

-

rehivo direotory

Aherdate

futal-2_20170511

111_01

Fiarile: proson

Mulse sequence: pmonos (a2pul)

Solvent! cele13

Data eollected on May 152017

Operator: 21ndeey

nelax. Aolay 1.000 aoc

Pulso 45.0 degrees

noq. time $1.706 \mathrm{sec}$

width 4803.1 II:

8 repotitions

onskavs mi, 300.1683395 nar:

DuTA Pשockssm

7) a1zo 16304

Total timo ols 22 aec
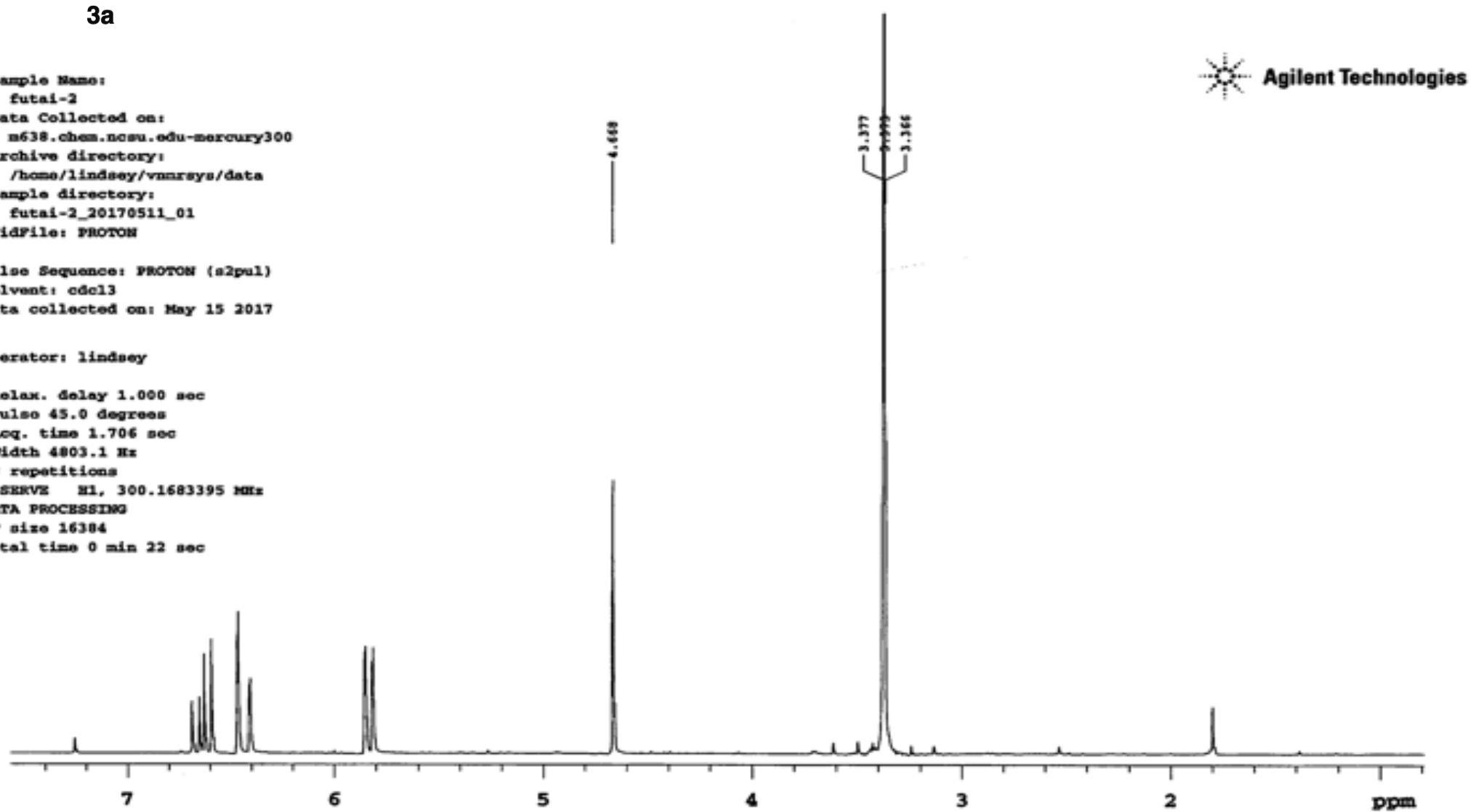


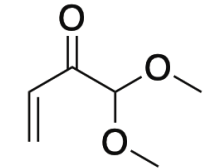

$3 a$

sanplo stane:

futa1-2

Data Collected on

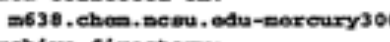

archive directory:

futa1-2_20170511

FidPi101 CarBon

Pulae sequance) CNRDON (B2pul)

Solvant: ode13

Data collected on: May 152017

Oparator: 1inda कै

polax. 401ay 1 fै

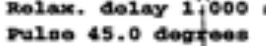

acq. timo 0.866 ace

wiate 18867.9 as

256 repetitione

OAssarve C13, 75.4773890 $\mathrm{KoH}$

DBCOUPLII 111. 300.1698745 ver=

Dowar 36 dis

contrimounaly on

wailzz-16 modulat

DATA PR०czssmo

$0.5 \mathrm{~Hz}$

Total tieo stn 1 aoc

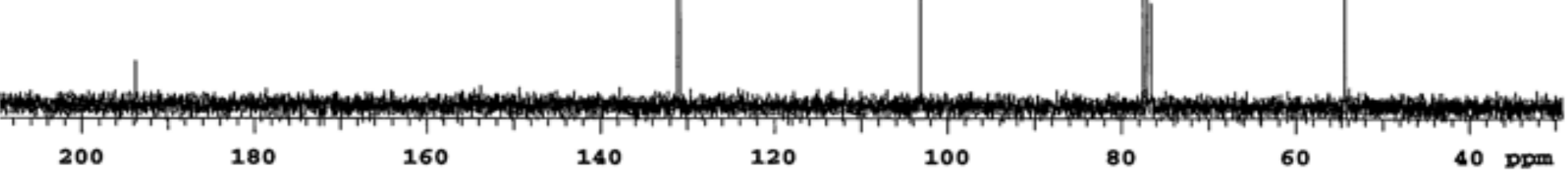




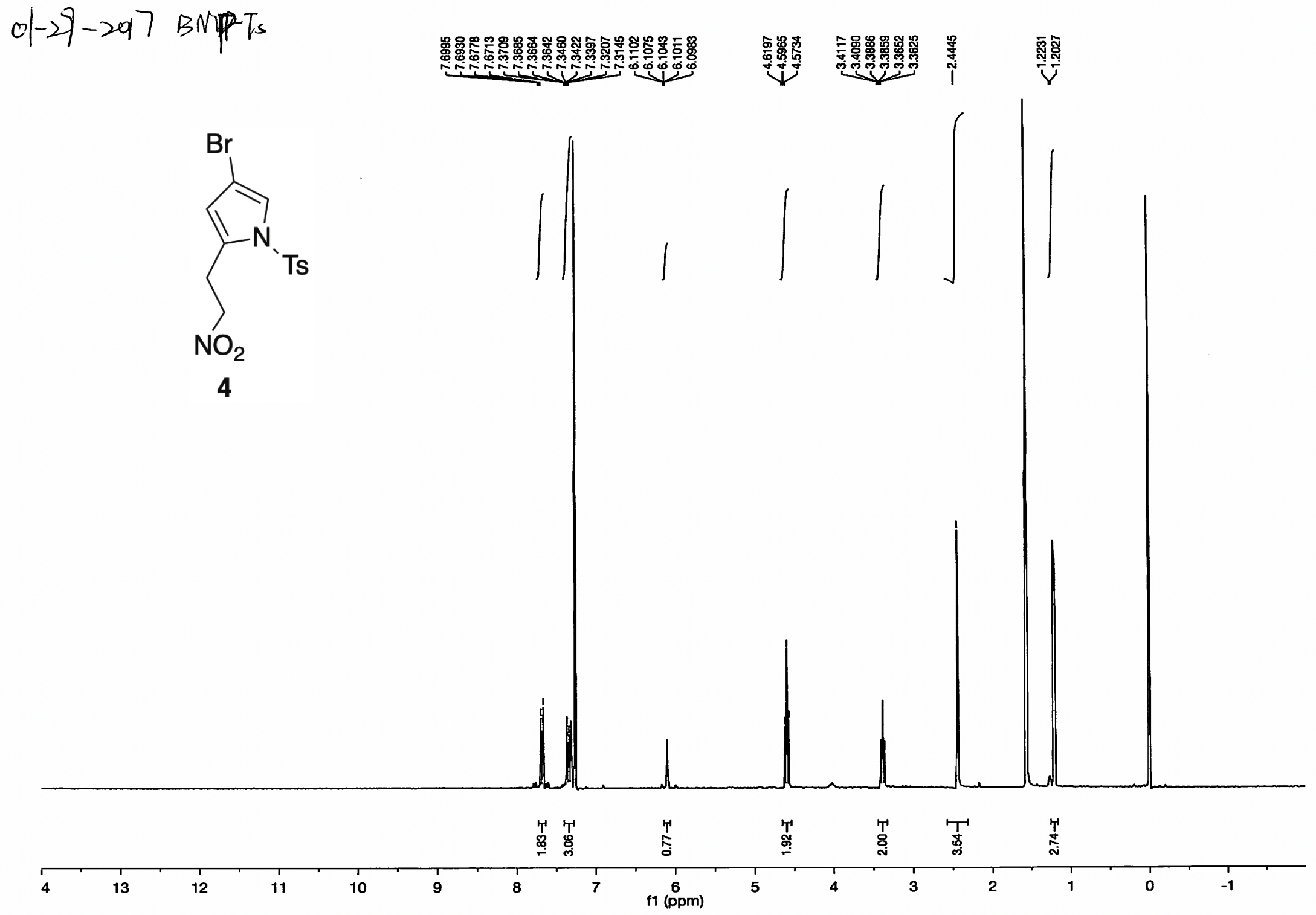




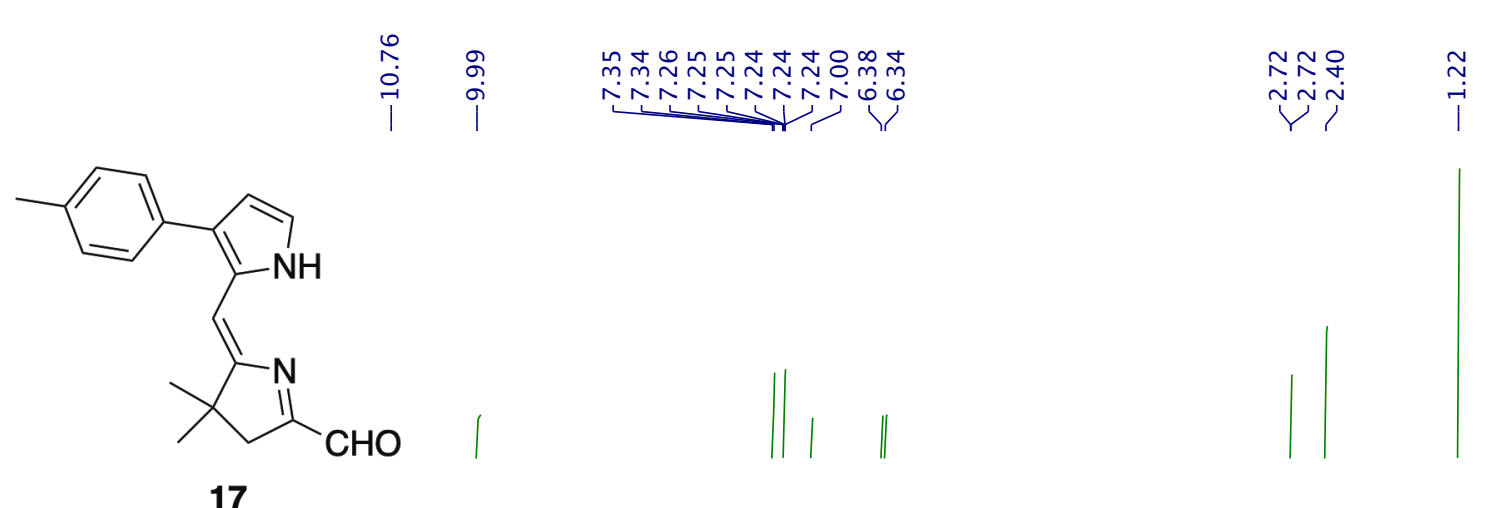

17

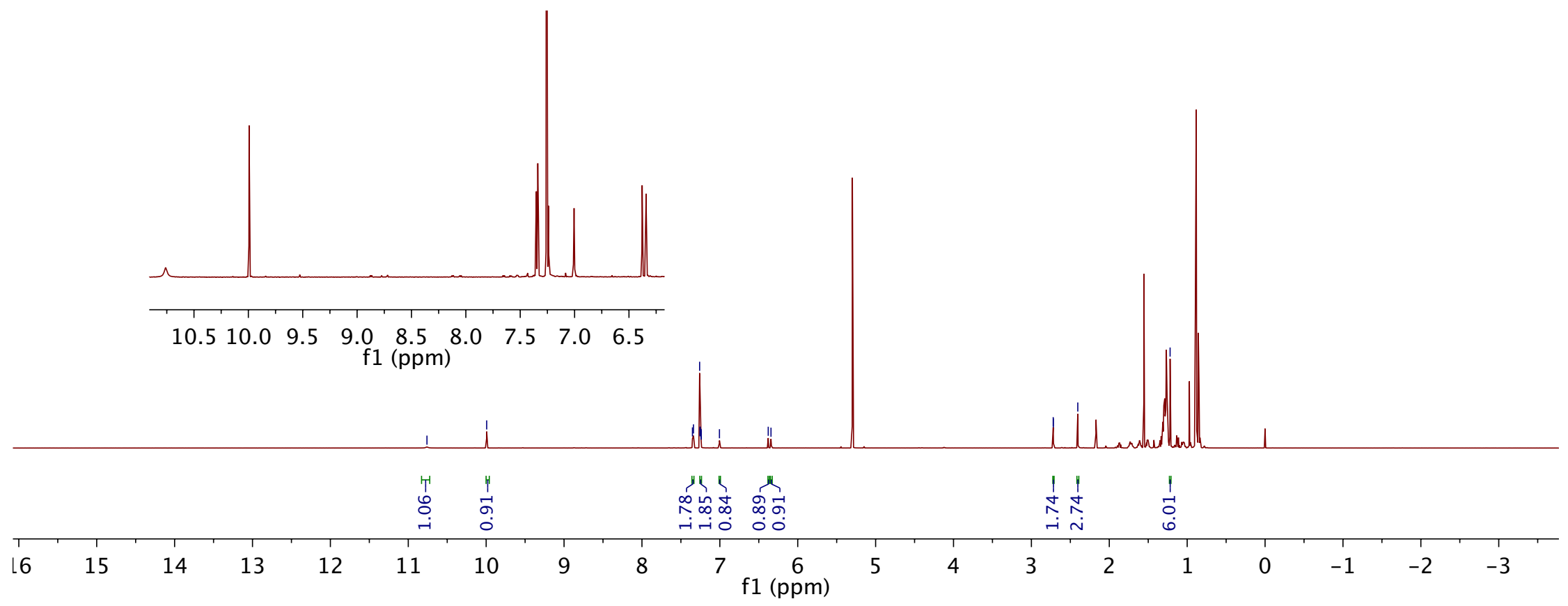




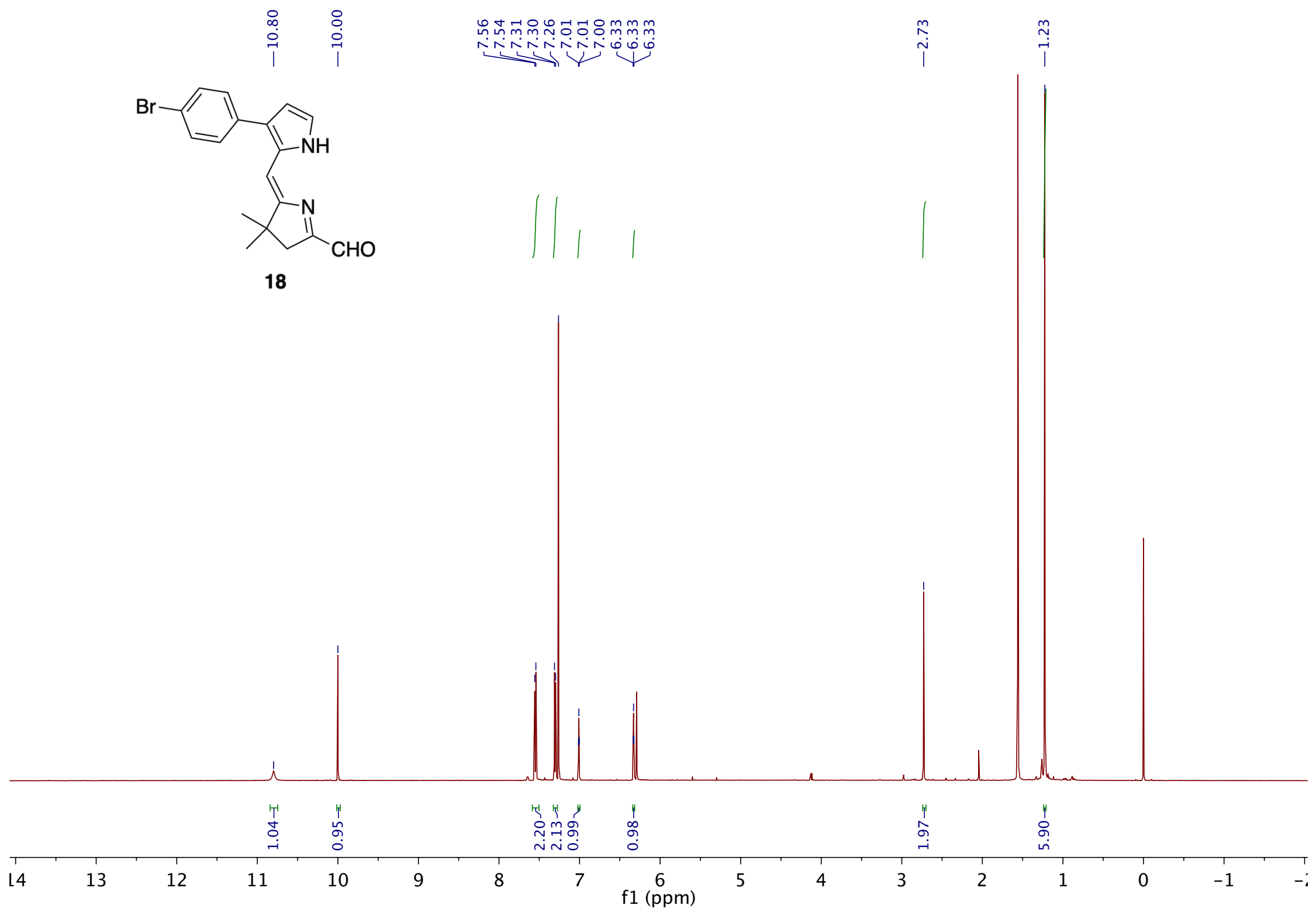

S90 